University of Louisville

ThinkIR: The University of Louisville's Institutional Repository

Electronic Theses and Dissertations

8-2008

\title{
"I had always been opposed to colonialism" : President Harry S. Truman and the end of European colonialism.
}

Timothy J. Pifer 1957-

University of Louisville

Follow this and additional works at: https://ir.library.louisville.edu/etd

\section{Recommended Citation}

Pifer, Timothy J. 1957-, "'I had always been opposed to colonialism" : President Harry S. Truman and the end of European colonialism." (2008). Electronic Theses and Dissertations. Paper 1139.

https://doi.org/10.18297/etd/1139

This Master's Thesis is brought to you for free and open access by ThinkIR: The University of Louisville's Institutional Repository. It has been accepted for inclusion in Electronic Theses and Dissertations by an authorized administrator of ThinkIR: The University of Louisville's Institutional Repository. This title appears here courtesy of the author, who has retained all other copyrights. For more information, please contact thinkir@louisville.edu. 
"I HAD ALWAYS BEEN OPPOSED TO COLONIALISM"

President Harry S. Truman and the End of European Colonialism

\author{
By \\ Timothy J. Pifer \\ B.S., West Virginia State, 1979

\begin{abstract}
A Thesis
Submitted to the Faculty of the Graduate School of the University of Louisville in Partial Fulfillment of the Requirements for the Degree of
\end{abstract}

Master of Arts

Department of History University of Louisville

Louisville, Kentucky

Augnist 2008 


\title{
"I HAD ALWAYS BEEN OPPOSED TO COLONIALISM"
}

President Harry S. Truman and the End of European Colonialism

\author{
By \\ Timothy J. Pifer \\ B.S., West Virginia State, 1979 \\ A Thesis Approved on
}

June 24, 2008

by the following Thesis Committee:

Thesis Director 


\section{ACKNOWLEDGEMENTS}

First, I would like to thank my thesis director and advisor, Dr. Benjamin Harrison for his assistance and help in selecting a little researched topic about Truman's Presidency. His guidance helped lead me in directions that I might otherwise have missed. I would also like to thank the world's most wonderful wife and my best friend, Nancy, for her amazing proofreading which rendered my writing legible to the rest of the world.

Moreover, I want to thank her for the endless patience and encouragement she displays for anything I set out to do. Lastly, I want to thank my parents, Jim and Phyllis Pifer, who told a young boy in West Virginia that an education was the most important thing in the world. Without your love and support this paper might never have been. 


\begin{abstract}
"I HAD ALWAYS BEEN OPPOSED TO COLONIALISM"

President Harry S. Truman and the End of European Colonialism
\end{abstract}

Timothy J. Pifer

August 7, 2008

This thesis is a biographical and historiographical examination of Truman's rhetoric and handling of colonialism. Truman's position regarding European colonialism is a worthy topic since it facilitates the study of the United States' treatment of people in underdeveloped countries and allows insight into Truman's beliefs. The research methodology and references used for the paper include primary sources drawn principally from the Truman Presidential Library as well as numerous secondary sources relating to Truman's Presidency.

The focus of analysis is on Truman and his administration's oratory and diplomatic decisions regarding colonial issues. The findings show that Truman demonstrated through both his public and private communications that he opposed colonialism. Furthermore, the bulk of the foreign policy decisions made by Truman's administration showed a tendency to oppose colonialism. Nonetheless, Truman aided French efforts to reestablish control over former colonies in Indochina and this deviation undermined his otherwise anti-colonial legacy for future generations. 
ACKNOWLEDGEMENTS iii ABSTRACT iv

CHAPTER

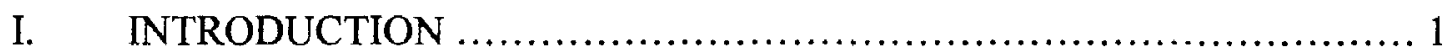

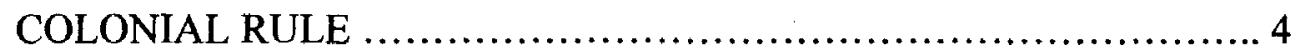

II. HISTORIOGRAPHICAL REVIEW ..................................... 7

III. FRANKLIN D. ROOSEVELT / WORLD WAR TWO ................... 31

IV. HARRY S. TRUMAN ............................................. 46

EARLY PRESIDENTIAL PHILOSOPHY ............................ 46

FDR / HST DIFFERENT PERSONALITIES ........................ 48

WILSONIAN FOREIGN POLICY ................................... 51

ANTI-IMPERIALSIM .............................................. 52

TRUMAN'S ADVISORS ............................................. 57

TRUMAN'S VIEW OF THE STATE DEPARTMENT .................. 59

TRUMAN'S SECRETARIES OF STATE ........................... 63

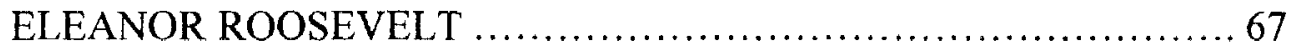

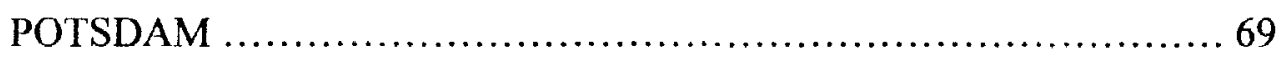

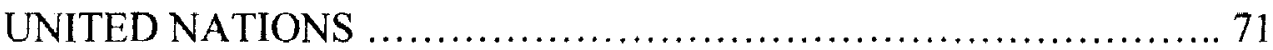

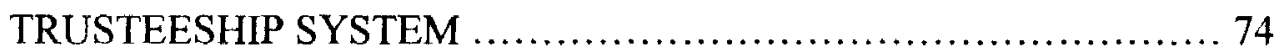


COLD WAR / SHIFTING POLICIES ............................ 83

WINTER 947 / A WEAKENED BRITAIN AND EUROPE ............ 84

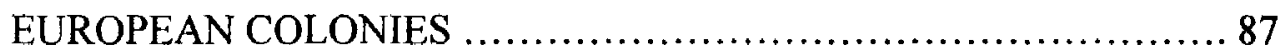

BIPOLAR WORLD ............................................... 92

LATER TRUMAN POLICIES .................................... 96

INDIVIDUAL EUROPEAN EMPIRES .............................. 98

Great Britain ................................................... 98

Netherlands .................................................. 101

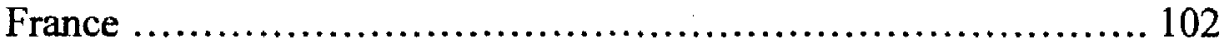

V. CONCLUSION .................................................... 108

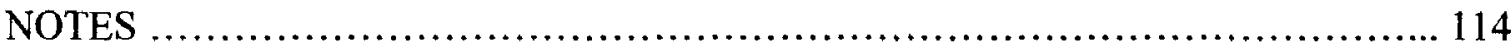

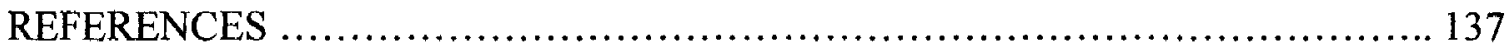

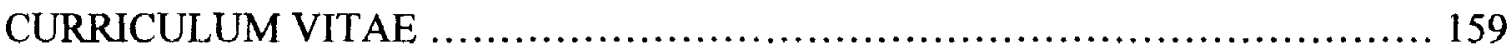




\section{CHAPTER I}

\section{INTRODUCTION}

The primary objective of this paper is to provide a biographical and historiographical examination of Harry S. Truman's (HST) leadership on the issue of European colonialism during the earliest period of the late twentieth century global contest called the Cold War. Truman's stance on European colonialism is a worthy topic of examination since it facilitates an understanding of actions undertaken by his administration and allows insight into the complex character of Truman. This understanding remains relevant since the ramifications of the Truman White House's actions regarding former colonies at the end of World War Two still impact people in Asia, the Middle East, Africa and other parts of the world. Equally important, a grasp of Truman's actual or de facto policy on colonial rule is critical to any historical study of the United States' treatment of the people in underdeveloped countries. This paper seeks to answer the following questions: Did Truman have a consistent foreign policy on the issue of Europe's external colonies? Did Truman consider European control of underdeveloped countries as natural or did he see it as exploitation of native peoples? Did he ever touch on the issue of colonial rule in public speeches or private correspondence? Lastly, did his private beliefs coincide with his administration's practice of foreign affairs? 
This paper considers these questions and suggests that Truman was hostile to any form of colonial rule, including the variety practiced by the major powers of Europe. The thesis of this paper is that Truman demonstrated through both his public and private communications that he opposed colonialism. Furthermore, the bulk of the foreign policy decisions made by Truman's administration showed a clear tendency to oppose colonialism. Nonetheless, Truman aided French efforts to reestablish control over former colonies in Indochina and this deviation undermined his otherwise anti-colonial legacy for future generations.

The paper examines the following ideas in order to validate the thesis. First, that Truman stated while in and out of office that he opposed the concept of empires ruling other lands and peoples. He made the point that colonialism was contrary to his basic beliefs and his personal values as an American. Furthermore, Truman's anti-colonial stance mirrored the position of the late Franklin D. Roosevelt (FDR) who had held a deep-seated opposition to European colonialism, particularly as practiced by the British Empire. Another facet to consider was that Truman's attitude also seemed to reflect the American ideal of free trade across international borders and the unfettered movement of capital. Truman's stand against colonial governance remained firm though later in his administration it evolved into a form that would fit with his anti-Communist language.

Second, while Truman personally opposed colonial control his administration's foreign policy approach lacked consistency. At the beginning of his tenure, Truman's rhetoric took aim at empires and their involuntary control of other regions of the world. Simultaneously, the nation's foreign policy opposed European colonialism and included this worldview into the foundation of the new United Nations in the form of trusteeship. 
However, over time, Truman and his key people's bureaucratic strategy evolved in such a way that they ended up supporting the European powers, and their imperial systems, which they had previously opposed. The paper will show the basis for this turnabout was another foreign policy concern, the growing fear of a new imperialism in the guise of the Union of Soviet Socialist Republics (USSR).

The research methodology and references used for the paper include primary and secondary sources related to the questions about Truman and postwar colonialism. The focus of the analysis is on the administration's assessments and incentives concerning colonial issues within the context of the major foreign policy themes of the day, namely the post-Second World War global instability and the onset of the Cold War. Another focal point of the analysis is Truman's personal and public position on colonialism and the impact that had upon the overall administration's policy. The Truman Presidential Library \& Museum's archives in Independence, Missouri provided the bulk of primary sources used in this analysis. The library resources include Presidential copies of estimates and intelligence reports from the Central Intelligence Agency (CIA), the National Security Agency (NSA) and the State Department. The library's vast collection of oral interviews provided personal observations from people involved with, or influenced by, the Truman administration's various strategies and conceptual planning efforts. Truman's own words were available from his memoir drafts, copies of speeches, logs from press conferences, and private letters. In addition to the material from the Truman Library, period news articles, books published during that time and shortly after Truman left office, and Dean Acheson's published memoir round out the primary sources. Secondary sources relied first upon Truman biographies, such as Robert 
Ferrell's Harry S. Truman: A Life, ${ }^{\prime}$ Alonzo Hamby's Man of the People: A Life of Harry

$\underline{\text { S. Truman }}{ }^{2}$ and David McCullough's Truman $^{3}$ for contextual information on the man and the times. Building upon this foundation was the examination of a number of Cold War histories and several existing academic theses, relating to the Truman administration, the United States' involvement in Vietnam, colonialism and decolonization in the postwar period. These primary and secondary sources provide an examination of Truman, the man, and Truman, the President, during a transitional administration, which oversaw the passing of the old European order and the development of a new equilibrium in foreign affairs.

\section{COLONIAL RULE}

Before proceeding further, the following discussion will help establish a common definition of colonial rule as applied to Truman's position on the issue of European colonialism. First, the terms colonialism and imperialism are interchangeable for the purpose of this paper when discussing the postwar European empires. ${ }^{4}$ A 1972 article on cultural geography by Michigan State Professor Ronald J. Horvath says "It seems generally... agreed that colonialism is a form of domination-the control by individuals or groups over the territory and/or behavior of other individuals or groups. (Colonialism has also been seen as a form of exploitation, with emphasis on economic variables ...).".5 Thus, this definition would include the safeguarding of closed markets and natural resources from outside nations as described by the popular historian and prolific author 
Walter LaFeber. ${ }^{6}$ The system used by the European powers at the end of the nineteenth century was one of extracting natural resources from the colonies, using that material to produce manufactured products and then selling those goods back to the colonies or to other nations. This system involved a large portion of the world's population and the European nations who had empires were especially active in the arena of world affairs.

What today may seem like an archaic and outmoded system did not seem so antiquated in the mid-twentieth century. During this period, the European empires controlled over twenty percent of the world's land mass and a large share of the world's economy. ${ }^{7}$ Despite the large geographic areas concerned, the colonial control, or imperialism, practiced by the Europeans involved few settlers from the homeland residing permanently in the colony. Nevertheless, the European nations wielded almost unlimited control over the governmental and economic affairs of their colonies by means of an imperial administration managed from the motherland's capital in Europe or England. ${ }^{8}$ This external control over the colonies' indigenous people also increased the power of the European nations in ways other than economic. One example was the use of colonial troops in both World Wars to augment the European nations' power. The additional work force available to the European combatants is one reason the conflicts were able to go global. ${ }^{9}$ Other aspects that increased the empire's power included the ability to base land and naval forces around the world, which increased the global influence of the Europeans. Moreover, the historic rivalries that existed between the European empires produced tensions that increased the odds of direct confrontation. Since the colonies caused these clashes, and provided the men to fight them, they, in turn, would be a factor in any foreign affair equation. ${ }^{10}$ 
From the end of the First World War to the end of the Second World War, the colonial empires of Europe were at their most extensive and covered a large part of the globe. ${ }^{11}$ The British Empire had by far the largest group of colonies and its size recalls the wellknown adage; "an empire on which the sun never sets." 12 In fact, by the end of the Second World War the British Empire and Commonwealth included more than sixty nations around the world. ${ }^{13}$ Even in the economically troubled period after the Second World War the Britain Empire was still important, producing worldwide “. . almost a quarter of all manufactured exports in 1950." "F For these reasons when the United States government focused on the subject of colonialism in the $1930 \mathrm{~s}, 40 \mathrm{~s}$ and $50 \mathrm{~s}$, they were normally looking at the colonies of the British Empire. 


\section{CHAPTER II \\ HISTORIOGRAPHICAL REVIEW}

The foreign affairs focused historiographical interpretation of the larger field of Cold War history is well established. Throughout the various accounts of the Cold War, the central question has been; which faction was primarily responsible for the development of the conflict? The answer to this query has resulted in different schools of thought. Historians Arthur Schlesinger, Herbert Feis and Louis Halle gave rise to the first school's interpretation. ${ }^{1}$ Their belief was that during the early postwar period, before the start of the Cold War, the United States' foreign policy was passive in nature ${ }^{2}$ and focused on efforts such as the establishment of the United Nations' trusteeship program. This early school maintains that despite the United States' best efforts to befriend the Russians, the USSR-United States conflict was unavoidable. This traditional view also argues that the Soviet Union precipitated the Cold War because of their aggressive attitude and empire building. These ideas were dominant until the late 1950s and the advent of the Vietnam War. Younger historians then started to disagree with that analysis and began to place the blame in large part on America's efforts to establish a United States-friendly world economic hegemony. William Appleman Williams ${ }^{3}$ led the newer school of thought and its champion was Walter LaFeber. ${ }^{4}$ This school's analysis argues that the Russians were too weak after the Second World War to be a credible threat to the United States and 
therefore could not have drawn the United States into the Cold War. These Cold War revisionists also portray the Roosevelt and Truman administrations as less than committed to universalism, the idea that nations should work together for the common good of humanity. Instead, the revisionists assert that the motivation for both administrations was self-interest and that they pursued their goals at the expense of other nations. ${ }^{5}$ A later group of historians, led by John Lewis Gaddis and sometimes described as the Post-revisionism school, proposed yet another interpretation of events. ${ }^{6}$ Gaddis' view is, in some ways, a blend of the previous schools with America's world economic hegemony efforts being more benign and defensive in nature rather than domineering. ${ }^{7}$ This latest school seeks to establish a balance and places the blame for starting the Cold War on both the United States and USSR. Moreover, Gaddis points out that, for one, FDR placed the winning of the war and protecting the postwar alliance above all other foreign policy considerations to include anti-colonialism. ${ }^{8}$ These schools of thought also include other suppositions on the nature of the Cold War but the theories described here seem to be the most relevant to the subject of colonialism and America's subsequent foreign policy.

No unified body of work or specific school of study exists that analyzes Truman's position on the issue of colonialism. Therefore, it is impossible to ascertain cohesive trends or contrasting theories based on exclusive publications concerning Truman and colonialism in the postwar era. Instead, this historiographical analysis draws from literature concerning the period, associated subjects, and people that were involved in the ongoing events. This analysis groups together related books and articles to allow the review of theories and trends that may be occurring throughout the literature. This 
historiographical review begins with a focus on Truman and the published works highlighting his life.

The review begins by focusing on an examination of some of the foremost and bestknown Truman biographies to gain an understanding of how Truman's administration related to European colonialism and to look for clues regarding his personal stance on the subject. Overall, these biographies provide similar accounts concerning Truman's attitudes though they offer varying perspectives on parallel events. McCullough's mainstream biography is typical of the others in the sense that he does not deal directly with the issue of Truman's personal vision of colonialism or decolonization. Rather, the popular biographer discusses the various crises and ordeals that surrounds the decay of the European empires and describes how Truman mentally approaches such problems. In particular, McCullough discusses the birth of the United Nations, some facets of the trusteeship system, and the decline of Britain. He also provides glimpses into Truman's psyche and world-view as they relate to the issue of colonialism. McCullough portrays Truman as an intelligent, though not brilliant man, and one far more complex than is recognized by the public. ${ }^{9}$ He made a key point when he noted that Truman was more a man of the nineteenth rather than the twentieth century and an individual who idolized the concept of Jeffersonian Democracy. ${ }^{10}$ However, contrary to Jefferson, who rejected the idea of entangling foreign alliances, Truman embraced the idea of the United Nations, at least in the beginning. ${ }^{11}$ Alonzo Hamby, Ohio State Professor of History wrote a biography that, like McCullough has, claimed that nineteenth-century ideology was the foundation for Truman's decision-making process. He repeatedly contends that, reputation notwithstanding, Truman was not rash in his decision-making and fully 
analyzed the input from his advisors. ${ }^{12}$ Hamby's Truman was a man who believed that "one could achieve idealistic ends by realistic means." 13 In addition, Hamby noted that Truman tended to deal with problems in the foreign policy arena as soon as they came up which, in turn, had implications for his administration's overall foreign policy. ${ }^{14}$ Emeritus Professor of History at Indiana University, Robert Ferrell's biography is different from the others in that it depicts a Truman who seems less involved in foreign affairs that delve into the issue of colonialism. Moreover, Ferrell does not examine foreign policy decisions as deeply as the other two biographers do in their books. Nevertheless, Ferrell's insights do not differ significantly from Hamby's and McCullough's instead reinforcing the point that Truman's foreign policy focus was on other issues, such as Europe's overall well-being and the power imbalances found in other regions of the world. While scant solid evidence exists in the biographies about Truman's actual opinions about colonialism, policy decisions made by his administration, as well as the insights provided his biographers, offer sufficient information to infer that Truman was ideologically opposed to the idea of imperialism.

A survey of history books covering the period also provides more insight into the Truman administration's foreign policies and decision-processes relating to the colonial issue. The vast majority of these books tend to focus on the Cold War aspect of foreign affairs to the almost total exclusion of other foreign affair issues. In fact, the majority of history books reviewed here seemed to avoid the subject of colonialism. The ones that did mention colonialism did so only in passing and then only when talking about the financial problems being experienced in Western Europe at the time. Nevertheless, the examined history books covered a range of topics such as the Cold War, American 
foreign policy, the Truman administration, Great Britain's postwar history and Vietnam, which provided some useful information relating to the subject of colonialism.

The Cold War history books tended to touch on the issue of colonialism by how it affected individual crises rather than in a systemic way. An exception was Yale Professor John L. Gaddis' 2005 book, The Cold War: A New History, ${ }^{15}$ where the author spends a few pages discussing the demise of colonialism after the Second World War. Gaddis makes some interesting points, beginning with the previously propounded idea that the First and Second World War's were the root cause of the end of colonialism ${ }^{16}$ and that the consequences of these wars were realized twenty or thirty years later. ${ }^{17}$ Additionally, he claimed that Americans, including the State Department, opposed the concept of colonialism since this antiquated system reflected badly not only on the Europeans but on the United States as well. ${ }^{18}$ However, Gaddis' comments have to do with the people of the United States and the Truman administration in general rather than specifically with Truman, the individual. Another well-known Cold War historian and prominent Emeritus Professor from Cornell University, Walter LaFeber, discusses the topic of colonialism in the same general terms as Gaddis though he does not provide as convenient and encapsulated look at colonialism in the post-World War Two era. On the other hand, LaFeber's narrative goes into greater depth while focusing more on the economic aspects of colonialism. One of the most important aspects that LaFeber touched upon was that Americans disliked the closed markets that resulted from the protectionist trade methods intrinsic to the European colonial system. Another key point that LaFeber made was that the dislike of Americans' focused on the largest, best-known grouping of colonies that was the British Empire. ${ }^{19}$ However, LaFeber does not identify 
any particular person in the Truman administration as leading the fight against British colonialism. He does describe Truman and his advisors as attempting to deal with the instability of colonies, and former colonies, and contends that this instability had a ripple effect on a weakened Europe. ${ }^{20}$ Both books provide insight into the topic without providing a complete picture on the issue of colonialism.

There are numerous books discussing the field of diplomacy and United States foreign policy that touch upon the subject of colonialism. Two of the major works reviewed here that focus on the United States' perspective of diplomacy are LaFeber's The American Age: U.S. Foreign Policy at Home and Abroad 1750 to the Present ${ }^{21}$ and Ferrell's American Diplomacy: A History. ${ }^{22}$ Ferrell's book provides a brief account of FDR and Truman's lack of efforts in Indochina. He argues that they failed to stop the French government from attempting to re-exert control, particularly in the country of Vietnam during and after the war, and that this inaction sums up the issue of colonialism. Ferrell further says that France's attempt countered the trend of other postwar imperialist European nations who were starting to shed their colonies. ${ }^{23}$ LaFeber's foreign policy analysis provides a much broader picture of the United States' response to colonialism. As in LaFeber's previously reviewed Cold War book, economics again plays a big role in understanding the American standpoint and he covered Britain's Imperial Preference System of the 1930's which barred the United States from a number of profitable markets around the world. ${ }^{24}$ LaFeber does mention FDR's efforts to break up European imperialism including the Bretton Woods Accords that attempted to open British markets. ${ }^{25}$ He also comments about the friction during the war between FDR and both Winston Churchill and Charles de Gualle over the issue of colonialism. ${ }^{26}$ LaFeber's 
discussion of Truman and colonialism centered on the problems experienced in Indochina and, though he was quite clear about where FDR stood on the issue, he is vague on Truman's stance. In the case of the Netherlands and Indonesia LaFeber indicated that the United States forced the Dutch government to yield to Indonesian interests. Conversely, he implied that the Truman administration supported French efforts in Vietnam. ${ }^{27}$ Once again, the authors cited here provide some understanding of events which influenced decisions regarding the United States' foreign policy without providing either Truman's or his administration's overall position on the subject of colonialism.

\section{Charles Robertson's 1975 book, International Politics Since World War II; A Short}

History, ${ }^{28}$ looks beyond American centric foreign policies and into the international realm of diplomacy. Nevertheless, Robertson makes points similar to those touched upon by LaFeber and Ferrell though he also includes more about colonialism as it relates to the Truman administration. Robertson, Emeritus Professor of Government Smith College, links discussion of colonialism together with events during the Second World War and to activities of the European powers in the immediate postwar period. The basis of this connection was the decision by FDR's administration to give the British total control over the Southeast Asian theater of operations during the Second World War. ${ }^{29}$ This decision allowed European imperialists to more easily return to their old colonies as the Japanese withdrew. Robertson does cover efforts, not touched on by the earlier reviewed books, of both the Roosevelt and Truman administrations' to end colonialism by using the United States' influence in the United Nations to help formulate the trusteeship program. He also covers the familiar Cold War themes of declining European power, destabilization of the underdeveloped countries and the growth of a bi-polar world 
centered on the United States/USSR conflict. ${ }^{30}$ Robertson contends that Truman was aware that the European colonial system was waning and believed that the United States needed to help smooth the changeover from colony to nation in the underdeveloped regions of the world. He makes that point during his discussion about Truman's Point Four Program, a program intended to help underdeveloped countries transition from their former colonial status. ${ }^{31}$ While Robertson's book does consider the impact of colonialism on the period, more than the other volumes discussed, his primary focus remains upon the growing conflict between the United States and the USSR.

Other foreign policy books have examined the subject of colonialism and America's response in a much more roundabout manner. Nonetheless, they can still provide some insight into the issue and help to clarify fundamental points. The first book considered is an example where little mention is specifically made of colonialism yet it is still able to provide useful information. John Spanier's American Foreign Policy Since World War $\underline{I I}^{32}$ mentions economic factors in a manner similar to LaFeber's critical appraisal of the Cold War. The University of Florida History Professor Spanier talks about the importance of the Open Door trading model to American foreign policy and the traditional opposition of the European powers to that principle. ${ }^{33}$ He also touches on the impact of the severe weather that occurred during the winter of 1947 , which brought the economic problems of Britain to a head. ${ }^{34}$ Brutal winter conditions immobilized the country and produced a debilitating effect upon a British economy already suffering from the decline of the British Empire. This natural catastrophe had the additional effect of focusing the attention of the United States upon the plight of British and Western European empires. Another crisis related to the Truman administration discussed in the 
book, was Vietnam. Spanier noted that though Truman was unenthusiastic about the situation and troubled by the French actions in the region he nevertheless overcame his qualms and backed France's attempt to reassert influence over their former colonies. ${ }^{35}$ This American foreign policy book, with its limited references to colonialism, is typical for the majority of the books reviewed and illustrates how the reader is obliged to read between the lines to glean information on the subject.

An interesting exception is a book contemporary to the period. In 1956, the Brookings Institution published United States Foreign Policy $1945-1955^{36}$ by Professor of Political Science William Reitzel that provides further information about colonialism and the Truman administration. This book contains some Truman quotes from a 1946 State Department Bulletin that are anti-colonial. To summarize Truman's statement; he warns Great Britain and other nations with interests in the Far East that the United States supports the sovereign rights of native peoples around the world, further that no changes should occur without the express agreement of the local people and finally, that those same people should be able to ultimately choose their own government. ${ }^{37}$ Reitzel also makes other interesting points about the issue of colonialism and its affect on foreign affairs of the period. He talks about the Soviet Union's support for the decolonization movement in the underdeveloped parts of the world and the motivation behind their stance. He argues that the Soviet motives are to weaken the Western Block by diminishing European empires and to further their own aims by appearing sympathetic and encouraging to the developing countries of the world. ${ }^{38}$ Reitzel examines the United States' policy on the issue of colonialism during the immediate postwar period. The United States policy adhered to the idea that self-determination was inevitable and that 
everyone would gain from a methodical and orderly process. For this reason, the Truman administration believed that the United Nations should manage the transition process from colony to independent nation. ${ }^{39}$ The perceived threats to this approach were the Communists who would attempt to disrupt the changeover and foment chaos and anarchy for their own benefit. This viewpoint would endure in Cold War policy books during the ensuing decades until the end of the Cold War period. ${ }^{40}$

The next three books examined recount events and crises of the Truman administration with more insight into policy decisions relating, directly and indirectly, to the issue of colonialism. First considered is Washington correspondent and newspaper journalist Robert Donovan's work, Conflict and Crisis: The Presidency of Harry S. Truman. ${ }^{41}$ The book's discussion of colonialism centers on the British and French Empires. These empires were already declining when Truman assumed the role of President and the United States was beginning to fill the inevitable vacuum they were leaving behind. ${ }^{42}$ In the beginning of his administration, Truman assumed the policies left to him by FDR without apparent deviation. In an interesting aside, Donovan implies that FDR, not Truman, began the policy of support for the French return to Indochina. LaFeber originated the idea that FDR's anti-colonial stand weakened in the case of Vietnam and other historians then set out to explore his work. ${ }^{43}$ Donovan maintains that Truman was so overwhelmed with urgent concerns when he became President that, almost by default, he assumed a policy of benign neglect toward colonialism when he took over in the White House. ${ }^{44}$ In Britain's case, the transition from British Empire to Commonwealth seemed to be progressing well under Prime Minster Clement Attlee and his Labour Party, as illustrated by the end of colonial rule in India. Truman approved of 
this evolution and his appreciative attitude established a good working relationship between the two countries through the six years the Labour Party was in power. ${ }^{45}$ Nevertheless, Donovan explained that Truman's benign neglect on the issue of colonialism undermined his Asian foreign policy and brought about the crises in China and Korea later in his administration.

Walter Isaacson and Evan Thomas, at the time junior editors at Time and Newsweek magazines respectively, collaborated on The Wise Men: Six Friends and the World They Made. ${ }^{46}$ Published about ten years after Donovan's book, their work paints a similar picture of the Truman administration while reflecting different motivations for their actions. For example, the authors point out that Truman was inclined to follow FDR's lead when it came to foreign affairs and had a long track record of backing Roosevelt's policy decisions while in Congress and again as Vice-President. ${ }^{47}$ They also point to key differences between the Presidents' foreign policy management styles, which aid in understanding Truman's policies on colonialism. FDR was directive about his foreign policy objectives and the means he wanted to use to reach them while Truman was more of a team player who sought concurrence when dealing with diplomacy issues. ${ }^{48}$ The contention that Truman was more comfortable functioning as part of a team does play into the overall theme of the book that is about a group of senior diplomats and advisors to Presidents. Additionally, the idea that Truman based decisions upon consensus building does help to clarify his record on colonialism, since the authors make the argument that Truman's advisors were Anglophiles. This pro-British image does introduce the suggestion that Truman was less anti-imperialist than his predecessor was in office. Another important point made in the book was that with Churchill out of power 
the government was actively decolonizing the British Empire. ${ }^{49}$ In fact, the rapidity of British withdrawals caused concern within the Truman administration and forced the United States to compete with the USSR over filling the power vacuums created by the declining British Empire. ${ }^{50}$ The ensuing struggle with Russia caused the United States to drop the dissolution of the British Empire as America's foreign policy centerpiece and establish new objectives. With regard to the issue of France and Vietnam the authors do not subscribe to LaFeber's belief that FDR changed the United States' policy direction rather, they contend the Truman administration's Cold War objectives caused the divergence in the Vietnam policy from the earlier administration's position. ${ }^{51}$

The final book of this trio on Truman and his advisors was A Preponderance of Power $^{52}$ by Professor of History from the University of Virginia, Melvyn Leffler. Of these three histories, Leffler's book provides the most examples of the Truman administration's efforts to intervene in the issue of colonialism in the postwar period. He talks about the trend in United States foreign affairs to slow the process and reduce the upheaval caused by nationalist movements in undeveloped nations around the world. ${ }^{53}$ While other books touch upon the perceived phobia about Communist-sponsored underdeveloped countries' nationalism within the State Department Leffler also balances this phobia with other influences on Truman's foreign policy. Foremost was Truman the man. Truman's knowledge in relation to the field of foreign affairs was imperfect ${ }^{54}$ and resulted in some major blunders regarding the issue of colonialism. Two significant miscalculations occurred early in his administration when he underestimated the overall instability and weakness of Great Britain and Europe and then did not realize that the nationalist movements in the underdeveloped regions of the world were exploding out of 
control. ${ }^{55}$ Both of these missteps showed a lack of knowledge and experience and resulted in unintended consequences. Another example concerned the issue of overseas bases and the proposed United Nations (UN) trusteeship for islands in the Pacific. The retention of these holdings by the United States for military purposes served to undercut the trusteeship concept and undermined the whole process of decolonization. Both of these examples demonstrate the challenge of recognizing colonial-related issues, not identified as such, and serve to illustrate once again why a researcher needs to assess carefully all available information to understand Truman's position on colonialism. Leffler does mention that in Truman's first term the administration did attempt to support a policy of decolonization, to some extent, by calling on the major imperial European governments to reach some type of an accommodation with the various nationalist movements. ${ }^{56}$ The Truman administration also used their policy regarding granting autonomy to the Philippines as an example of how to approach decolonization. ${ }^{57}$ All the same, Leffler called these attempts by the United States State Department to influence European decolonization ineffective and halfhearted at best. ${ }^{58}$ In addition, he also agreed with LaFeber that FDR, despite his previously anti-colonial stance, was supportive of efforts to return French colonial rule to Indochina before the end of the war. ${ }^{59}$ Leffler concurs with the idea, which remains constant throughout all accounts of Truman's foreign policy, that the Cold War overrode all other concerns in the area of foreign affairs. ${ }^{60} \mathrm{He}$ also observed that obtaining millions of dollars through the Marshall Plan enabled the European empires to shore up their colonies. ${ }^{61}$ Therefore, Leffler argues that Truman's foreign policy decisions, such as implementing the Marshall Plan, were procolonial in nature. 
These three books about the Truman administration do provide insights into the United States government's response to colonialism in the postwar period and their accounts are more detailed than the other groups of literature reviewed. They portray Truman as wanting to follow the plans of FDR. They raise questions about the policies founded by the prior administration. Then, they consider the impact these previous decisions had upon Truman's perspective on the subject. Unlike the dearth of information regarding Truman vis-à-vis colonialism there have been several accounts published about Franklin Roosevelt's Presidency that offer arguments about whether or not FDR was against colonialism in both word and deed.

The generally accepted idea among the reviewed authors is that FDR was against the idea of empires ruling over a closed economic system of colonies. ${ }^{62}$ These books and articles support the view that FDR's rhetoric was anti-colonial. The first book in a series of Roosevelt histories reviewed is the 1989 edition of Major Problems in American Foreign Policy Volume II: Since $1914^{63}$ which includes an essay taken from a book titled The United States at War, 1941-1945 by Bowling Green University Professor Gary Hess. ${ }^{64}$ Hess reiterates Roosevelt's known postwar objectives, including one that called for "the gradual demise of colonial empires leading eventually to independent states in Asia and Africa." ${ }^{, 65}$ In the same essay, Hess considers the practical aspects of FDR's policy as well as the 1945 Yalta accords that establish the idea of the United Nation's Trusteeship System. The trusteeship agreement wording is sufficiently general that former and current colonies might, or might not, be included. Then in addition, Roosevelt, and other participants of the Yalta Conference, decided to put off the selection of actual territories to be in the trusteeship program until a later date. ${ }^{66}$ The vague 
wording of the agreement and delay in identifying specific territories for inclusion was a deliberate choice made by Roosevelt in order to protect the allies' fragile coalition. ${ }^{67}$ Still, Hess argues that FDR was an unwavering champion of decolonization and that he focused his efforts on French colonies in Indochina to set an example for other colonial powers, particularly the British Empire. ${ }^{68}$ A 2003 book titled Franklin D. Roosevelt and the Formation of the Modern World, ${ }^{69}$ reinforced the view that FDR believed colonialism was not only a bad social and economic concept but that its continued existence would be the biggest threat to the expansion of democracy in the postwar world. ${ }^{70}$ The contributor of this chapter, and co-editor of the book Howard Thomas, Professor of History from Virginia Polytechnic Institute and State University, believes that the British were the focus of FDR's anti-colonial stance, which coincides with what Hess suggested in his essay. ${ }^{71}$ Howard also agrees that Roosevelt did not waver in his opposition to colonialism. In fact, Howard thought that FDR's position was undermined after his death when, at the first meeting of the United Nation's Trusteeship Council, the United States delegation yielded to European pressure and changed the wording of the council's purpose from helping territories achieve independence to the more benign term of attaining self-government. His analysis places the blame for the weakening of the trusteeship program, and thus its ability to help end European imperial rule, squarely upon the Truman administration. Other authors also share this view. In a 1972 article, Hess claims that Truman killed the trusteeship concept by his support for the French intentions in Indochina. Moreover, Hess blames FDR for not doing enough to protect the trusteeship idea and guarantee his anti-colonialism legacy. ${ }^{72}$

Reverend Wilson Miscamble, Professor of History at Notre Dame University, 
considers the question of FDR's colonial foreign policy in his 2007 book, From Roosevelt to Truman: Potsdam, Hiroshima, and the Cold War. ${ }^{73}$ He makes the point that Roosevelt was opposed to colonialism and viewed it as a bigger threat than communism. ${ }^{74}$ He also incorporates the conventional view that FDR kept his own council when it came to issues of State. ${ }^{75}$ Miscamble alleges that the explanation given to the analysis of FDR's foreign policy hinges upon the historian's viewpoint, in that Roosevelt was either a realist or a naïve operator in the realm of foreign affairs. According to the author, these conflicting interpretations of FDR's policies rest upon judgments by analysts about whether or not a decision by FDR had the desired effect. In some respects, Miscamble does deviate from other interpretations of FDR's efforts towards decolonization. He claims that FDR's objective to promote independence for former colonies always took a back seat to the necessity of protecting the wartime alliance and ensuring that the United States remained the dominant partner well into the postwar period. Miscamble contends that the truth of the situation was that Roosevelt's administration took no practical steps, beyond the President's persuasive rhetoric, to establish a true anti-colonial policy. ${ }^{76}$ Additionally, FDR did not share the particulars of his policies with anyone; hence, the means used to achieve his goals were open to interpretation upon his death. ${ }^{77}$ This understanding of FDR's legacy differs from the other books reviewed which take a stand, one way or the other, on FDR's anti-colonial efforts. For example, a 1982 book by John Gaddis explains FDR's brilliant use of the term linkage to describe the combine use of the powers of State to breakup the British Empire during the war. ${ }^{78}$ Conversely, a 1975 article by LaFeber places the blame upon FDR for reversing his position on the trusteeship program during the later part of the war 
and well before Truman took over in the White House. ${ }^{79}$ Lastly, Miscamble embraces another theme consistent with other Roosevelt histories. While FDR disliked all the colonial powers in Europe, he focused his efforts on Churchill and the British Empire. ${ }^{80}$

The British centric histories of decolonization in the postwar period point out that they did more than any other European power to bring about the end of colonialism. ${ }^{81}$ Only two of the researched books about the British Empire discussed the Roosevelt and Truman administrations to any degree. The first book, British Decolonization, 19461997: When, Why and How did the British Empire Fall? ${ }^{82}$ by New Zealand's University of Canterbury History Professor David McIntyre, cites the pressure of the United States on the British government during the Second World War as a major factor in hastening the end of the British Empire. He adds that the inception of the Cold War in the late 1940s reduced the impetus for the United States to end colonial rule. ${ }^{83}$ This position is at odds with British reporter Brian Lapping's book End of Empire ${ }^{84}$ where the author examined United States policies on a case-by-case basis to assess the overall effect it had upon Britain's decolonization efforts after the war. Specifically, Lapping cites Palestine and Egypt as case studies of the United States' efforts to end colonialism in the postwar period. ${ }^{85}$ In the case of Egypt, Lapping also goes on to cite other motives for the United States efforts to end Britain's colonial power in the oil rich region. He also argues that in the case of Palestine, Truman was looking more at Jewish voters in the United States than events in the Middle East when he recognized the State of Israel. ${ }^{86}$ These two Britishcentric books agree about the Roosevelt administration's decolonization policy but reveal a mixed interpretation of United States policies under Truman. 
An additional review of the joint United States / United Kingdom (UK) postwar foreign policy history provides a more inclusive picture of both the FDR and Truman administration's efforts toward British decolonization while simultaneously reinforcing points made in other books examined in this section. The book, The United States, Great Britain, and the Cold War: $1944-1947^{87}$ by Texas A\&M University History Professor Terry Anderson, makes Roosevelt's hatred of the British Empire sound even more vicious than other accounts. ${ }^{88}$ Contrary to other versions, Anderson states that the early Truman administration renewed demands on the British to end imperialism. Moreover, the author contends that the new President personally disliked the British colonial system, and was suspicious of Churchill's efforts to enlarge the British Empire after the war. ${ }^{89}$ Anderson also makes the point that Truman made an effort at the beginning of his time in office to continue FDR's foreign policies. ${ }^{90}$ Additionally, he claims that the desire to expand United States businesses into new markets, such as those found in the economically sheltered colonies of the British Empire, reinforced Truman's decolonization position. ${ }^{91}$ Anderson notes that Truman's position later evolves because of the Cold War and refocuses on opposing communism rather than colonialism. ${ }^{92} \mathrm{He}$ also argues that another factor to consider when discussing the British process of decolonization was the assumption of power by the Labour Party whose stated goal was to transform the British Empire into a Commonwealth. ${ }^{93}$ Anderson's depiction of Truman as a new President shows an individual who shared Roosevelt's dislike and distrust for the British's colonial regime. In the same vein, Ohio State Professor of History Peter Hahn observed in his book The United States, Great Britain, and Egypt. 1945-1956: Strategy and Diplomacy in the Early Cold War ${ }^{94}$ that the Cold War did divert 
the United States from decolonization efforts and focused attention upon the Soviets. Nevertheless, Truman's administration still sought to diminish British domination over their colonies, especially in the Middle East. ${ }^{95}$ However, the British Empire was not the only European power to come under the United States scrutiny. An examination of the literature concerning the French colonial system provides another viewpoint about the history of Truman and his administration.

The final collection of literature reviewed for information about Truman's position on the issue of colonialism concerns the Vietnam histories. As with the other groups reviewed here, the histories on Vietnam reinforce the idea that Roosevelt was opposed to colonialism and against French efforts to return to Indochina. However, an entry found in the 2003 Major Problems in the History of the Vietnam War by Purdue University History Professor Patrick J. Hearden ${ }^{96}$ does indicate that shortly before his death FDR was softening his position and not pushing for trusteeship of the former Indochina colonies. ${ }^{97}$ The fact that Roosevelt was beginning to back off in this area is reinforced by the most notorious, if not the most definitive, history of the Vietnam conflict commonly called the Pentagon Papers, which indicate a moderation of FDR's position by $1945 .^{98}$ If Roosevelt had indeed shifted his position this action could indicate whether Truman's subsequent policy decisions were in fact a continuation of the former President's policies or a sign of Truman's true feelings. At the very least, questions about the softening of FDR's anti-colonial stance and uncertainty about policies of one administration transferring intact to the next indicate a more complex interpretation of events than indicated elsewhere. Regardless of the underlying reasons, most histories agree that France's attempt to restore their colonial control over Indochina in the postwar period 
drew the United States into the Vietnam War. In fact, many historians cite Truman's 1950 decision to provide aid to France for operations in Vietnam as the beginning of the United States' involvement. ${ }^{99}$ Other books, such as University of Massachusetts Professor of History Loren Baritz's Backfire, ${ }^{100}$ consider aspects of the Truman administration's Cold War mentality, such as the Truman Doctrine and National Security Council Study (NSC-68), as even more evidence to link Truman to America's involvement in Vietnam. ${ }^{101}$ That aside, the fact that Truman provided financial support to French operations in Indochina provides the most substantial evidence so far that Truman might endorse colonialism.

At length, one can see that by reviewing the period's literature, drawing upon associated subjects and considering persons of interest a researcher can identify some themes that influenced Truman and his administration's position on the issue of colonialism. For example, extensive analysis of Roosevelt's position concerning colonialism is available and various conclusions are discernible. First, no doubt exists that FDR opposed colonialism in any form though there are some questions about the state in which FDR left the decolonization policy upon his death. Depending upon the author one can find arguments that Roosevelt had: 1) a robust decolonization program;2) an ineffectual program based solely on rhetoric; or 3) a policy that was in actuality diverging from its originally anti-colonial position. In the same vein, again depending upon the author, one can find a depiction of Truman as either steadfastly supporting FDR's legacy or changing foreign policies to a Cold War-centric view of the world with little room for anti-colonialist sentiment.

The examined literature includes both academic works like the volumes by LaFeber, 
Gaddis and Hahn as well as books aimed at a broader general audience such as McCullough and Lapping's. The academic works included many entries by historians but also contained publications by political science scholars that helped to augment the inquiry by providing access to diverse methodologies and points of view. Nevertheless, across this varied spectrum no significant differences were discernable between authors from the various specialties when they discussed similar material. Real differentiation was noted when the analysis was divided into subject areas which encompassed Truman, his administration and the state of colonialism in the postwar period. For example, Cold War history books place little importance upon the subject of European colonialism and dedicate little analysis to the issue and even less to Truman's role. The primary exception is that most of the books and articles do discuss Truman's role in helping French efforts to reestablish colonial rule over Indochina. Other than that, when the subject of American anti-colonialism comes up in Cold War literature the issue of colonial markets closed to external competition is also raised. LaFeber provides the best description of opening colonial markets when he writes about the United States' perpetual quest for new markets under the guise of the "Open Door" policy. ${ }^{102}$

Another theme garnered from the literature was that the United Nations' trusteeship program was at the center of the United States' decolonization efforts. Both the Roosevelt and Truman administrations wanted the United Nations to take on the role of supervising the demise of the European empires and developing the emerging nations in the postwar period. Complementing this approach was the belief by Truman, among others, that decolonization should be a deliberate and orderly process. However, the ultimate impact the trusteeship program had and the support it received from the United 
States is open to debate. Moreover, while the United States expected the United Nations to establish systemic means to help develop new nations there was still concern that the USSR would seize control of nationalist movements in the underdeveloped regions of the world. Thus, the fear of Communist expansion links to the issue of decolonization as expressed in the Truman administration's Cold War rhetoric.

The effect Truman's other foreign policy programs, the Marshal Plan and the Point Four Program, had upon the issue of European colonial rule is uncertain. Some accounts point to the Marshal Plan's funding of European powers as bolstering their efforts to shore up control in their colonies but these reports are vague about the true intent of the Truman administration. There does not seem to be a consensus about whether these programs intended to help the Europeans recover from the debilitations caused by the Second World War or instead were elements of a unified policy to shore up European control over their colonies.

The British-centric history books mentioned that the United States applied pressure on Britain during both the Roosevelt and Truman administrations, to expedite the decolonization process in Palestine, Egypt and India. As a point of fact, Great Britain was not the only European country pushed by the United States to facilitate decolonization. The literature indicates that the Americans also prodded the Dutch government to settle with its colonies in Indonesia. However, most European countries wanted to retain control of their colonial holdings. England was the exception with its accelerated transformation from the British Empire to a Commonwealth under the postwar Labour Party.

As asserted at the beginning of this historiography section, and confirmed by a review 
of a number of books and articles, no established schools of thought exist which address Truman's position on the European empires of the postwar period. However, of the books written that focus on the Cold War and the administration, Gaddis' Cold War book provides the most persuasive support for the idea that the Truman administration was against the concept of colonialism. Furthermore, LaFeber's in-depth analysis, reinforced by the other writings noted here, endorse the concept that Americans have an inherent dislike of the closed markets that grow from colonial systems. This analysis adds force to Gaddis' notion about the Truman administration's anti-colonial stance. Therefore, based upon the sources examined, a reasonable interpretation is that there was an anti-colonial attitude in the Truman administration. When discussing Truman's private convictions the biographies naturally provide the best insight into Truman's personal response to colonialism. McCullough's biography is the most readable and provides an engaging picture of the President from Missouri. Hamby's Truman is similar to McCullough's but he backs up his analysis with more in-depth research. They both depicted President Truman as an intelligent man who, while not brilliant, grew into the job. Additionally, they portray Truman as practicing consensus building and point up the fact that he was active in the arena of foreign affairs relating to colonialism. Ferrell's research is welldocumented but does not focus on foreign policy subjects relating to colonialism, such as international trade, and therefore is less useful concerning the topic of this paper. None of the biographies captures Truman's dislike for colonialism in unmistakable terms that provide firm conclusions. As for Roosevelt's legacy on European colonialism and Indochina, the detailed research and facts in the books by Robertson and Donovan best capture his deep dislike for colonialism while he was still compromising with the 
European powers over the colonies postwar future. However, none of the books satisfactorily addresses the conjecture over the meaning and impact of FDR's decisions to allow France's return to Indochina.

Even with the themes found in the material examined, no widespread consensus is apparent about the Truman administration's position on European colonial rule. As a result, further analysis is required to decipher the information and determine what Truman's personal and policy positions were concerning imperialism. The remainder of this paper will attempt to draw upon the material reviewed and the data collected to provide an answer to the question of whether Truman supported or opposed colonialism and whether his enacted foreign policies supported his personal position. 


\section{CHAPTER III}

\section{FRANKLIN D. ROOSEVELT / WORLD WAR TWO}

As discussed in the historiographic section of the paper, FDR appears to be anticolonial and anti-imperialist. Roosevelt's anti-colonial tendencies become more apparent when talking about FDR and the British Empire. This section will build upon the information already presented about Truman's predecessor and examine FDR's legacy on the subject. Also reviewed will be the state of the existing policies about European colonialism that Roosevelt's administration left for Truman and his team to deal with in the waning days of the war and beyond. The assessment of FDR's legacy will help to clarify the circumstances, both within the government and in the world at large, which framed Truman's understanding of the world beyond the United States borders and his administration's foreign policy concerning European colonization.

First, FDR's position on the evils of colonialism did not develop in a vacuum but rather was the prevailing view among the American population before the Second World War. However, during that conflict a wartime rapport developed between the United States and the United Kingdom. Winston Churchill, in his famous 1946 Iron Curtain Speech at Westminster College in Fulton Missouri, even gave a name to this close

association as the "Special Relationship". ${ }^{1}$ Churchill's speech, given in Truman's home state a year after Roosevelt's death, indicated that this rapport remained strong even as 
the Cold War was heating up. The unique nature of this bond was no doubt due in large part to the common history, language, and traditions shared by the two nations. The affinity alluded to by Churchill in his 1946 speech had contributed to the unprecedented associations undertaken by the two nations' leaders and militaries which combined their staffs in order to plan and conduct operations during the Second World War. ${ }^{2}$ Just a few of these joint organizations included, "the Combined Chiefs of Staff, Combined Food Board, Combined Production and Resources Board, Combined Raw Materials Board ... and later the Manhattan Project."3

In spite of the close relationship, some frictions existed between the two nations. For instance, historically Americans have disliked anything English, a mindset that goes back to the colonial period of North America. The American Civil War when the British entertained the idea of establishing formal diplomatic relations with the Confederacy reinforced this attitude. The English also profited from doing business with the rebels, which upset the Northern population. The most notorious example of this profiteering was when the British built three heavily armed commerce raiders, the Florida, Shenandoah and Alabama, for the Confederates. The Confederate navy then used these vessels to conduct wartime operations that included attacking Northern-whaling ships. ${ }^{4}$ The Union wartime press angrily described the Confederate-commanded raiders as "Built of English oak, in an English yard, armed with English guns, manned by an English crew ...." In the early Twentieth Century, there had been some popular anger over England's failure to pay off World War One debts, and in the 1920s and 1930s politicians were currying favor with the American Irish by running anti-British campaigns. ${ }^{6}$ FDR understood this historic animosity and tried to explain to Churchill how Americans could 
work with the British while still harboring ill feelings towards them. Roosevelt said, "I've been trying to tell him ... It's in the American tradition, this distrust, this dislike and even hatred of Britain-the Revolution, you know, and 1812; and India and the Boer War, and all that."

Despite this historic enmity, a major part of America's Anglophobia later focused upon various aspects of British colonial rule that many Americans considered archaic, and not befitting modern times. In reality, American anti-imperialism to a large degree caused the British central government to alter some colonial policies during the war, such as promising their prize colony of India independence. The British realized that, to some extent, future British colonial polices needed the backing of American financial capital. ${ }^{8}$ Popular American publications in Great Britain at the time, like Life magazine with its 1942 article titled, "An Open Letter from the Editors of LIFE to the People of England," further impressed the anti-colonial feelings of the American population upon the British people. The Life article enlightens the British people about the American viewpoint on the British Empire in general and the colony of India in particular: ${ }^{10}$

... one thing we are sure we are not [emphasis from original] fighting for is to hold the British Empire together. We don't like to put the matter so bluntly, but we don't want you to have any illusions. If your strategists are planning a war to hold the British Empire together they will sooner or later find themselves strategizing all alone .... In the light of what you are doing in India, how do you expect us to talk about 'principles' and look our soldiers in the eye? ${ }^{11}$

The editorial pages of other well-known United States publications such as the New York Daily News and the Chicago Tribune also mirrored this attitude. ${ }^{12}$ Near the end of the war Anglophobia, and its associated rhetoric, had grown to such an extent that it was affecting public opinion of the United States' closest wartime ally. ${ }^{13}$ A national poll conducted during 1943 showed this anti-imperialist attitude toward the British by 
disclosing that eighty percent of Americans supported rapid independence for the British colony of India while only twenty percent supported continued British rule. ${ }^{14}$ Around this time, John Hickerson, the State Department's head of European Affairs, also sent a letter to Dean Acheson which summarized the popular opinion, "As you know, there is tendency in this country to blame the British in some way for everything that happens that we don't like."15 Furthermore, by the end of the war most of the higher-ranking representatives in American government felt as did Sumner Welles, a senior State Department official, "If the war is in fact a war for the liberation of peoples, it must assure the sovereign equality of peoples throughout the world .... The age of imperialism is ended." ${ }^{\prime 6}$ A 1975 oral interview with Elbert G. Mathews, a retired State Department official who oversaw British affairs during the war, verified this belief about the empires:

I have the distinct impression that during the latter part of the war, when colonial questions arose, most people in the Department took a Rooseveltian view: the less colonialism, the better. Yes, I think this is true. It's certainly true of those I was working with, my own attitudes. In other words, with respect to India, all of us thought, you know, independence, the sooner the better; they're going to have lots of problems, but the day of the British Raj is over. ${ }^{17}$

Most Americans were not openly hostile to the British, instead viewing them "... as a misguided friend unfortunately wedded to a dangerous and outmoded behavior." ${ }^{18}$ FDR operated in this domestic environment throughout the Second World War and the Truman administration assumed the mantle of leadership against this backdrop.

Another aspect of colonialism, which drew public and governmental interest in the United States, was the issue of trade. In the 1930s, the British government angered many in the United States when their answer to the Great Depression was the erection of even greater trade barriers. While colonial rulers have traditionally restricted some access to 
colonial economies, the British, to the particular detriment of American businesses, intensified the restrictions on outside trade. The British established the Imperial Preference System that gave trade benefits to all members of the Commonwealth. This approach included more than just the traditional underdeveloped colonies in Asia, the Middle East and Africa. The new protectionist rules also included the British Empire's developed and sovereign countries such as South Africa, Canada, Australia and the United Kingdom. ${ }^{19}$ John M. Leddy, a State Department official involved with trade issues at the time, described the general impression the United States gathered about the purpose of the British Imperial Preference System:

In other words, it was a way for British industry to get a lock on particular foreign markets which happened to be politically related to it--the Empire and the Commonwealth. This affected the underdeveloped world as well, and not just the United States. All non-British areas were discriminated against in the British market by the preference system. Because the preference is nothing more or less than a tariff discrimination. Therefore, we felt that if tariff barriers and trade barriers were to come down all over the world then preferences ought to be eliminated, as a part of that process. The ideal being that you should, generally speaking, between separate customs territories at any rate, or quasi-independent areas, apply the principles of the unconditional most-favored-nation clause, or nondiscrimination .... But the great bulk of opinion in the State Department and in the Government, and I must say I think, indeed, in the Congress as well was that the British preferential system was an imperial system. It was a colonialist system. It was one that had bred a great deal of friction between us and the British, and that it ought to be junked. So that was our position. ${ }^{20}$

Furthermore, others believed that the system created greater economic hardships for countries that had more limited natural resources, such as Germany and Japan, by denying them access to needed crops and raw material. ${ }^{21}$ The economic obstructionist aspect of the Imperial Preference System is important because it influenced the Great Depression, World War Two and the early postwar period. Another issue that affected the Roosevelt and Truman administrations was the developing nationalist movements 
around the world. The movements had been building for some time but the depression of the 1930 s seemed to speed up the process and riots were breaking out in various colonies around the world, such as the British West Indies. ${ }^{22}$

During wartime, FDR had to balance maintaining the alliance while working toward his goals concerning the postwar world. John Sebrega notes that when Roosevelt was thinking, "about the postwar world, he did so frequently in terms of the problems of the prewar world. In other words, he wanted to remove permanently the conditions that had blighted international affairs during his lifetime. ${ }^{, 23}$ Roosevelt was a long time disciple of Wilsonian internationalism dating back to his time in Woodrow Wilson's administration as Assistant Secretary of the Navy. ${ }^{24}$ FDR even championed and defended Wilson's foreign policy beliefs during the heyday of isolationism in the 1930s. ${ }^{25} \mathrm{He}$ also adhered to the Open Door policy saying he wanted to end "all those artificial restrictions and controls ... which had created such tragic havoc to world economy during the past generation." ${ }^{26}$ Given this background, it is understandable that Roosevelt's aim was to end the chance of future wars through international efforts like those at the Dumbarton Oaks conference and to establish the economic security freedom called for in the Bretton Woods Agreement, which would protect against another Great Depression. ${ }^{27}$ The postwar portion of FDR's overall agenda also called for the United States to take on a greater role in world affairs, establish some kind of amenable relationship with Russia, and develop China into a friendly regional power. ${ }^{28}$ A portion of this agenda, relating back to his belief in fundamental liberties for all people articulated in his Four Freedom's Speech, ${ }^{29}$ aimed at ending conditions such as he saw during a 1942 trip to the British colony of Gambia, which he described as, "The most horrible thing I have ever seen in 
my life."30 More to the point, colonial rule, with its restrictive trade practices and oppression, was likely to sow the seeds for more volatility and future world wars. ${ }^{31}$ The lofty words of the 1941 Atlantic Charter called for territorial adjustments per the wishes of the native peoples, affirmed that people have the right to self-determination, and stated that there should be an end to trade barriers. ${ }^{32}$ There are also the words that FDR used during a 1941 speech to a gathering of the press, "There has never been, there isn't now, and there never will be, any race of people on earth fit to serve as masters over their fellow men .... We believe that any nationality, no matter how small, has the inherent right to its own nationhood." 33 Pursuit of international social reform provoked the cynical British allies who believed that personal hatred and jealousy tainted Roosevelt's attacks on the British Empire. For instance, the British Foreign Secretary once questioned FDR's sincerity when Roosevelt called for the independence of Hong Kong, saying that the President had never offered freedom to any of America's regions like Hawaii. ${ }^{34}$ Still, FDR's primary goal was to maintain the coalition and sustain a reasonable level of trust with the other alliance leaders. The balance between preserving the alliance and urging the end of European empires would prove to be a harder challenge as the war went on. ${ }^{35}$

The biggest obstacle to stabilizing the postwar order was Great Britain, with its huge colonial empire, and its staunch defender Churchill. Churchill, like others in Europe, understood only that their empires had enabled them to defend against the Germans and their allies in both World Wars. ${ }^{36}$ Churchill's fear was that without the resources of the British Empire, if another war came the nation would be lost before the Americans could come to their aid. Churchill understood that various colonies would need increased 
freedoms but believed that they should remain under the benevolent umbrella of the European powers lead by Her Majesty's Great Britain. ${ }^{37}$ Churchill's mental picture for the future envisioned the traditional balance of power in Europe as radiating out to the rest of the postwar world. Thus counterbalancing what he expected to be the greatest threat to world peace, Russia.

Some in Whitehall listened to the American anti-colonialist rhetoric during the war while others, like Churchill, did not wish to heed the message. ${ }^{38}$ These words capture Churchill's absolute opposition to decolonization, "While there is life in my body no transfer of British sovereignty will be permissible."39 While not winning every battle, the pro-empire Churchill was quite successful in fending off many of FDR's attacks on the solidarity of the British Empire. ${ }^{40}$ When Roosevelt pressed in 1942 for Indian independence, Churchill feared instability in the region and fought back. He threatened to resign saying, "I have not become the King's First Minister to preside over the liquidation of the British Empire."

FDR's stratagem to deal with the threat to world stability caused by European colonial rule was to implement a variety of foreign policies that would force change. One of the earliest tactics was establishing the Lend-Lease Act that called for the British to begin eliminating the Imperial Preference System and open their markets to United States trade through shared use of navel and air bases in Newfoundland, Bermuda and the British West Indies. Private messages, published later, showed that tying the colonial trade issue into the Lend-Lease negotiations was a topic of singular friction between the two leaders. In that same correspondence, Churchill expressed his fear that the British nation would become a second tier actor on the world stage. ${ }^{42}$ Leo Amery, at the time the British 
Secretary of State for India, summed up the quandary the British faced by relaxing the Imperial Preference System because of the American Lend-Lease deal:

We. in our anxiety to secure Lease-Lend and bring America in (to the war), have never had the courage to say straight out that Imperial Preference is not merely a matter of economic policy but a natural political right of the British Commonwealth .... Imperial Preference means so much to our own export trade and to many parts of the Empire and we may well find ourselves, all of us, after the war, even more dependent upon inter-Empire trade than at present. ${ }^{43}$

In the end, the British had little choice but to give in and give the Americans what they wanted in exchange for needed support.

Another example of Roosevelt's early efforts to force change upon the British Empire came in the Caribbean where the United States State Department promoted public unrest by opening up a direct dialogue with the locals that served to weaken British control in the area. The transfer of American naval destroyers to several British colonial Caribbean bases allowed more American influence and trade into those regions. The establishment of a United States-instigated joint regional commission, with a decidedly American slant, to collaborate on air security as well as other economic and social issues, followed the transfer of ships in the Caribbean. The United States later duplicated the regional commissions in other British-controlled areas. ${ }^{44}$ These anti-colonial actions in the Caribbean occurred prior to any other United States/United Kingdom tensions over colonies and probably occurred because of the proximity of the region to America.

A further case in point of Roosevelt's persistence in pursuing an anti-colonial policy appears in 1943 when he had the United States representative in India publicly advocate the idea of granting the colony Dominion-status similar to Canada. ${ }^{45}$ FDR had wanted to address this issue ever since 1941 when he had confronted Churchill about it privately. That 1941 argument had so angered Churchill that the Prime Minister later said that 
Roosevelt "never raised it verbally again." ${ }^{\text {"46 }}$ Colonialism in general, and India in particular, was the one subject that neither FDR nor Churchill could talk about in civil terms in what was generally a congenial personal relationship. ${ }^{47}$ It is somewhat ironic that while Churchill opposed Germany's domination over the European continent, nevertheless he believed that protecting the British Empire was his personal mission, even if it interfered with his affinity for FDR. ${ }^{48}$

The most critical feature of FDR's efforts to end colonial rule was the concept of trusteeship. Roosevelt saw the trusteeship program as a way to let allies manage the orderly transfer of power to colonies without the chaos that could ensue in the undeveloped parts of a postwar world. ${ }^{49}$ Initially, Churchill and the British were against the idea, suspecting that it was a ploy designed to remove British influence from various regions so that Americans could step in with their own informal colonial rule. ${ }^{50}$ Being the largest of the European empires the British viewed themselves as the spokesperson for the entire institution and they believed that the concept of trusteeship was another manifestation of American jealousy that they needed to block. ${ }^{51}$

England's empire was not FDR's only concern since there were other European empires that drew his attention. For example, France, with its colonies in Indochina, forced Roosevelt into dealing with the universally disliked General Charles de Gaulle and caused the President to be mindful of France's colonial problems. ${ }^{52}$ France was a difficult country for FDR to work with since, as Secretary of War Henry Stimson said, Roosevelt "hated de Gaulle so fiercely that he was almost incoherent on the subject." 53 Additionally, Roosevelt thought that France did not deserve treatment as a world power given their abysmal failure against the Germans. ${ }^{54}$ FDR also had a deep-seated feeling 
that France, under de Gaulle's inept rule, would fall into anarchy and civil war in the postwar period. ${ }^{55}$ Nevertheless, pressuring the British to release its hold on colonies during the course of the war had proven difficult, so concentrating on the French seemed to be an easier tactic since those colonies were already under Axis control. ${ }^{56}$ Hence, though the British possessed the most colonies globally, FDR later focused on the French as practicing the worst form of colonial exploitation and leaving native populations in terrible circumstances. ${ }^{57}$ Roosevelt's ability to compartmentalize troubles does create some confusion about his true position though, a prime example of which was his handling of the Indochina situation near the end of the war. When faced in January 1945 with the problem of how to handle the rapid Japanese departure from Indochina, instead of trying to set up a local government, amid other more pressing troubles, FDR told the Secretary of State, "I still do not want to get mixed up in any Indochina decision. It is a matter for post-war." 58

Towards the end of the war, the British used joint commissions, modeled after the previously discussed Caribbean commission, to their advantage. By 1945, the British worked colonial development projects through the commissions that gave the impression that the United States was part of those ventures. Another piece of good news for the British was that by then the American anti-colonialist rhetoric seemed to have peaked. ${ }^{59}$ Moreover, pressures within FDR's administration were growing to reduce the emphasis on the trusteeship program and anti-colonial viewpoint. Pentagon officials wanted to retain Pacific territories gained from the Japanese and Roosevelt's White House advisors, in conjunction with important members of Congress, were urging a more tolerant interpretation of the trusteeship program. ${ }^{60}$ More significant from the British 
government's point of view, were the positive diplomatic discussions between British and American officials at Dumbarton Oaks and later at the Yalta Conference where Roosevelt himself backed off on implementation of the trusteeship program. ${ }^{61}$ The scope of the plan was narrowed so that, while it could be applied to other territories, the program would only officially pertain to League of Nation mandates that were in enemy occupied lands ${ }^{62}$ and "any other territory that may voluntarily (emphasis from original) be placed under trusteeship." ${ }^{63}$ By agreeing to this wording, the entire concept changed, with the British becoming exempt from the trusteeship's effects, at least in the short term. With this modification to the trusteeship idea, Roosevelt also seemed to relax his position concerning Indochina in that he would not interfere with the return of the French and other European powers to the area ${ }^{64}$ FDR reinforced this position by agreeing at the Quebec Conference to let the British retain control of the South-East Asia Theater of Operations thereby enabling the British to secure former colonial Burma and Malaya, the Dutch to return to the East Indies and the French to hope for renewed influence over their old colonies in Indochina. ${ }^{65}$ There are different interpretations for this lessening of American anti-colonialist foreign policy. One view is that FDR was reconsidering his position on European colonial rule and becoming less anti-imperialist in thought.

The weakening of the trusteeship program at that point in time raises the question of whether, had he lived longer, Roosevelt might have reversed his policies on colonialism. ${ }^{66}$ The most likely answer to that query is that FDR, being a brilliant politician, was just adapting to the current situation as he had done numerous times in the past, and in all likelihood was not about to change his core beliefs. This explanation argues that the retreat on the trusteeship program was a tactical ploy. The fact that 
Roosevelt did not make any obvious public changes to his attitude about colonialism during this period reinforces this point of view. Almost certainly, Roosevelt decided to pull back on this particular issue in the short term, to maintain good work relations with the other nations and with the intention of addressing it again in the future when circumstances permitted. FDR saw decolonization as a long-term process as shown when he said that independence for the French colonies in Indochina could take "perhaps twenty to thirty years. ${ }^{167}$ One must also remember that Roosevelt had to balance his anticolonial objectives with his other essential goals: winning the war, maintaining the alliance and supporting his military leaders. ${ }^{68}$ On a strategic level, following the Yalta Conference, FDR told his cabinet at a meeting on 9 March 1945 that he was determined to pursue his original definition of trusteeship. Furthermore, about this same time he told Charles Taussig, a close friend, that full independence should be the ultimate aspiration for all colonial peoples. ${ }^{69}$ Therefore, it is apparent that Roosevelt's easing of the emphasis on which territories to include in the trusteeship program was not a FDRsanctioned mandate for President Truman to change the United States' established anticolonial foreign policy. Rather, it shows that the subject of European colonialism was a complicated, intricate issue that took place in the even more complex and multifaceted arena of foreign affairs.

Truman's Presidential decisions on colonialism need consideration on their merits and not through the distorting lens of supposition about whether or not they should have maintained the previous administration's policies since it appears that those policies were in flux..$^{70}$ Even so, this focus on Truman does not mean that one should ignore FDR's extensive record on the subject. After all, Roosevelt's well-known attitude towards 
colonialism and his foreign policy actions established the baseline for the new regime. FDR's administration championed the cause of colonial freedom and national selfdetermination all through the Second World War even if the President was occasionally required to soften his efforts from time to time. ${ }^{71}$ Considering Roosevelt's anticolonialist heritage from the perspective of the situation that Truman found himself in on 12 April 1945 does FDR a disservice. To appreciate Roosevelt's anti-imperialist legacy one should consider ". . . the broad outlines of his foreign policy . ..."72 such as his Four Freedoms speech and the Atlantic Charter. ${ }^{73}$

Although the nation and world were changing, some conjectures are possible concerning the domestic situation that Truman faced in 1945 based upon information from the prior discussion. The relations between the two English-speaking nations were warm though there were some public frustrations over Britain's colonial practices. While people in the United States felt that the entire European colonial system was an outdated and obsolete institution, the British bore the brunt of United States hostility toward the practice. The sheer size of the British Empire, the belief that Britain was still a major player in world affairs, the United States' own colonial history, and the draconian trade practices still in place from the 1930s, influenced Americans' animosity. As for the government, FDR's public rhetoric leaves little doubt about the administration's official position. Though Roosevelt maintained close ties with wartime England, he was unabashedly anti-imperialist. While decolonization was an issue near and dear to Roosevelt's heart nevertheless pursuit of those objectives, as demonstrated by the case of colonial trusteeships, remained secondary to the more immediate goals of winning the war and maintaining the alliance. Underlying FDR's attitude was the feeling that the end 
of the European imperial system was inevitable and that the true question was how soon it would collapse. ${ }^{74}$ FDR believed that solving the colonial problem could wait until the United Nations was up and running. ${ }^{75}$

At the same time, the Europeans were in a state of flux. The bulk of the European empires ran from Southeast Asia to the Middle East and included nearly all of Africa. These empires, and the process of colonial rule, had extended from the Fifteenth Century until the time of the First and Second World Wars. Before the conflicts, the Europeans had appeared invincible. By the end of the Second World War, this illusion had been shattered. ${ }^{76}$ As the primary war raged on, the European powers either lost control of their colonies, such as when Japan seized Indochina and Indonesia, or became engrossed in the homeland's life and death struggle. ${ }^{77}$ These circumstances merged with the insight within the colonies that the imperial powers were not omnipotent and produced the sense that the burden of imperial rule could be overthrown. Nationalist movements had been sowing discord during the interwar years and their impact only strengthened by the end of the second global conflict. In the aftermath of the Second World War, the Europeans' weakened condition provided these newly empowered natives an excellent opportunity to achieve independence. ${ }^{78}$ During the war, even the intact British received extraordinary pressure from its most well-established and critical colonies, India and Egypt, to break from the British Empire. ${ }^{79}$ In the ever-troublesome Middle East, countries also sought independence and by the end of the war, a hundred thousand or more Jews were moving to Palestine, which inflamed the situation even more ${ }^{80}$ Thus, Truman faced a situation of European empires in flux when he assumed office as the war ended. 


\section{CHAPTER IV \\ HARRY S. TRUMAN}

\section{EARLY PRESIDENTIAL PHILOSOPHY}

By the time Truman, "a farmer boy from Jackson County," assumed the presidency he had been Vice-President for less than a hundred days. Truman had met FDR on a few brief occasions and did not know Roosevelt's plans and personal policies. ${ }^{2}$ Truman had no knowledge about major programs, such as development of the atom bomb, and did not have the "need-to-know" required to enter FDR's secret war center, the White House Map Room. ${ }^{3}$ Truman told his daughter in private that Roosevelt, "never did talk to me confidentially about the war, or about foreign affairs or what he had in mind for peace after the war." Moreover, FDR failed to outline his overall foreign policies and objectives to his staff. After many years in office, Roosevelt had consolidated military and diplomatic decision-making into his own hands. Even primary advisors such as Joseph Davies, former Ambassador to the Soviet Union, and close friends like Harry Hopkins knew only bits and pieces of the overall design. No one knew FDR's grand strategy and so no one could advise Truman on what to do next. ${ }^{5}$ A Washington Post article at the time summed up the military and foreign policy situation facing Truman by saying, ". . President Truman comes into this gigantic assignment under a handicap."6

Nevertheless, in the beginning Truman tried to act as his predecessor would have 
wanted. Some people claim that he would point at FDR's image in the Oval Office and say, "I'm trying to do what he would like."" Other close advisors routinely heard the new President ask himself "I wonder what Roosevelt would have done?" or "Would he think this was the right thing?"8 This desire to emulate FDR is not surprising since Truman had grown up believing in the idea of great men molding history. He recounted to others that his favorite book as a boy was about notable figures that shaped history, such as Moses, Caesar, and Genghis Khan. In a letter to a reporter, Truman explained his historical perspective as "real history consists of the life and actions of great men who occupied the stage at the time." 9 FDR had been the President for twelve years, much longer than any other American President who had held office. He led the country during the Great Depression and steered the course through the Second World War. For most Americans Roosevelt embodied the essence of the United States government. Truman wanted to follow his example. Nonetheless, Truman knew that he was unprepared to take over making foreign policy decisions and the running of the United States. The contrast between Roosevelt and Truman is marked when one considers that Truman was a farm lad from Missouri while Professor Dallek describes FDR as "the most cosmopolitan American to enter the White House since John Quincy Adams in 1825."10 In May 1945 Truman said, "I am the last man fitted to handle it and it happens to me." All the same, by October 1945 Truman made a speech that cited foreign policy aims, which sounded both anti-colonial and Rooseveltian in its pronouncements,

1. We seek no territorial expansion .... 2. We believe in the eventual return of sovereign rights and self-government to all peoples who have been deprived of them by force. 3. We shall approve no territorial changes ... unless they accord with the freely expressed wishes of the people concerned. 4 . We believe that all peoples who are prepared for self-government should be permitted to choose their own form of government. ${ }^{12}$ 
Truman also believed, as had Roosevelt, that the United States should be more involved in the postwar world. ${ }^{13}$

\section{FDR / HST DIFFERENT PERSONALITIES}

The differences between Truman and FDR are well known but a comparison may help understand Truman's style in dealing with the colonial question. First, FDR was a politician who saw the world in various shades of gray, a grand thinker who could make amazing intuitive leaps. ${ }^{14}$ Conversely, Truman's background and training gave him a different temperament and worldview.

Harry's schooling conspired with his moral and religious upbringing to leave him with the conviction that personal behavior, and by extension that of societies and nations, should be guided by universally understandable Victorian maxims, that distinctions between good and evil were unambiguous, that there were few gray areas in life. ${ }^{15}$

Compared to FDR, Truman was a mental plodder whose strength lay in his dogged study and perseverance at understanding the many faces of complex problems. Even Secretary of State Dean Acheson a real admirer of Truman, once said when comparing Presidents Lyndon B. Johnson and Truman that "They were cut from the same cloth. They both come from border states ... but Johnson has an A mind and Truman a B mind."16 According to Miscamble, the thirty-third President had a "... distaste for complexity and his preference for clear and fixed standards along with his hesitation to engage in creative or conceptual thinking made him susceptible to a very straightforward approach to policy making." 17 Not prone to making hasty decisions Truman was a cautious thinker who 
dealt with problems linearly rather than addressing them within an interlocking framework of policy considerations. The consequence of Truman's method of handling problems was that American foreign policy decisions appeared to be haphazard instead of employed in a consistent, systemic manner. In the final analysis, Truman's linear thinking makes it difficult for a researcher to perceive the President's overarching philosophy when considering ideas such as anti-colonialism and when examining a range of foreign policy decisions.

In the end, the biggest difference between the two men was one of management style. FDR manipulated situations and often put off making choices until a solution presented itself or something forced a decision. On the other hand, Truman wrestled with a problem until he had come to a decision about it. This difference in style enhanced the image of FDR as a detached intellectual while Truman seemed blunt and plainspoken. Truman's aura of brusque individuality was deceptive though, since he sought the counsel of able advisors and experienced men, relying upon them to help bridge the gaps in his own knowledge about international affairs. ${ }^{18}$

Unlike FDR's well-known compulsion to centralize policy-making in his own hands, Truman was more than willing to share the process with his advisors and department heads, especially in the beginning of his administration. A good example of these differences in management techniques concerns the conference to discuss the formation of the United Nations held in San Francisco shortly after Truman assumed office. Prior to his death FDR had been planning to lead the American delegation. Truman decided to leave the responsibility for running the delegation to the group's leaders. He provided personal instructions but was willing to delegate duties to others whom he thought were 
more proficient in the foreign affairs arena. ${ }^{19}$ This style of management makes it difficult at times to pin down Truman's true feelings concerning a range of foreign policy decisions that occurred on different dates. Throughout Truman's time in office, this result was true of administrative decisions that did not reach the top tier of foreign policymaking and therefore did not require the President's personal pronouncement. For example, Truman had a deep dislike for the Spanish government of Francisco Franco and was hostile to the idea of congenial relations between the dictator and the United States. Nevertheless, when the Departments of State and Defense instituted normal relations and laid the groundwork for military bases in Spain he begrudgingly went along with the Departments' earlier decisions. ${ }^{20}$

While there are many differences between the personalities of Roosevelt and Truman, they shared some common traits. Both possessed an idealistic streak concerning the future of humanity. ${ }^{21}$ In Truman's case, one might attribute this idealism in some measure to his background, temperament, or his Masonic training. ${ }^{22}$ An example came in one 1940 speech concerning civil rights where he used the "brotherhood of man" concept common to Masonic teachings. ${ }^{23}$ Not all Masons practice that philosophy; yet, Truman seemed to when he said, "I believe in the brotherhood of man, not merely the brotherhood of white men but brotherhood of all men before the Law."24 Regardless of the source of his worldview, Truman does seem to be in agreement with the traits ascribed to FDR when conversing on such things as idealistic support for the United Nations, trusteeship and anti-imperialism. ${ }^{25}$

Another quality that Truman had in common with Roosevelt was the belief that the treatment of foreign affairs is the same as local and national politics. ${ }^{26}$ While Truman 
tended toward a stark black and white view of the world, he was also a product of the corrupt Pendergast political machine that created a seasoned and pragmatic politician

who understood and employed the fine art of political compromise. ${ }^{27}$ In Truman's world, the facts of life dictated that some give and take would be required regardless of whether one was dealing with Tom Pendergast, Joseph Stalin, or Winston Churchill. This view of politics allowed both Presidents to compromise on some objectives in order to achieve other, greater goals but it did result in some inconsistencies and ambiguities in their foreign policies. These uncertainties are what allow various interpretations as to their intent and outlook about colonialism. Therefore, one must not only look at individual decisions but also at the rhetoric and underlying source of their philosophy.

\section{WILSONIAN FOREIGN POLICY}

In addition to Roosevelt, Truman, like FDR before him, gained inspiration from President Woodrow Wilson. During World War One Truman saw service as a young artillery officer and held a life-long belief that he had fought for Wilson's Fourteen Points and its League of Nations. ${ }^{28}$ Truman once said, "How much misery and suffering the world would have been spared if we had only followed Woodrow Wilson!"29 Truman supported Wilson's idea of a League of Nations and labeled Congress' rejection of the concept and refusal to accept the nation's rightful role as a world power a fatal error. During the mid-1930s, he deviated from Wilson's idea of internationalism for a short time when he supported popular legislation devised by isolationist Gerald Nye. Senator Nye's Committee had published a report, which asserted that arms dealers had unduly 
influenced American foreign policy prior to the First World War and an outpouring of isolationist sentiment resulted. Truman later called his support of Nye and his isolationist legislation, designed to keep the United States out of the troubles brewing in Europe, a momentary error in judgment. Furthermore, Truman described Nye as “... a demagogue senator from North Dakota." ${ }^{30}$ Truman went on to support FDR's interventionist policies as way of making up for past failings. ${ }^{31}$ He set forth his position in speeches that said, "I have said time and again that Almighty God intended this great Nation to be the leader of what is right and what is well for the world, and He indicated that in 1920 after the First World War. But there were certain men who felt that that was not the proper thing to do, and then we had to go through World War II." ${ }^{32}$ When there was talk of the United States withdrawing from the world scene after the Second World War Truman argued that Americans were too smart to embrace, once again, isolationism. ${ }^{33}$ This conviction dovetailed with FDR's rather nebulous vision of a world organization in which the United States, Britain, Russia and China would work to secure world peace while expanding free trade around the globe. ${ }^{34}$ Later, Truman would say in his memoirs, "I still believe in Woodrow Wilson's philosophy of self-determination." ${ }^{\text {35 }}$ This attitude, linked with his desire to follow FDR's foreign policy, influenced Truman's outlook on the world order and the role of both the United States and the European empires.

\section{ANTI-IMPERIALISM}

A point that Truman made in speeches was that the United States' goal in World War Two was, “... for peace and for the welfare of mankind. We are not fighting for 
conquest. There is not one piece of territory or one thing of monetary nature that we want out of this war," ${ }^{, 36}$ As a display of Truman's beliefs one can point to the fact that the Philippines received independence from the United States on 4 July 1946 despite the opposition of some members of Congress and military leaders who felt that it was far too soon. ${ }^{37}$ Furthermore, his desire to promote freedom and democratic principles extended well beyond the shores of the United States. In one of Truman's final speeches he spoke of the inevitable demise of European empires and the end of their colonial rule with pride, "Just in the years I have been President, 12 free nations, with more than 600 million people, have become independent: Burma, Indonesia, the Philippines, Korea, Israel, Libya, India, Pakistan and Ceylon .... These names alone are testimony to the sweep of great force which is changing the face of half of the world." ${ }^{38}$ Of the new postwar world that Truman imagined he said, "The old imperialism-exploitation for foreign profit-has no place in the concepts of democratic fair dealing." 39 Truman helped the growth of freedom within the European empires through a variety of methods. Within these actions, one can find evidence of his dislike for colonialism and support for the right of self-rule.

As previously discussed, Truman was not an isolationist as one would probably have assumed based on his background, rather he was pro-Open Door in his outlook. $\mathrm{He}$ described his feelings on the subject saying, "We are moving toward our goal of world peace in many ways .... The most important efforts which we are now making are those which support world economic reconstruction .... To restore world trade we have recently taken the lead in bringing about the greatest reduction of world tariffs that the world has ever seen." ${ }^{40}$ He was a long-time supporter of free markets and when the 
Trade Agreement Act of 1934 passed the Congress, he called it a major legislative feat. ${ }^{41}$ Truman believed that the 1920 s' restriction of trade, with its tariffs and other barriers, was a terrible thing for the world. He perceived the problem as being that leaders of government and commerce were acting to protect their own producers but, in turn, they excluded others who depended upon that trade to buy their products. As global trade slowed, rather than trying to stimulate it, nations instead practiced trade reprisals and even increased the restrictions such as Britain's Imperial Preference System. ${ }^{42}$ Truman put it this way, "They ignored the fact that the whole world suffers when each country tries to make itself a tight little island with high walls all around." ${ }^{, 43}$ In large measure the economic problems of the 1920 s and 1930 s, and the suffering that occurred during the Great Depression, drove his anti-imperialist sentiment quite apart from his philosophical reasoning. In 1944, Truman joined with other Senators to call for more internationalism and free trade. He and his fellow Senators cautioned that the harmony of the postwar world "depends on the abandonment of political nationalism and economic imperialism and autarchy." ${ }^{, 44}$ President Truman's address about America's foreign economic policy, given at Baylor University on 6 March 1947, summarized his belief that the restrictive trade practices of the 1930s led not only to the Great Depression but also to a de facto economic war waged with tariffs and trade restrictions prior to the start of the shooting war. ${ }^{45}$ In particular, he blamed Nazi Germany and the British Empire for being the main practitioners of the malicious form of economic warfare that destroyed the world's economy. ${ }^{46}$ He concluded the speech by presenting the idea that international free trade, orchestrated by a globally minded rather than an inward looking United States, was the true salvation for the future. ${ }^{47}$ He did more than just pay lip service to this view when he 
and his administration fought the Republicans to protect the General Agreement on Tariffs and Trade (GATT). In a speech after a political battle ended in approval of The Reciprocal Trade Agreement Extension Act of 1949, which allowed the extension of the trade deals in the GATT, Truman said that the Act "extends . . . our trade agreement program, free of the crippling restrictions imposed on it in 1948 by the $80^{\text {th }}$ Congress. ${ }^{, 48}$ In the same speech, he also talks about recent agreements made with Canada and Great Britain to open the Commonwealth to outside trade. ${ }^{49}$ Truman had backed all the efforts at the 1944 Bretton Woods Conference, most notably the GATT accord and the proposals to establish an International Trade Organization (ITO), International Monetary Fund (IMF) and World Bank. ${ }^{50}$ Spurred by the successful launch of the IMF and World Bank Truman remained steadfast in his continued support for the ITO proposal until finally, in 1950, he deemed passage impossible.

Truman's legislative efforts concerning GATT and the ITO were not his only attempts to end the protectionist trade practices of European imperial rule. In the spirit of free trade, Truman used his prominence to call upon the nations of the world to "... devise their economic and financial policies to support a world economy rather than separate nationalistic economies." 51 He also used the economic might of the United States to provide aid and extend Lend-Lease programs to England since "Extension of this credit will enable the United Kingdom to avoid discriminatory trade arrangements of the type which destroyed freedom of trade during the 1930's."

Truman's anti-imperial attitude enjoyed popular public support especially when the target was the British Empire, a point not lost on this perceptive politician. Following the war, anti-British feelings lurked within America's psyche. ${ }^{53}$ Many Americans felt that 
the British, along with the other European allies, were not sufficiently grateful for the support they had received during the war. Additionally, they suspected that any aid provided to the war-ravaged European nations would enable the European empires to reestablish themselves in the postwar period. ${ }^{54}$ One example of such an attitude was a telegram in 1947 from a private citizen, Jack Hess, to President Truman expressing his anti-British perspective, "IF BEVIN WANTS TO SHARE THE FT KNOX GOLD WITH US HOW ABOUT OUR SHARING ENGLANDS COLONIAL EMPIRE WITH THEM HERES ONE VOTER REPRESENTING A GROUP WHO IS AGAINST IT" [emphasis from original]. ${ }^{55}$ A poll conducted in February 1945 found the majority of Americans thought that the United States would have more problems with imperialist Britain than Communist Russia. ${ }^{36}$ At the same time, the State Department and other governmental agencies were more than willing to renew efforts to end the British Empire and obtain "...preferential trading rights in British colonies." National Advisory Council on International Monetary and Financial Problems highlighted ongoing efforts by the State Department to maintain the open markets conceded in exchange for a loan by Britain's Ambassador to the United States, Lord Halifax, in 1945. At that juncture, Lord Halifax's letter had prohibited Britain and her colonies from trade discrimination against external countries. ${ }^{58}$ American's fundamental distrust of British imperialism, linked with the Open Door philosophy embedded in the American character, served to keep the issues and rhetoric about colonies in the spotlight and part of the political vocabulary of the time. ${ }^{59}$ Thus, it seems reasonable that Truman considered the issue of ending Europe's historic stranglehold on undeveloped parts of the world a matter of right and wrong. In Truman's own words, "We wanted to give them a 
better sort of government and do away with colonialism."60 All the same, one cannot ignore the practical aspects of Truman's Open Door policies that allowed American businesses valuable economic access to foreign markets. Nonetheless, just because the United States profited by lowering tariffs this result does not refute the fact that Truman thought ending imperial protectionist trade practices would benefit all of humanity and promote freedom in the former colonies. ${ }^{61}$ In the context of supporting global open trade, Truman's rhetoric and actions show continuity between his position and FDR's and fit with his desire to follow the wishes of the former President.

Truman declared, "I had always been opposed to colonialism. Whatever justification cited at any stage, colonialism in any form is hateful to Americans. America fought her own war of liberation against colonialism and we shall always regard with sympathy and understanding the desire of people everywhere to be free of colonial bondage., ${ }^{, 62}$ Truman's rhetoric, here and elsewhere, makes it clear that, for him, the issue of colonialism was black and white without the normal ambiguities found in foreign affairs. Yet, implementing this philosophy would prove to be much more complex, in fact well nigh impossible, in the face of competing goals and ideas. In order to provide a structure for Truman's straightforward beliefs on colonialism, and to help him navigate the unfamiliar and convoluted art of diplomacy he required assistance and advice.

\section{TRUMAN'S ADVISORS}

To comprehend the foreign policy differences between Roosevelt and Truman it is important to understand their familiarity with the subject. FDR had been in office a long 
time and his vast experience and background knowledge of people and prior events makes the contrast between him and his newly elected Vice-President even more blatant. The inexperienced Truman moved into the post overnight and did not even have the normal two-month preparation period that President-elects routinely enjoy. In fact, Truman was Vice-President only eighty-two days before Roosevelt died. Of those eighty-two days, FDR was in Washington D.C. with his new Vice-President for just thirty days. ${ }^{63}$ Truman's selection as the Vice-Presidential nominee had been politically expedient and no closeness existed between the two men. There was nothing in their relationship that caused the secretive FDR to embrace and confide in Truman. ${ }^{64}$ For instance, when FDR and his closest advisors went to Yalta for his last conference with the Allies in February of 1945 he left Truman behind to tend to ceremonial duties and preside over the Senate. In addition, none saw a need to invite Truman to attend any high level foreign briefings at the White House during his brief period as Vice-President. ${ }^{65}$

Totally unprepared, Truman was plunged headlong into a situation where he had to address the multiple activities and emergency situations of a nation at war while still learning how to do his job. ${ }^{66}$ Early on, he told one of his cabinet members, "I know nothing of foreign affairs and I must acquaint myself with them at once." 67 Additionally, he had no advisors or trusted contacts of his own about matters of foreign policy prior to taking over in the White House. ${ }^{68}$ Truman's lack of experience and preparation forced him to rely heavily on FDR's advisors. ${ }^{69}$

Truman's personality was such that he felt obligated to consider all available facts and then coordinate his decisions. This propensity reinforced his reliance upon advisors. In spite of later gaining a reputation for decisiveness, Truman's policy pronouncements 
were “... the product of careful political or diplomatic planning and group consensus, not individual whim.,70 Thus Truman's style forced him to rely far more heavily on foreign affairs advisors than had Roosevelt. ${ }^{71}$ This reliance on advisors was especially true at the beginning of his time in office. The first day on the job, he called in Edward Stettinius, the Secretary of State, to prepare primers covering all foreign policy issues and the upcoming United Nations' Conference that was to be the first item in the queue. ${ }^{72}$ Therefore, to understand Truman's foreign policy actions one must also understand his advisors and their positions. While President Truman's advisors were many and varied, the following agencies and people had the most influence and impact upon shaping the President's official colonial position.

\section{TRUMAN'S VIEW OF THE STATE DEPARTMENT}

Truman belittled the State Department membership as a bunch of pretentious, selfserving elitists. ${ }^{73}$ He referred to State Department personnel as the "striped pants boys. ${ }^{~} 74$ Nevertheless, he relied upon them either through necessity or, at least in some cases, close personal relationships that developed based on respect and admiration such

as the associations he had with Secretaries of State George Marshall and Dean Acheson. ${ }^{75}$ When pressed by reporters about foreign policy decisions, Truman explained that he did not want to follow FDR's method of internalizing foreign affairs rather, “. . . the State Department is set up for the policy of handling foreign policy operations, and the State Department ought to take care of them." ${ }^{\prime 76}$ The early State Department's goals were familiar they "... wanted the British to reform their imperial practices, dissolve the 
sterling bloc, accept full convertibility of the pound into dollars, and adhere to the principles of open and nondiscriminatory trade." 77

An example that shows pursuit of these goals comes from one of Truman's early State Department advisors Loy Henderson, Director of Near Eastern Affairs, who articulated the Department's position on European colonies in the Middle East. Henderson argued that the United States had failed in 1919 with the establishment of the League of Nations and had failed again in stopping the French and British from securing colonies in the aftermath of the First World War thereby closing those markets to outside competition. He put forth the opinion that the United States should assert itself and prevent a similar situation from developing in the Middle East with the Soviet Union and European powers by pursuing an Open Door policy in the region. ${ }^{78}$ The Truman administration adopted this approach for future dealings in both the Middle East and Iran. The next set of advisors would turn out to be more problematic.

Besides officials in the State Department, Truman also received advice early in his tenure on the issue of colonialism from another profession, members of which he both maligned and praised, Generals. ${ }^{79}$ According to an early-unpublished draft of Truman's memoirs, in May and June of 1945 Ambassador to China, Patrick J. Hurley, a former Army General, and General Albert C. Wedemeyer, Commander of American forces in China provided Truman an assessment of the true situation in the Far East. They also provided some rather pointed recommendations on how to handle the imperialist powers of Europe. ${ }^{80}$ They included the following,

The paramount political issue in Asia for many years has been the issue between Democracy and imperialism. We supported Chinese Democratic aspirations against the imperialism of Japan. The question is will we now permit British, French and Dutch imperialists to use the resources of the American democracy to 
reestablish imperialism in Asia .... The appointment of Lord Louis [Lord Louis Mountbatten, British Supreme Allied Commander South East Asia Theater] or any other imperialist as Commander in China would constitute nullification of American principles and achievements in China .... All the Imperialist nations have done has been in an endeavor to recover their colonial possessions largely by the use of American and Chinese resources and reestablish the prestige of imperialism. $^{81}$

This same series of cables from Hurley include particulars on Hong Kong and Indochina.

In the case of Hong Kong Truman received the following advice:

We have two major pressing controversies affecting the present military situation and the future of democracy and imperialism in Asia that are still unsettled .... Last March $8^{\text {th }}$ President Roosevelt said to Wedemeyer and me ... he still insisted that the British return Hongkong to China. Roosevelt said that if Churchill refused to agree to this he would go over Churchill's head to the King and to Parliament .... Churchill told me that Hongkong would be returned to China only 'over my dead body' ... . My opinion is that if we have a firm policy on Hongkong Britain will yield ... in China we may find that another great power that claims to be anti-imperialistic may adopt imperialism as a policy ... to combat British imperialism in China .... You could also say that no credit or additional gifts at the expense of the American taxpayer [more Lend Lease] would be given to Britain until Britain shows a more understanding attitude towards the American policy on Hongkong and towards Democracy the world over. I think you would find Britain still amenable to reason. ${ }^{82}$

Later Hurley goes on to discuss Indochina, another colonial issue that would cause angst

for the United States for decades to come:

1944 President Roosevelt directed me to inform General Wedemeyer that no policy would be promulgated on Indochina until after a forthcoming combined staff conference. The President also directed me to keep him informed as to activities of British-French-Dutch missions in Southeastern Asia. The President had already discussed the Indochina situation with me personally. He was not pleased with the fact (1) that Vichy French of Indochina had collaborated with Japan (2) he was in favor of establishing a United Nations or international trusteeship under whose care and tutelage Indochina could secure independence according to the principles of the Atlantic Charter. Neither General Wedemeyer nor myself has ever been given a definite written directive on Indochina political policy .... The French Ambassador and military mission have become exacting in their demand for American support for French activities in Indochina. The French demand American war supplies as a matter of right .... In my last conference with President Roosevelt I informed him ... the French, British and Dutch were cooperating to prevent the establishment of a United Nations Trusteeship for 
Indochina. The imperialist leaders believe that such a trusteeship would be a bad precedent for the other imperialistic areas in Southeast Asia. ${ }^{83}$

Hurley goes on to explain that he had requested written instructions from FDR with respect to Indochina and was renewing that request with the new President. Roosevelt's only response to Hurley's request for clear and explicit directives had been that the San Francisco Conference would set up some kind of trusteeship program under the auspices of the United Nations who would help develop the trustee and grant them independence with they were ready. Hurley sought clarification about the apparent change by the United States at the San Francisco Conference where the old imperial powers received trustee control and not the United Nations. Since this result contradicted, what he had understood from FDR Hurley was anxious to know the current guidelines. He had queried the State Department but had not received any clarification. Hurley said the troubling aspect of the situation was that Lord Mountbatten, Commander South East Asia Theater, was already using Lend-Lease and numerous other American resources and supplies to reestablish the French in Indochina. ${ }^{84}$ Truman replied in June 1945, "I fully appreciate the frank statement of the military situation in China ... and your equally frank estimate of the world wide political intentions of those European Nations that are allied with us in this war. You may be assured that these matters are receiving full consideration in America's planning for the future .... Many of the questions presented in your above noted communications may be discussed in the forthcoming tripartite conference. ${ }^{n 55}$ As seen from this series of messages, Truman was aware early on about the imperialist intentions of the European powers in Asia, FDR's position on the subject, the use of American resources to augment English and French efforts in Indochina and the lack of clear guidance for those in the field. In this case, the new President did not 
heed the advice as he and his administration moved into the immediate postwar period and the beginnings of the Cold War. While Hurley provided some advice on foreign policies and issues dealing with colonial territories of the European empires, other betterknown advisors also weighed in on the subject to varying degrees. First examined are the Secretaries of State that served as Truman's primary advisors on foreign affairs.

\section{TRUMAN'S SECRETARIES OF STATE}

Unlike the long-serving Roosevelt, who ran his own foreign policy and had little need for a Secretary of State other than to oversee the State Department's bureaucracy, the less experienced Truman relied on the men who occupied that position. In fact, Truman ended up appointing four different men to the post while in office. The first two, Edward Stettinius and James Byrnes had limited influence on the new President. Truman wrote of Stettinius, his first Secretary of State, as "a fine man, good looking, amiable, cooperative, but never an idea new or old." ${ }^{86}$ Stettinius had limited experience in the job since Roosevelt appointed him late in 1944 as caretaker for the department. Truman replaced Stettinius within a few months with Byrnes, his personal candidate for the office. ${ }^{87}$ Byrnes had served as an unofficial sub-president for domestic affairs during Roosevelt's third term and he commanded such respect around the nation's capital that he warranted some cabinet level position in the new administration. Truman's association with his second Secretary of State was initially cordial even though Byrnes had competed with Truman for the job as Roosevelt's Vice-President in the 1944 election. ${ }^{88}$ Nevertheless, their relationship soured over time. Byrnes' obvious belief that he was 
much better qualified for the job of President than Truman, his subsequent mediocre running of the State Department and his disregard of Truman's wishes finally ended with his systemic marginalization. He submitted his resignation in early $1947 .^{89}$ The next two Secretaries of State had different associations and long-term relationships that would fundamentally influence Truman's foreign policies and related issues of colonialism.

Truman's third Secretary of State, who he described as "one of the most astute and profound men I have ever known" $" 90$ was the universally admired General George C. Marshall. Truman always treasured Marshall's friendship and this closeness produced a great rapport between the two men during both the Four-Star General's time at the State Department and later when he took over the Department of Defense. ${ }^{91}$ For example, when Marshall assumed the role as Secretary of State Truman said, "I am hoping that Gen. Marshall will take the striped pants boys for a ride. ${ }^{.92}$ Truman often referred to Marshall as one of the greatest Americans ever and never had a disparaging remark to say about him during or after his time in office. ${ }^{93}$ One of the few points of contention between the two men was on an issue of colonialism. Marshall opposed ending the British mandate in Palestine to allow the founding of a Jewish State in the region. Marshall felt that the presence of an official Jewish country in the Arab-dominated oilrich region would be a source of unending conflict and a threat to the United States' longterm security. ${ }^{94}$ Despite this disagreement, Truman and Marshall worked well together and fought to end American isolationism. In fact, as time went on Truman went well beyond what FDR had envisioned during the Second World War as America's role in the postwar world. ${ }^{95}$ A close aide, Clark Clifford, said that the new President had one great aptitude and that it "was Harry Truman's capacity to grow." 96 
Truman and his evolving foreign affairs team came up with a number of unheard of diplomatic policies. Some of these policies affected the issue of European colonialism. For instance, Truman was talking about the Marshall Plan and the issue of granting freedom to lands under colonial rule when he said, "In all the history of the world ... we are the first great nation to create independent republics from conquered territory, Cuba and the Philippines. ${ }^{97}$ Truman also had serious disagreements with Churchill in the early development stages for the Marshall Plan according to Joseph G. Feeney, an assistant to Truman in the White House. Truman had explained that the British government and Churchill particularly, did not like the plan for they sensed that it would allow the United States to interfere in their internal affairs. Feeney described the situation, “. . . they met quite frequently . . But each time, they'd have an argument, and a strong one, and Mr. Churchill was not very happy about the Marshall plan. He wanted to keep the British Empire as it was, and he wanted nothing to interfere with it. Moreover, there was some talk at that time about India, you know, breaking away from the empire. Mr. Churchill was violently opposed to that -- violently opposed -- at that time." 98 The Marshall Plan actually helped the European powers with their colonial holdings by providing supplies that cost millions of American dollars that the empires then administered to the locals. ${ }^{99}$ Management of the Marshall Plan by the State Department in reality produced an American policy that placed the welfare of European powers, and restoration of their former worldwide eminence, ahead of concerns about other regions of the globe. ${ }^{100}$

The next close advisor examined was Truman's longest running Secretary of State, Dean Acheson. Acheson's influence on Truman as his chief advisor on foreign policy is 
well known and their relationship with respect to foreign affairs may even have eclipsed that of General George Marshall. Their rapport far exceeded any bond that Truman had established with Edward Stettinius or James Byrnes. Initially, along with other senior State Department advisors such as W. Averell Harriman and Robert Lovett with their Ivy League backgrounds, this key advisor seemed to be an Anglophile and by inference proimperialist. ${ }^{101}$ Acheson even admitted that he was unabashedly supportive of the British as a people and said, "My own attitude had long been, and was known to have been, proBritish." 102 Moreover, Acheson often stated he believed that American and British aims were the same and in the best interests of Western Civilization. ${ }^{103}$ However, Acheson's feeling about Great Britain and any possible collusion with friends in the British government to influence Truman was blunted by the fact that when he became the United States' senior diplomat the British were under Labour Party control. That same Labour Party had been trying for years to divest itself of some of the more bothersome colonies and reestablish itself as the heart of a Commonwealth of Nations. ${ }^{104}$ Besides, Acheson said in reference to a question about special treatment for Great Britain, "Of course a unique relation existed between Britain and America-our common language and history insured that. But unique did not mean affectionate. We had fought England as an enemy as often as we had fought by her side as an ally." ${ }^{105}$ More relevant to the United States' colonial policy and the Truman administration was his perpetuation of the belief that Europe was the centerpiece of American foreign policy. John Cady, an associate in the State Department, described him as conservative and European oriented. ${ }^{106}$ This Eurocentric outlook would not produce rejection of the Truman White House's anti-colonial stance but would instead marginalize its importance. ${ }^{107}$ 


\section{ELEANOR ROOSEVELT}

Eleanor Roosevelt was one of the few champions for the rights of people in the various colonies around the world who advised Truman regularly. By this time, she was a powerful Democrat Party elder who could mobilize voters on behalf of candidates. Many Americans admired her for her social causes and considered her the public keeper of FDR's legacy. These attributes made her an influential person in the nation's capital and across the country. She regularly received invitations to important events around the world, the national press often quoted her, and she had direct access to key governmental leaders to include the President. ${ }^{108}$ Eleanor Roosevelt was a person that politicians disregarded at their peril. As a show of respect, and in recognition of her universal popularity, ${ }^{109}$ Truman had appointed the former First Lady as a delegate to the United Nations General Assembly in 1946. ${ }^{110} \mathrm{He}$ also developed a close friendship with her based upon mutual respect and kept up regular correspondence with her throughout her

life. She and Truman ended up exchanging 254 private letters from 1945 to $1960{ }^{111}$ She was always ready with advice in those letters and scolded Truman one time for wasting time writing a lengthy letter in longhand when newly in the job and feeling overwhelmed by the position. In the same letter, she told him to trust in his own counsel over others around him. ${ }^{112}$ Later, at a low point in the Presidency, she told friends that Truman's problem was that "he had the wrong sort of people around him."113 Even so, she had no compunctions about sending Truman her own advice concerning foreign affairs.

In a series of letters to Truman in the White house a number of times she raised the 
issue of rights for people subjected to colonial rule and the general issue of imperialism. Truman, in turn, talked to her about his efforts in the international arena, for instance assuring her that he was trying to draw the British out of their imperialistic Sterling Bloc and into more open trade practices. ${ }^{114}$ In a 1947 letter, Eleanor Roosevelt told Truman that the United States should not assume the imperialistic policies of Churchill in the Near East for it would undermine the spirit of democracy in the region. She also warned Truman of the future failure of French imperialism, "France has been so long in North Africa and accomplished so little in raising the standard of living and in giving the people education that I do not know how long they can hope to keep their power unchallenged." "115 While serving in the United Nations she warned Truman that,

The race question has become a very vital one since much of the feeling is that of the colored races against the white race. We are classed with the colonial powers as having exploited them because our businessmen in the past have exploited them, so we have no better standing than the United Kingdom or any other colonial power. I think we have to reckon with this in our whole world outlook because we will need friends badly and it surprising how few we have in spite of all we have done for other people in the past. ${ }^{116}$

She also voiced concern that Acheson and other advisors were too sympathetic to the British cause and urged Truman to take care. ${ }^{117}$ She was also able to use these advisors at other times to influence indirectly Truman to side against the colonial desires of the European powers. For instance, she urged Acheson in the early 1950s not to yield to French pressure in Tunisia when the French were trying to hold onto that colony in spite of international press. ${ }^{118}$ Lastly, on the related concept of her husband's Four Freedoms she was an exceptionally active advocate for the United Nations' Declaration of Human Rights. ${ }^{119}$ She pressured Truman about the declaration when the vote was coming up for ratification in the United States and Truman approved of her casting the United States' 
affirmative vote for the 1948 Declaration of Human Rights that indirectly supported an end to colonialism. ${ }^{120}$ Eleanor Roosevelt was perhaps the single most successful of the Truman advisors in bringing the colonial issue to the President's attention. However, none of his closest foreign policy advisors, Acheson or Marshall, supported the return of European imperial domination to the international scene. Nor did they appear to argue that there was a need to perpetuate colonial rule. However, the Euro-centric view of the world found in Truman's State Department and among his key advisors sometimes worked to the disadvantage of other regions of the world. These same State Department officials and Ambassadors backed policies to break the European empire's economic stranglehold on their colonies and expressed support for FDR's anti-colonial outlook. Truman drew upon the counsel of these foreign policy advisors and it seems apparent that no one backed the permanent reinstatement of the colonial empires. Other events also conspired to bring the issue of imperial rule up in the course of policy-making in the administration.

\section{$\underline{\text { POTSDAM }}$}

At the Potsdam conference from 16 July to 2 August 1945; Admiral Ernest King, an early and influential advisor said of Truman, "Watch the President ... This is all new to him but he can take it." ${ }^{\prime 21}$ Even before the start of the conference, Churchill was pressuring Truman to occupy Yugoslavia. Truman's reply was that the territorial issues needed to be settled in an organized manner unlike the post-First World War "uncontrolled land-grabbing." 122 Years later Truman wrote Dean Acheson that in coming 
to the conference he had wanted to coordinate with the other powers and arrange benevolent approaches on the subjects of free waterways, and self-governance for all enemy nations, conquered lands and territories. ${ }^{123}$ Additional discussions beyond spheres of influence and atom bombs ${ }^{124}$ did occur but not in the idealistic tones that Truman had hoped. For instance, Churchill tried to secure American support for imperial interests by offering basing for American forces in colonial ports around the world. As Churchill said, "We could add 50 percent to the mobility of the American fleet."125 As for former Italian colonies, from the beginning Churchill had expressed a desire for the British to maintain control of those regions until final disposition..$^{126}$ The destiny of Libya, Eritrea and Somaliland remained vague because the conference attendees decided that their fate should be resolved as part of a later 1947 peace treaty for Italy. ${ }^{127}$ During the later treaty talks, the United States' position was that the colonies should become British-supervised trusteeships while the French wanted to return the colonies to Italian control rather than let the British administer them. ${ }^{128}$ As for Truman's stance at the treaty talks, a senior State Department official observed that Roosevelt and Truman's position regarding to the Italian colonies was that they should be trusteeship territories and eventually receive their independence. ${ }^{129}$ Libya would gain its independence in 1951 but Somaliland would have to wait until $1960 .{ }^{130}$ Participants also discussed the disposition of Indochina, which forces of Japan still occupied at the end of the war. The plan was to hand over the northern part to the Chinese and the southern to the British who would then turn it back over to France, a fellow European empire. ${ }^{131}$ This arrangement was a natural outgrowth of FDR's earlier agreement to let the British take over Theater Command in the region and therefore not considered a major policy change by the new President. In a similar 
vein, the United States and Soviet Union would divide control of Korea. These decisions seemed to be a practical and temporary solution as Japanese forces departed the battlefield but no one could foresee the lasting effects they would have for United States policy. These choices put a pro-colonial face on Truman's foreign policy though in actuality, the Truman administration was pinning its hopes on the United Nations as the forum to resolve such international problems in a rational and peaceful manner.

\section{UNITED NATIONS}

Another early indicator of President Truman's intentions concerning European colonialism was the establishment of a new world body to replace the failed and ridiculed League of Nations. In fact, Truman's first foreign affairs decision on 13 April 1945, his first day in the Oval Office, was to go forward with the United Nations program as planned. ${ }^{132}$ That choice was to continue with the scheduled San Francisco Conference intended to form the United Nations that ran from April through June of $1945 .{ }^{133}$ This decision was not surprising since in 1943 then-Senator Truman had gone on a crosscounty speaking tour promoting internationalism sponsored by the United Nations Association. ${ }^{134}$ Further, he believed that, “. . . it was what Roosevelt had wanted, and it had to take place if we were going to keep the peace."135 Truman also said in his memoirs, "I was trying to profit by the mistakes of Woodrow Wilson .... I hoped that we would come out of this war with a going world organization for peace ...."136 Repeatedly, President Truman told members of the State Department that the United Nations was "the cornerstone of U.S. foreign policy." ${ }^{137}$ Moreover, Truman's hope was 
that establishing the United Nations would make amends for the United States' failure to join the League of Nations in 1919. As with other initial foreign policy decisions Truman saw his role as continuing FDR's vision; a new world body led by the United States, that could produce a new world order. ${ }^{138}$ At the time there was also the tacit desire on the part of the American people for the United States to be able, through this new world body, to intervene between other powers like the Soviet Union and British Empire. ${ }^{139}$

As for the European empires in general, Truman was concerned about ongoing actions in the underdeveloped regions of the world as well as developing events. In his memoirs regarding his first year in the White House, he explained the situation,

Violent resistance movements were developing in North Africa, the Middle East, and the redeemed areas of Asia, all in the name of liberation. They sought immediate freedom from established colonial powers, who were, of course our allies in the main war. We, as a people, have always accepted and encouraged the undeniable right of a people to determine its own political destiny .... But the real problem, as I saw it in its application to immediate events, was not one of principle .... The real problem was that of procedure and method. Amid the shambles of a world breaking down, we were desperately in need of machinery not only to deal with international disputes but also to provide assistance and encouragement to peoples in their peaceful aspirations. I was thinking primarily of a world organized for peace and of our plans for the United Nations. ${ }^{140}$

In this telling statement, Truman not only expressed a desire to see the end of colonialism but also articulated the quandary facing the United States government. Administration officials, including Truman, were aware of the social forces of growing rebellion in the European colonies energized by the Second World War. While philosophically supporting the right to freedom for all peoples they feared the instability that could occur in a fragile world just coming out of a devastating world war. Additionally, national selfinterest by the United States, as well as others, encroached on Roosevelt's idealistic wartime hope that the United Nations would be strong enough to administer order. ${ }^{141}$ 
Truman's initial hope, at least according to his public words, was that the United Nations was the right tool to bring about the changes needed in the underdeveloped regions of the globe in a slow and orderly manner that would not sacrifice stability in the postwar world. In a 1948 speech, Truman boasted that the United Nations had succeeded in getting the British and French to withdraw from Syria and Lebanon, and the Dutch to secure a truce with the Indonesians, though he did not mention anything about the pressure the United States had exerted in these situations. ${ }^{142}$ In a 1950 report to Congress Truman stressed that the United Nations continued to be "Point I of our foreign policy." 143 In the same speech Truman emphasizes that the mechanism to provide "advancement of trust areas and other non-self-governing territories is steadily being fostered through the cooperation of administering states and the United Nations." 144 In his memoirs years after his Presidency, Truman continued to assert that the United Nations was the only appropriate mechanism for solving problems in territories overseen by the Europeans since they were the ones capable of addressing the transition from colony to independent state in a rational, systemic manner that would avoid chaos. Additionally, when he talked about the British-administered Palestine and the resulting birth of Israel he felt that the UN should have dealt more forcefully with the issue and claimed that the United States only became involved because of external pressures. ${ }^{145}$

Scholars can argue that the UN's policies during this time were simply an extension of the United States' due to its overwhelming power in the world. However, as seen in the next section the United States lacked a cohesive strategy to direct its national might at the problem of undeveloped areas still under colonial control. In addition, though the 
European empires were weaker they were not without influence in the new world body and they united to prevent any programs that were not in their national interest.

\section{TRUSTEESHIP SYSTEM}

In addition to the better-known bodies of the United Nations, the Security Council and the General Assembly, there was the Trusteeship Council. The Trusteeship Council evolved from the old League of Nations' Mandates Commission designed originally to control territory previously governed by nations defeated in World War One. FDR saw the transformation of the Mandates Commission into the Trusteeship Council as the answer to what he perceived as being the biggest world threat, Europe's system of imperial rule. The intent was for the council to manage the peaceful transition of European colonies to independent states. ${ }^{146}$ Under Roosevelt's direction, the State Department had worked on the concept as one of their major wartime initiatives and they continued to push for adoption in the postwar period. ${ }^{147}$ "By the spring of 1944, Department of State officials were ready ... They gave the UN a decisive role in controlling trust areas, with provisions for inspections and mandatory reports on conditions .... Roosevelt believed that the provisions for inspection and publicity would be a powerful inducement for more liberal colonial policies."148 The State Department also included independence as the chief goal for the system. However, as previously discussed, FDR was under considerable pressure to reduce the scope of the concept and delay any final decision until after the war. ${ }^{149}$ No one will ever know what Roosevelt's intent may have been when he yielded to the British at Yalta. Nonetheless, by agreeing 
to the delay, his sudden death put the trusteeship issue at Truman's feet to deal with as soon as he took office. The actual establishment of the Trusteeship Council during Truman's early administration would prove to be a glaring example of the President's rhetoric not matching his actions. The American delegation to the 1945 San Francisco Conference forming the United Nations allowed the European participants to change the wording of the plan from the clear word independence to the more ambiguous word selfrule and then left it to the discretion of the Europeans which of their colonies to include in the trusteeship program. ${ }^{150}$ The trusteeship was only official for mandates that had existed under League of Nations' agreements and recently captured enemy territories. In Truman's defense, considerable pressure existed to weaken the trusteeship's scope of operation. There was even fear that Churchill, and the British government, would be successful in having the whole trusteeship concept thrown out if the word independence remained in the language of the plan. ${ }^{151}$ Despite agreeing to the weakening of the plan, the State Department did take the lead in insisting on establishment of the trusteeship program during the San Francisco Conference. ${ }^{152}$ Truman's draft memoirs also indicate that he took a far more active role in this process than is implied in the finished version, which only specifies that Truman approved a series of instructions for the American delegates. ${ }^{153}$ The draft memoirs include statements such as this personally issued Truman directive, "On April 18 I issued a directive to the delegation on the American policy on trusteeship. I stated that at San Francisco it was not proposed to place any particular territory under a trusteeship system." ${ }^{154}$ Truman then pointed out that at the Yalta Conference it had been agreed that non-League of Nation and non-captured territories of the war would become part of the program with the approval of the ruling 
colonial power. ${ }^{155}$ Another example of Truman's hands-on approach to the issue of trusteeship, not found in the final version of the memoirs, includes "On April 27, I received a draft proposal on trusteeship prepared by the American delegation. This draft conformed to my general directive of April 18 on trusteeships. This was one of the key issues of the conference and I wanted it to be as clear as it could be in every detail of technical and legal phrasing." 156 Even weakened in scope the Trusteeship Council still provided a useful forum to help end colonialism by providing a sense of legitimacy to the cause of returning self-rule to local people. ${ }^{157}$ Further evidence of the eventual magnitude of the program came in a 1951 article that claimed at that time the program included 85 different geographical entities, covering almost nine million square miles, and a hundred and seventy million individuals in Asia, Africa, and the Caribbean. ${ }^{158}$

The trusteeship concept did have adversaries both in and out of the Truman administration. As discussed, Churchill had been an enemy of the trusteeship program since its conception and successfully fought at Yalta to remove the European colonies from inclusion. ${ }^{159}$ Nevertheless, the British had to fight the battle all over again during the formation of the UN. During this altercation, the French delegates collaborated with the British to resist the mandatory addition of their colonies and they received support in their efforts from the United States military. ${ }^{160}$

The American military wanted to retain control over Guam, Samoa ${ }^{161}$ and "Japanese islands seized during the war including the Marshalls, the Marianas, and the Carolina"162 island chains (See Figure 1) ${ }^{163}$. Controlling these geographic assets would give them complete control over the lines of communications in that part of the Pacific and the ability to control strategic access to a large part of the Asian continent. ${ }^{164}$ These bases 


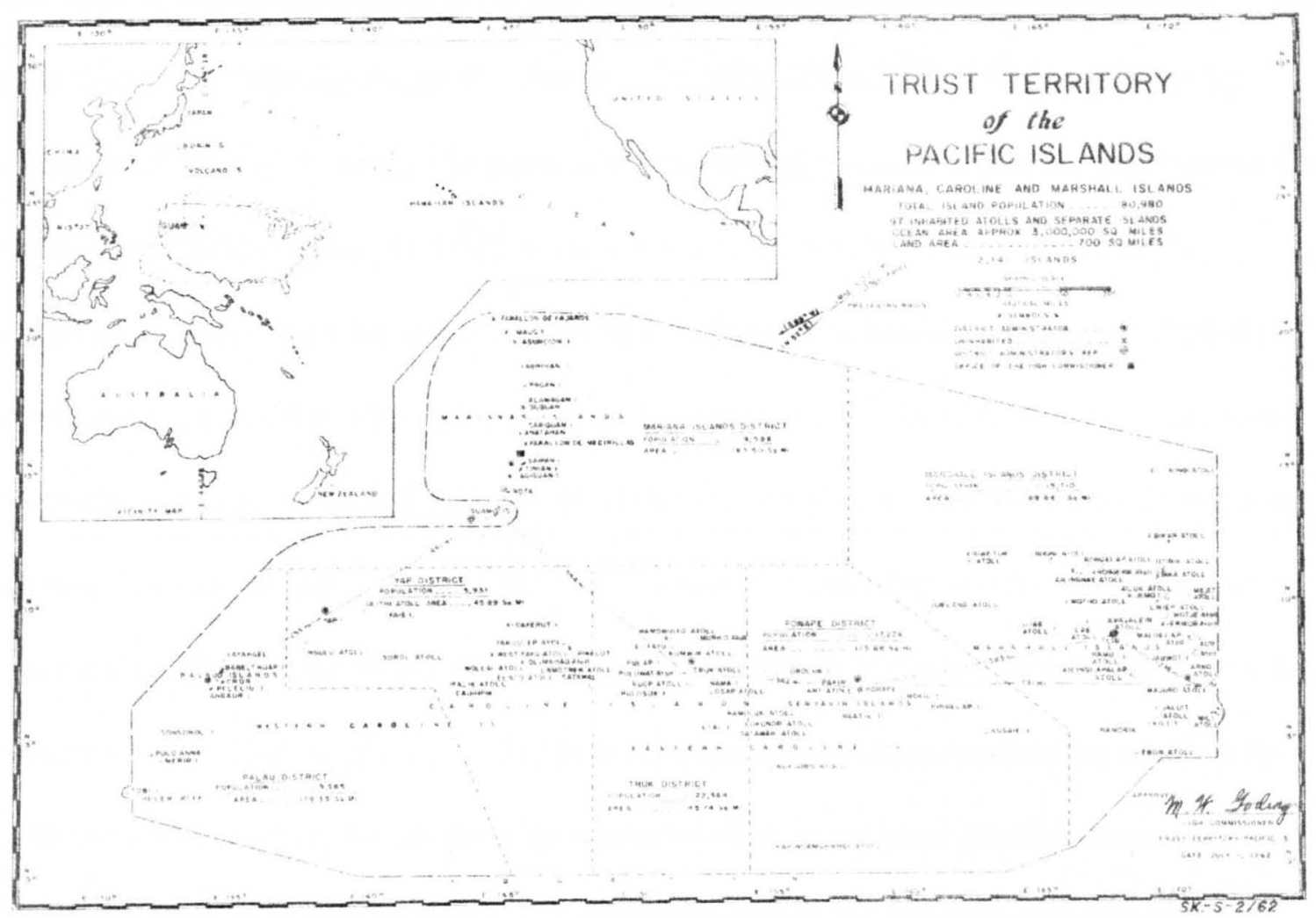

Figure 1

would also enable the United States to continue to project air and sea forces well beyond its continental boundary. ${ }^{165}$ Early on, Pentagon officials had argued against discussing the disposition of captured Pacific islands while the war was still ongoing and had convinced the Department of State to exclude them from the trusteeship talks at Dumbarton Oaks and later at the Yalta Conference. At the United Nations Conference to get around the all-or-nothing approach to inclusion of territories in the trusteeship program a compromise idea arose. Certain strategic areas within regions initially designated as trusteeships, such as certain islands in the Pacific, would now fall outside of the Trusteeship Council's direct influence. ${ }^{166}$ Some 1948 news conferences addressed Truman's public position on the subject of the islands when he said, "Those that we do 
not need will be placed under a U.N.O. [United Nations Organization] trusteeship." ${ }^{\$ 167}$ he said moreover, "that the national defense necessities of the United States will not be sacrificed." 168 The Truman administration did attempt to create a pathway to freedom for these island holdings and by 1948 devices such as the South Pacific Commission, established under the auspices of the United Nations' Trusteeship program, included the mission to prepare the islands for ultimate independence. ${ }^{169}$ In addition, the Trusteeship Council served as a public forum for colonial issues and was later successful in applying pressure on the British government. ${ }^{170}$ The issue of trusteeship is a fine example that Truman's policy on colonialism is a mixed bag. Truman at first supported the trusteeship concept but yielded to internal and external pressures and compromised his position in order to address other, higher priority concerns, such as national security issues.

Another of Truman's advisors, not discussed earlier, played a pivotal role in the American military's weakening of the trusteeship program. James Forrestal, Secretary of the Navy and the first United States Secretary of Defense, was the leading advocate to retain control of the Pacific islands until his departure from the Department of Defense and his sudden death in 1949. Forrestal's diaries lay out the Department of Defense's case for keeping the islands and describe the infighting within the administration. $\mathrm{He}$ chronicles the idea that the islands were not colonies but "rather 'defense posts' necessary to the big power responsible for the security of the area, and their disposition, along with that of other strategic frontiers and territorial acquisitions, should be settled by the big powers in advance instead of through the proposed trusteeship mechanism."171 The contention that the islands would not be colonies but only controlled by the United States because they were strategic defensive positions seems to be rather specious. The 
end result is still a foreign power controlling a country though the Department of Defense argued that the islands could not be considered colonies because the local population would be free from the exploitative economic and cultural arrangements that marked traditional colonies held by the European empires. ${ }^{172}$ The idea of using the islands as defense posts first circulated at the Dumbarton Oaks Conference and Forrestal's diaries provide depth to the administration's behind-the-scenes wrangling over the issue. A 21 January 1946 entry captured Forrestal's surprise upon finding out that Secretary of State Bymes, with Acheson's encouragement, had pushed Truman to announce that the Pacific islands would shortly become part of the Trusteeship program under the control of the United Nations. The State Department's thinking on the subject was that following the military's lead would result in "reservations of other territory by other nations until the non-aggrandizement plan of the Atlantic Charter would be a mockery...." ${ }^{173}$ An incensed Forrestal saw Truman that afternoon to counter Byrnes' attempt to change what he thought had been settled at the earlier San Francisco Conference. Forrestal also criticized Acheson's actions as being unprofessional according to the entry, which is sympathetic to Truman. ${ }^{174}$ In later entries, Forrestal talks about the need to keep the islands out of the trusteeship program and implies that the State Department is working to thwart him. ${ }^{175}$ From Forrestal's dairies it is clear that the issue of colonialism was not a static process and that Truman's advisors did not speak with one voice. Truman's memoirs reinforce this picture of infighting and conflicting objectives when he says, "In . .. meetings with Cabinet members on the question of trusteeships, I found that the State Department held views that differed from those of the War and Navy Departments .... In the end I sustained the Army and Navy chiefs on the major issue of security of the 
bases." 176 This exclusion of strategic areas from United Nations' control would translate to changes in the United States position on colonialism even though Truman would have preferred to do otherwise.

Even while agreeing with the military's stance about continued control of the Pacific islands Truman was of two minds. In a 6 November 1946 statement, Truman said, "The United States is prepared to place under trusteeship... Japanese Mandated Islands and any Japanese Islands for which it assumes responsibilities as result of the Second World War."177 Yet in the same statement, he talks about the strategic area concept for the islands and its presentation to the United Nations' Security Council. ${ }^{178}$ Nevertheless, after weighing the options Truman decided that retention of these islands was in the United States national interest. Regardless of the reasoning behind the decision, the exclusion of the islands from the United Nations' trusteeship mandate still troubled Truman years later when wrote his memoirs. He explained his feelings, "My attitude was always that while it was necessary for us to control certain islands in the Pacific until peace was established, these territories should not be closed to the rest of the world. I believed we should set up civil governments as soon as possible to replace the military governments. Some of the military objected, but while I remained President I intended to try to get as near to self-government as we could wherever we had the responsibility." The impression one gets is that Truman felt the duty to ensure national security but was uncomfortable holding onto the islands indefinitely therefore he attempted to rationalize his position by saying that he still supported the Pacific islanders' right to independence at the earliest feasible date.

One should note that the captured islands of the Pacific were not the only holdings of 
the United States. The future States of Hawaii and Alaska were still territories during Truman's administration but did not fit the definition applied to the European colonies. Though these territories did not become States until 1959, they were in the process of joining the Union. Truman noted in a 1950 public address, "One of the principal reasons why I am anxious to see the Territory of Hawaii and the territory of Alaska become States is because of their vital importance to the defense and to the welfare of the United States of America." 180 Truman was pushing independence for another territory even more rapidly, "The intention of President Roosevelt and the Congress to give early freedom to the Philippines ... was the will of the American people, and I was determined to carry it through to speedy fulfillment .... I hoped that by making the Philippines as free as we had made Cuba it would have an effect on British, Dutch, and French policy in their Far Eastern affairs." ${ }^{\prime 81}$ Others in the government also hoped that the European imperial powers would emulate the orderly and controlled decolonization of the Philippines as practiced by the United States. ${ }^{182}$ Independence for the Philippines came via Presidential proclamation in 1946 with the caveat that the United States could maintain twenty-three military bases on Filipino soil on a ninety-nine year lease. ${ }^{183}$ Truman boasted about the United States' actions in a speech about Puerto Rico's future, "It is our pride that this policy was faithfully pursued in the case of the Philippines. The people of the Philippines determined that they desired political independence, and the Government of the United States made provision to this effect."

Truman also supported the idea that the citizens of Puerto Rico should have the same right to choose their own destiny. In the just mentioned speech, Truman was trying to persuade Congress that "It is now time ... to ascertain from the people of Puerto Rico 
their wishes as to the ultimate status which they prefer, and .... Congress, to grant to them the kind of government which they desire." 185 At the time, various island groups advocated diverse options: the right to elect a governor, the ability to become a State in the Union, full independence, or designation of Dominion status much like Canada's position in the British Commonwealth. ${ }^{186}$ Truman's steady and sympathetic view of Puerto Ricans remained in spite of the infamous 1950 assassination attempt by Puerto Rican separatists. At a press conference after their failed effort Truman said, “. . the people of Puerto Rico should have the right to determine for themselves Puerto Rico's political relationships to the continental United States." 187 He did more for the island than any other President had to that point, naming the first native Puerto Rican to be Governor, extending Social Security privileges to the people and authorizing the 1951 referendum at which the people overwhelmingly voted to establish their own Constitution and proclaim the Commonwealth of Puerto Rico. ${ }^{188}$ Neither Roosevelt nor Truman considered placing these territories under United Nations Trusteeship Council control as they staunchly advocated for other's colonial territories. Perhaps the reason was that, at least according to their rhetoric, both Presidents believed they had a viable plan to permit the territorial populace decision-making power over their own destinies unlike the subjugation and exploitation demonstrated by the European empires. Truman also seemed intent on doing what he could while in office, if unable to confer their freedom he pushed for future autonomy.

The first years of the Truman administration were anti-colonial in both rhetoric and policy decisions. Truman saw the United Nations' trusteeship program, not United States foreign policy, as the legitimate means to make the anti-colonial program work. Some 
people may view this as Truman practicing a hands-off policy on the issue but his own words indicate that he saw this role as appropriate for the UN, a role that Wilson's League of Nations was fated never to have a chance to fulfill. In spite of major compromises regarding strategic areas, the core concept of the United Nation's trusteeship structure had the constant support of Truman. Moreover, Truman continued advocating self-determination for United States' territories, including Pacific islands, and supported their right to decide their own fate if in a rather unhurried and methodical way.

\section{COLD WAR / SHIFTING POLICIES}

As time passed and other foreign policy issues, such as the Cold War, presented themselves the issue of colonialism became more difficult for Truman and his administration. These new issues encompassed more than just the discussed points that focus on the conflict between the United States and the Soviet Union. The world was different than it had been before World War Two and, more importantly, had fundamentally changed from the world at war that FDR had understood. The situation was thus, “. . . within the past thirty-five years the world had gone through ... the passing of five empires and the drastic decline of two major imperial systems, the French and British. These events had altered the historical distribution of power until now there were only two major centers of power remaining, the United States and the Soviet Union."189 As the climatic events of the Second World War receded, it was natural for the United States to reassess its foreign policy. In the midst of this reassessment, the administration had to prioritize competing objectives to include the issue of colonialism and the 
European empires.

One of Truman's major policies related to colonialism was a break from FDR's policy ideal of reducing Europe's power and significance. The World War had degraded the international influence of Europe, reducing it to a level few at that juncture could comprehend, including the President of the United States. ${ }^{190}$ The European empires, were attempting to restore their colonial holdings around the globe even before the war ended. However, their efforts to resume control of their colonies in the postwar period were proving problematic and Truman, along with others in the American government, watched the Europeans with growing concern. The war had devastated home countries and reconstruction was essential, a point that troubled the Truman administration. Acheson spoke in an interview about the condition of postwar Europe and the United States' aid programs to Europe during the Truman administration, "It didn't really strike home to us that the British Empire was gone, the great power of France was gone, that Europe was made out of four or five countries of $50,000,000$ people. I still looked at the map and saw that red on the thing, and, by God, that was the British Empire, the French Senegalese troops in East Asia and in Germany--all of this was gone to hell. These were countries hardly much more important than Brazil in the world."191 The empires had not yet vanished but their power had dwindled, they were not the same empires that had started World War Two.

\section{WINTER 1947 / A WEAKENED BRITAIN AND EUROPE}

Both Europe and Great Britain were still near collapse two years after the end of the 
war. The war had virtually destroyed the British merchant fleet, and English companies had lost foreign capital investments. By 1947, one-half of the factories in Britain had shut down and the remaining factories had to close for up to three weeks during the winter due to a shortage of fuel. ${ }^{192}$ By this point, unemployment had jumped to fifteen and half percent ${ }^{193}$ and on the diplomatic front the British had begun informing the Truman administration that they were withdrawing from the world scene. ${ }^{194}$ A British economic white paper at the time described their financial problems as "extremely serious" and said the need to reduce troop strength rapidly was self-evident. ${ }^{195}$

The European continent was in even worse shape than Britain with productivity at one third of pre-war levels and infrastructure recovery at a snail's pace. ${ }^{196}$ The French economy had suffered under Nazi control and even with prodigious efforts at steel production; there still was only half of the amount needed to begin rebuilding. More importantly, most of France's meager finances bought food to supply the population rather than reconstruction and the other countries in Europe were in no better shape. ${ }^{197}$ Later the Marshall Plan would aid reconstruction on the Continent, but in 1947 even the United States recovery efforts were not complete and in the end, Britain received no economic support at all via the Marshall Plan.

The devastating winter of 1947 illuminated the dire condition of Europe, particularly Britain, to the American people. The winter was exceptionally severe and a late frost destroyed millions of acres of wheat and other critical food crops. ${ }^{198}$ Weather conditions were dreadful and brought countries to a virtual standstill. On 13 February 1947, Truman acknowledged the emergency and announced that he was sending fuel oil, coal and wheat shipments to the British Isles and Europe. ${ }^{199}$ In a later interview about the winter, he 
pointed out that Europe had not seen such a crisis since the Middle Ages. He described their plight, "People were starving, and they were cold because there wasn't enough coal, and tuberculosis was breaking out .... The British were broke...."200 At the time there was a feeling that Europe's problems were the epicenter of a huge crisis, " . . not only had the international system not been rebuilt-it seemed about to collapse entirely."201

The winter of 1947 served to drive home two points about Europe's circumstances. First, that Britain, by far the largest colonial power, was not going to regain the international might it had enjoyed at the height of the British Empire. Second, that France and the other nations of Europe, even with help from the United States, would not recover any time soon. These realizations would affect American foreign policy in broad terms. From the aspect of imperialism, the Truman administration had to readjust their thinking and view the European empires, including Great Britain, not as being in a position of strength but rather in a state of weakness that threatened world order. The danger of European empires drawing the rest of the world into their conflicts had vanished. The continuing plight of a weakened Europe, highlighted by the winter of 1947, was the catalyst that produced competing objectives for American foreign policy, the need to stabilize and rebuild Europe versus ending European colonialism. These competing aims were further heighten by Truman's Euro-centrists foreign policy advisors. Another factor that played a role in Truman's evolving decision-making process was the status of the colonies themselves where the war and postwar circumstances destroyed the old European-controlled social order thereby opening the way for nationalist movements. These movements increased the instability of the regions since they sought immediate self-rule and independence. 


\section{EUROPEAN COLONIES}

In addition to the Truman administration's concerns with the problems of Europe, events in current and former colonial holdings also demanded their attention. The newly created Central Intelligence Agency (CIA) undertook a series of assessments regarding the underdeveloped areas of the world to address this need. Truman's personal copies of CIA reports compose the material examined in this section. A general impression garnered from the reports was that the disintegration of the empires had left former colonies unprepared for independence or in open conflict with European attempts to reassert control. Another general aspect that the reports dealt with was the issue of access by the United States' to the resources found in those colonies and former colonies. The reports are broken down into the major European colonies, first the British, and then French and Dutch Empires and they cover some of the major underdeveloped regions in the Middle East, Asia and Africa.

First, a look at the big picture and the general condition of the European empires' grasp on colonies around the world as described in the intelligence reports. The CIA's 1948 assessment of European colonialism was that its demise was inevitable. Overall, colonies around the globe had increased their efforts to secure freedom since the end of the Second World War. Some reasons for the increased nationalism included Japan's success during the war in driving European imperialists from the Pacific region, the postwar weakness of the Colonial powers, internal socialist movements, general support for colonial freedom by other nations including the Soviet Union, and the creation of the 
United Nations as a means and forum for the liquation of colonial rule. Furthermore, every effort by the Europeans to reassure the colonial populations had failed and it was unlikely that the breakup would be a controlled and orderly process. The instability in these colonies and former colonies was spreading to the rest of the world and perceived as a direct threat to American national security. The threat to security was comprised of three elements; the loss of military bases, the further weakening of already exhausted European allies, and the loss of strategic materials needed by America's economic sector and military. The last factor was especially troubling because many strategic materials were exclusive to the colonial regions. ${ }^{202}$ Additionally, the United States' overall foreign policy endeavors were at a disadvantage because conflicts between the Europeans and colonial populations had tainted local attitudes toward any western nation, including the United States. CIA reports in 1951 and 1952 also raised the specter of communism's growth, especially in South Asia. As for the Near East, the European powers were trying to retain their influence that caused problems for American efforts. The CIA was more dismissive of the threat of communism in the Near East than the Far East. ${ }^{203}$

The majority of the CIA reports dealt with the biggest and most powerful of the European empires. The overall assessments of the British focused not on how to end the British Empire but on the affects, its ultimate decline would have on the international scene. The CIA's opinion was that without its colonies Great British lacked the natural resources to maintain a position as the number three world power or even a second tier power. ${ }^{204}$ Additionally, they asserted that Britain's problems were economic and grew out of a growing loss of industry in the British Isles. ${ }^{205}$ Furthermore, the ties that bound the Commonwealth countries to Britain were weakening and the British no longer 
exercised their past influence on these former colonies. ${ }^{206}$ The agency also noted that there were fundamental differences in administrating the colonies between the British Empire and other colonial powers, especially the French. The report says, "In contrast to French colonial theory, which makes representation in the parliament of the metropolitan country the goal of colonial political development, the British in general offer their colonial peoples a gradual process up the ladder of increasing self-government with Dominion Status [sovereign Nation within the British Empire] at the top ...."207 The overall tone of the CIA reports is sympathetic to Britain, an ally in decline.

Individual reports about various portions and colonies of the British Empire focused on their possible impact on American foreign policies. For example, the CIA points out that the newly independent state of India was pursuing a course of neutrality in the United States/USSR conflict. Additionally, the new nation was redirecting its anger over British colonialism towards the United States. ${ }^{208}$ In the Near East, residual anger of the people towards Britain and France had led to general anti-Western feeling making American efforts problematic at best. ${ }^{209}$ In 1948, the CIA held that in spite of problems with the British presence in Malaya it nevertheless ensured American access to the area's rubber, tin and strategic ports. CIA analysts also predicted that within the next five years the British would grant Malaya more independence. ${ }^{210}$ Finally, a 1950 report on the British colonies of West Africa focuses on strategic materials such as columbite and manganese. This report is dismissive of local efforts to attain autonomy citing the apathy of a large portion of the population. The report said that this apathy, combined with efforts by the British to increase the tempo of granting of self-government, would preclude any serious problems in the region. ${ }^{211}$ As with the general reports concerning 
Great Britain, the specific CIA reports about the colonies or regions are positive in their treatment of the British government while focusing on the American perspective.

The CIA also analyzed France and its colonial holdings in the postwar period. First was a 1947 report on the general state of France in which the CIA revealed that the French government was attempting to recover international stature lost during World War Two. The study said that French leaders considered reestablishment of the French Empire the key to regaining the prestige of the worldwide community. ${ }^{212}$ The report stressed this point by saying, "France views its colonies as indispensable to its prestige." 213 The report also pointed out that France was of great strategic importance to the United States even though currently in a weakened state as a leader in Western Europe. ${ }^{214}$ A 1950 report on France noted that despite their declared aim of establishing a more tolerant policy toward colonies that, "The reforms promised but not implemented by the French are being countered by far-reaching native nationalist demands for greater freedom, extending in some instances to complete independence and autonomy."215 The overall view of the French situation is much more negative than the coverage found in CLA reports on the British Empire.

As for French colonies, a series of CIA reports paints a pessimistic picture of their future as well as the efforts of the French government. In Tunisia, nationalists were increasingly asserting themselves in the affairs of the country and in opposition to the French. ${ }^{216}$ Another description of the rest of Northern Africa said, "While there is no immediate danger of a successful revolt in French North Africa, increasing nationalist intransigence and continuing French failure to institute a sincere program of reforms may turn what is now a political problem into a situation dangerous to peace and to the 
security of the US."217 On the other side of the world, the picture was even gloomier for the French Empire. A northern Vietnam Communist movement, with ties to the Chinese Communists, was threatening the French presence in Indochina, Vietnam, Cambodia, and Laos. The CIA concluded that unless the French appreciably increased the number of military forces in the area they would lose control of the region and most assuredly Vietnam. The Communists of the Viet Minh movement, augmented by Chinese troops and successfully exploiting popular nationalist feelings, were proving more than a match for colonial forces. The report continued that given the current situation it was unlikely that France would even be able to maintain their strength long enough to establish an autonomous Vietnamese government around which the anti-Communist elements could rally. ${ }^{218}$ A CIA estimate during the last year of Truman's Presidency forecasted “. . . the French will continue their war effort in Indochina. ... However, while insisting upon the protection of French interests, the French will attempt to limit their commitments in Indochina by demanding additional US financial assistance and by seeking commitments for US-UK military support in the defense of Indochina."219 The same report predicted that the Chinese would not directly intervene in the conflict but would continue to increase aid to Viet Minh. ${ }^{220}$ The CIA reports found in Truman's files were collectively negative about France's ability to direct a peaceful and systematic transition to autonomy for their colonies, unlike their overall assessment for the British controlled territories.

The awareness of the CIA reports kept Truman focused primarily on Britain and France's colonial problems and therefore the other colonial European powers received scant mention. The CIA analyzed the holdings of Belgian, Spain and Portugal in central and southern Africa but not to the degree that Britain and France were covered. For 
example, a report assessing Portugal was blunt when it said the country and its colonial holdings, with the exception of airfields in the Azores, could do little militarily or economically for the United States. ${ }^{221}$ Only the Dutch colonies in Indonesia warranted any degree of in-depth scrutiny when compared to the French and British assessments. The United States' strategic interests in the area, according to the CIA reports, was because Indonesia had large oil reserves and provided the majority of the world's supplies of tin, rubber, and quinine. ${ }^{222}$ Furthermore, the Dutch had launched some illadvised and ill-fated military operations in the region in an attempt to quell the insurrection and reestablish their power. The ramifications from Dutch actions caused strategic problems for both the United States and the United Nations. ${ }^{223}$ The tone in the CIA report, "Consequences of Dutch 'Police Action' in Indonesia"224 is akin to the dismal predictions about French colonial efforts. Another point made in both the French and Dutch reports was the alarming growth of communism in the underdeveloped regions of the world and the consequences this expansion could have upon American foreign policy objectives. $^{225}$

\section{BIPOLAR WORLD}

An examination of the period, and Truman's Presidency, would be incomplete without a look at the Cold War aspects of the colonial question. The description of this timeframe is one of “. . . opposing trends ... development of a bipolar world, and continued breakup of old European empires. ${ }^{226}$ The frequency with which the subject of communism came up in Truman's 1951 speeches and press conferences indicated that the 
issue dominated his foreign policy agenda in his later Presidency. ${ }^{227}$ In a 1948 press conference, when asked about world communism, Truman went so far as to say that the single source of the world's postwar volatility, "... lies largely in the attitude of one nation-the Soviet Union." ${ }^{228}$ As Truman and his administration were abandoning hope for cooperation with the Soviet Union and advancing towards a full-blown Cold War the question of colonialism, and the United States' approach towards it altered. As the European empires lost influence in their colonial regions, the focus shifted to the power vacuums created in Asia, Africa and the Middle East. The problem of Communist influence at first seemed minor but when they successfully exploited the chaos caused by precipitous withdrawal of European colonial rule the Truman administration's concerns soon grew to eclipse other considerations. ${ }^{229}$ Some argue that, especially in Africa:

In the decades after World War II ... the United States refused to press for independence and the end of colonialism. The government attempted to follow what it considered a middle course, assuring colonial peoples of American sympathy and good will while supporting or acquiescing in the continuation of European control.... While the search for security pushed anti-colonialism into the distant background in the early years of the Truman administration .....230

The late 1940s saw public outcry from some of the Black Leadership, centered in the National Association for the Advancement of Colored People, claiming that the government was not aggressively pursuing the end of colonialism. However, their complaint did not garner much public support since Cold War rhetoric was intensifying across the nation. ${ }^{231}$ The Senate Foreign Relations Committee's Chief of Staff at the time perceived the problems Congress had charting a course through conflicting foreign policy objectives:

We were pushed hard by the colonial powers to support their position in the United Nations and not to encourage the independence of the developing areas too soon. And we were pushed hard by others who wanted independence for all of the 
colonies and the trust territories as rapidly as possible. The United States tried to be reasonable -- to chart a middle course. We recognized that if the colonies got their independence too soon this would put them in a difficult position because they wouldn't be able to maintain their economies, they wouldn't have the experience and the education and training for their people to survive as new states, at least not to make the kind of progress that we had hoped. ${ }^{232}$

In the State Department fear of uncontrolled change led many to realize that "They were not ready to see the colonial powers give up their colonies as quickly as they ... have."233 Truman rationalized his growing resistance to nationalism by noting that in some cases it led to negative consequences under Communist-inspired "extreme nationalism."234

The issue of colonialism also turned into a Cold War propaganda tool. The administration grew concerned that the Communists, the Russians in particular, were attempting to sway the popular opinion in colonial regions against the United States. The former Prime Minister of Greece said, “... the colonial powers did not consider advisable immediately after the war, to admit even to a certain degree that colonialism could any longer survive. They thus opened the way for Communists to make the best of what Lenin had already marked out: that is, for the Russians to become the champions of the peoples' right for self-determination and the pioneers of the abolishment of colonialism. ${ }^{.235}$ The second part of the Russian message was that the Americans were de facto imperialists because of the United States alliances with the European powers. A letter from Secretary of State Acheson to Truman about Russian politics playing out in the UN General Assembly said, "They have lumped the British and The French together with us as the Atlantic warmongers, and have made strenuous appeals ... to the ArabAsian bloc." 236 The Soviet's hijacking of the anti-colonialism message served to weaken European power while building Russian goodwill with the people of the colonial regions. ${ }^{237}$ The Soviet anti-colonial message also helped shift the Truman 
administration's efforts to focus on defeating perceived Communist-sponsored nationalist movements such as Ho Chi Minh's in Vietnam. While United States' foreign policy simultaneously supported nationalist movements such as in Indonesia that the administration portrayed as democratically inspired. ${ }^{238}$

Cold War rhetoric also changed the meaning of colonialism and imperialism with Truman's public attacks on communism referring to it as Communist imperialism. ${ }^{239}$ Truman described communism as having assumed the mantel of the imperialist with all the evils inherent to the role. While speaking publicly of the Soviet Union he said, "That imperialism seeks to gain its ends by intimidation, by fomenting disorder, and by attempts to force internal collapse., ${ }^{240}$ One of Truman's speeches talked about the Russians having imperial aspirations,

In the Far East, Communist imperialism presents us with another threat. There we see many new nations emerging, as our own countries once did, from colonial status to full independence .... But Communist imperialism has fallen upon these new nations with its weapons of internal subversion and external attack. It seeks to overpower them before they are strong enough to stand alone. ${ }^{241}$

In yet another speech Truman spoke of Russia as creating a new brand of colonialism, "It embarked on a new colonialism--Soviet style. This new colonialism has already brought under its complete control and exploitation many countries which used to be free countries."242 The 1950 capstone document of the Truman administration's fight against communism, NSC-68, also defined the Soviet Union's actions in negative terms as "Russian Imperialism." 243 With all the Cold War rhetoric, the American people's stance about colonialism altered. The British Ambassador to the United States at the time said, "Anti-colonialism in the United States today is a traditional attitude rather than an active crusading force ... the broad masses of the American people, including the liberals, are 
convinced that the supreme danger confronting their civilization is not old-fashioned colonialism but modern communism."244

\section{LATER TRUMAN POLICIES}

Even in the midst of the all-encompassing Cold War, there were several foreign policy programs directed at the problems of European colonialism or as Truman called it "The old Imperialism." ${ }^{245}$ At the end of his tenure, Truman spoke with pride about his administration's anti-colonial stance, "In the far East we have helped to create and strengthen a ring of new and independent nations from India to Japan. We have helped 600 million people to make their way from colonial subjection or dependency to independent self-government. ${ }^{246}$ Truman's response to the international problems of the latter 1940s was development of the Truman Doctrine and the Marshall Plan. Moreover, he launched the Point IV Program for regions of the world that had formerly been European colonies. ${ }^{247}$ Professor Robertson's book calls the Point IV Program "an acknowledgement that the nineteenth-century era of empire was over, a recognition of desire of independence for new states and of the social revolutions within them as people began to ask ... for something more than subsistence and subservience" ${ }^{\text {248 }}$

The Point IV Program was first unveiled in Truman's 1949 inaugural address. This program was the fourth point offered as part of a series of foreign policy initiatives to provide support to the undeveloped and colonial regions of the world. ${ }^{249}$ Truman described the Point IV Program as a way to "share our store of know-how and capital to help these people develop their economies and reshape their societies. ${ }^{, 250}$ He went even 
further to say that, the Point IV Program had "nothing in common with either the old imperialism of the last century or the new imperialism of the Communists. ${ }^{.251}$ In addition to serving as an altruistic alternative to imperialism, the program had other benefits. Truman personally described the Point IV Program as a way to counter "Communist propaganda"252 and increase the underdeveloped countries' ability to "produce strategic materials which are essential to the defense and economic health of the free world." 253 By the last year of Truman's Presidency, he boasted of the success of the Point IV Program with "technical and economic missions in 40 countries." 254 Indeed, the program spent millions of dollars during Truman's Presidency and ultimately evolved into additional aid programs. ${ }^{255}$ The underlying objectives of the Point IV missions, in Truman's words, were to “...encourage stabilized governments in underdeveloped countries in Africa, South America, and Asia, we could encourage the use of the development of those areas some of the capital which accumulated in the United States." "256 In his memoirs, Truman would say that the positive effect from the capital and technical support of the Point IV Program would be similar to the European empires' investment in early America without the colonial baggage. ${ }^{257}$ Regardless of the reasoning behind the program, Truman felt that:

Point Four was aimed at enabling millions of people in underdeveloped areas $\mathrm{t}$ raise themselves from the level of colonialism to self support and ultimate prosperity. All of the reports which I had received from such areas of the world indicated that a great many people were still living in an age almost a thousand years behind the times. In many places this was the result of long exploitation for the benefit of foreign countries, of developments for foreign benefit rather than for the interest of native peoples. This was the curse of colonialism, and I, for one, have always hoped to see it disappear. ${ }^{258}$

The Point Four Program was the centerpiece of Truman's self-described anti-colonial foreign policy in the latter period of his Presidency. The Point IV Program was also 
evidence that Truman did not forsake Roosevelt's legacy of anti-colonialism. Rather, Truman and his administration amended the policy to address current events and the changing foreign policy priorities of the new Cold War era. The effectiveness of the Point IV Program was debatable ${ }^{259}$ but at least its rhetoric was against both the old European colonialism and the new Communist imperialism.

\section{INDIVIDUAL EUROPEAN EMPIRES}

In addition to a general foreign policy program dealing with native aspirations around the world, Truman's foreign policy also responded to individual problems arising from the various European colonies and territorial holdings. This section looks at three major European empires and the Truman administration's response to each of the countries' colonial policies. The three major powers, Great Britain, the Netherlands, and France, each had sizable colonial holdings and each dealt with colonial crises during the latter part of the Truman administration. The United States' decision in each crisis provides insight not only into the administration's thinking but also offers some suggestions as to Truman's feelings on the subject.

\section{Great Britain}

The first nation examined is Great Britain, by far the largest and most powerful empire. As noted, Britain was the United States' closest ally and had the distinction of 
going through political upheaval and changing political parties in the postwar period. Gone were the Conservative Party and its leader Churchill, the great defender of the British Empire. Replacing him was Clement R. Attlee and his Labour Party.

The Labour Party assumed power before the end of the Potsdam Conference in 1945 and set about to change the empire. ${ }^{260}$ Their objective was to transform the British Empire into a Commonwealth and do away with colonial rule in a number of territories. ${ }^{261}$ Besides the professed benevolent aspects of this program by the Labor Party, this effort was really a practical attempt by a British government with limited resources to preserve the nation's international standing by leading a modern Commonwealth instead of an archaic empire. ${ }^{262}$

Early in 1946, the Labour Party-led government announced that in 1947 it would grant independence to India, their most important colony, thus beginning the nation's first major postwar wave of decolonialization. ${ }^{263}$ Moreover, by 1948, Burma and Ceylon achieved statehood. During this same period, the British were engaged in military operations in Malaya ${ }^{264}$ but by the early 1950 s, the Malayan troubles had been resolved to the point that successful talks for independence began. ${ }^{265}$ Britain also announced plans to reduce their presence in the Middle East and they removed various military forces from Syria and Egypt along with a complete withdrawal from Jordan and Palestine (Israel). ${ }^{266}$ Finally, on Christmas Eve 1951 Libya gained its independence. ${ }^{267}$ By the time Churchill returned to the role of Prime Minister in late 1951, the breakup of the British Empire was irreversible though he did try to slow the process while in office. ${ }^{268}$ The Labour Party's efforts to transform the British Empire left little for the Truman administration to do regarding ending British colonialism. Churchill, self-described 
defender of the British Empire and bane to Roosevelt's anti-colonial efforts, was temporarily out of power. For the next few years, Churchill would operate as the opposition party leader focusing on domestic politics and select initiatives such as his Iron Curtain Speech in Fulton Missouri where he tried to raise international concerns about the growing Communist threat from Russia. ${ }^{269}$ Nevertheless, while Truman and his administration were publicly supportive of Attlee's efforts to convert the British Empire $^{270}$ at the same time the Department of State continued to push Britain to comply with their 1945 agreement to open British colonial markets to American businesses and end the imperialist trade bloc. ${ }^{271}$ A British diplomat of the period said that the American State Department was single-minded regarding the liberalization of trade. ${ }^{272}$ Similarly, the administration kept up the pressure to open markets in the British-dominated Middle East. ${ }^{273}$ During a series of riots in 1949 , the State Department applied diplomatic pressure to accelerate independence for Libya, and the British came to believe that the Americans were trying to use Libya to spark independence movements in the region. ${ }^{274}$ The Truman administration tried unsuccessfully to convince Britain to negotiate an orderly transfer of power with Egyptian nationalists while still maintaining a lasting military presence, in the form of basing for aircraft and naval access, in the region. ${ }^{275}$

The decline of the British Empire and associated withdrawal of forces from Greece precipitated Truman's development of the Truman Doctrine that called for the United States to fill the growing power vacuum while combating communism. ${ }^{276}$ British withdrawal from other regions ultimately also played a role in Truman's decision to exert the power of the United States. Yet, Truman did not mean for this change to establish the United States as a replacement who would continue European colonialism. Rather, he 
intended to use this new approach as a means to pursue his well-documented antiCommunist agenda. ${ }^{277}$

\section{Netherlands}

The Netherlands provided a different story from the British efforts to divest themselves of colonial rule. The Dutch had experienced brutal treatment under the Nazi's, the countryside was devastated and during the course of the war they had lost control of their colonies to Imperial Japan. ${ }^{278}$ Dutch recovery efforts included restoring their dominion over Indonesia colonies after the British had secured the region. ${ }^{279} \mathrm{By}$ 1947, their efforts had turned into open warfare with the natives and in 1949 the Dutch colonial administration finally admitted defeat and withdrew from the region. ${ }^{280}$

In this case, the United States put significant pressure on the Dutch government to end its military efforts to reestablish control. ${ }^{281}$ This diplomatic pressure by the United States occurred despite the powerful European-first bloc in the State Department that initially tried to thwart American diplomatic efforts to end Dutch colonial rule. The motivation behind supporting the Dutch in regaining imperial power included the desire to help the Netherlands recover from the war and a belief that the Dutch could better extract important raw materials from the region. ${ }^{282}$ In this case, one of Truman's closest advisors, then Secretary of State Marshall, was the person who overruled the Department's Euro-centrists who saw the Netherlands as a client state. ${ }^{283}$ A senior State Department official at the time remembered Marshall's guidance, "he felt that we had to live up to the policies of the U.N. Charter with respect to Indonesia, and to affirm -- call 
it anti-colonial, perhaps it was -- the need for the independence of Indonesia."284 American policy towards Indonesia had originally been one of encouraging both sides to compromise but the United States became overtly anti-colonial when the Dutch failed to agree to reasonable demands of the Indonesian nationalists. ${ }^{285}$

In late 1949, Truman publicly granted the newly formed United States of Indonesia one hundred million dollars of Point IV Program funds to aid the country in its transition to self-government. ${ }^{286}$ The fact that American intelligence agencies deemed the nationalist movement in Indonesia to be free of Communist influences made support by the Truman administration and the American public that much easier. ${ }^{287}$ This situation is also a good example of some of the unintended consequences that can occur in foreign policy. As American and international public opinion swung to support the Indonesian nationalists the United States government pressured the Dutch to accede to the nationalists demands. This pressure was partly due to the government reflecting the will of the people but the fact that the belligerent Dutch military was dressed and equipped with American Lend-Lease supplies also embarrassed the administration. ${ }^{288}$ In this particular case, Truman and his administration put an anti-colonial policy into action that helped to secure Indonesia's independence. ${ }^{289}$

\section{France}

France had suffered as much or more than the Netherlands and fared worse than many other parts of a dysfunctional Europe. The country endured German subjugation and the fighting had devastated a large part of its countryside. Additionally, like the Dutch, the 
French had lost colonies to the Axis Power's conquests. Despite hopes for a quick recovery, dire problems confronted the French people for many years after the war. In the extended postwar period, the French were trying to simultaneously reestablish a national government, create some kind of viable economy that would provide subsistence to the population, and regain their former standing as a world power. Central to their national goals was the restoration of the old French Empire in Africa and Asia and at the center of the French imperial efforts during the Truman administration were the colonies in Indochina. ${ }^{290}$ Shortly after the end of the war, French administrators and soldiers began to filter back into the colonies while Allied forces looked on. At the same time, many in Washington hoped the situation would somehow resolve itself without direct United States inference. ${ }^{291}$

The greatest argument that Truman had pro-colonial tendencies was the United States policy concerning French colonial efforts in Indochina. ${ }^{292}$ During the first years of the postwar period, the Truman administration's response to France's return to Indochina was mute. Part of the reason was a continuation by the Truman administration of Roosevelt's policy of putting off the problem of Indochina independence until a more auspicious time. Another facet was that the United States lacked direct military involvement in the region. At the end of the war, the British military controlled the Theater of Operations where Indochina was located and other postwar issues occupied the Truman administration's attention more fully. ${ }^{293}$ Moreover, there was a fear within the United States government that if the United States pressed for immediate independence for the colonies in Indochina that the domestic politics within France might veer even more towards the Communist Party, which had already become the largest 
party in France by $1946 .{ }^{294}$ The Truman administration's position on the issue was a middle-of-the road approach; they would not interfere with the French's return but would pressure France to establish a firm plan for the region's independence. ${ }^{295}$ As noted in the earlier dispatches from Ambassador Hurley, there was concern about colonial forces using issued Lend-Lease equipment. Yet, American military supplies were ubiquitous among the Allies so it would have been difficult for the United States to preclude their use from occurring. ${ }^{296}$ Nevertheless, the United States' official policy was that French colonial forces would receive no assistance. For example, there was a ban on "American flag vessels to carry troops or war material to Vietnam."297

As the Cold War intensified in the late 1940s, the administration's decision not to pursue the divisive issue of Indochina independence received reinforcement since they were trying to secure French and British support for an anti-Soviet European coalition. ${ }^{298}$ Once again, Truman's position was in some ways similar to FDR's attitude when he chose alliance unity over the thorny Indochina problem. Additionally Truman, and others in the administration, perceived Indochina as a place where the French had been fighting, not nationalists, but rather "Communist Rebels" since the Allied occupation ended and the French returned to power in $1946 .{ }^{299}$ This anti-Communist vision no doubt prevented any positive response to the Soviet-tainted Ho Chi Minh's requests for aid, unlike the later United States' response to the nationalists in the Dutch colonies. ${ }^{300}$ According to Truman's memoirs, he feared a vast Soviet-sponsored scheme to seize control of all of Asia. He said, "After Korea, it would be Indo-China, then Hong Kong, then Malaya."301 While opposing Communist-inspired nationalists, Truman and his administration never advocated that the French colonial rule should continue in perpetuity. The 
permanent solution envisioned was to end colonial rule and replace it with a nationalist government favorable to the United States. Acheson described the administration's policy "As we saw our role in Southeast Asia, it was to help toward solving the colonialnationalist conflict in a way that would satisfy nationalist aims and minimize the strain on our Western European allies." ${ }^{302}$ Acheson would later couple greater issues, obtaining French support for the North Atlantic Treaty Organization and efforts to restore German military might, in exchange for United States support in Indochina. ${ }^{303}$ Nevertheless, by 1950 the administration's idea of minimizing the strain on France would include direct American support to French forces in Indochina against an alleged Soviet-sponsored insurgency. ${ }^{304}$ This support, more than any thing else, has tied Truman to French colonialism. Yet, nothing indicates that this support intended to reestablish a permanent French Empire in the region but rather served to oppose Communist imperialism ${ }^{305}$ and secure stability. Acheson said that United States intentions for the French “...meant a much more rapid transfer of responsibility and authority to indigenous institutions than the French had in mind and.... Although these types of talks went on for three years, they had no effect and the drain on France continued until the effort failed in 1954."306

Reinforcing this view of a more active role for America in Indochina's stability was a 1950 report generated by the State and Defense Departments that raised the issue of the economies and political stability of the Indochina and Indonesia regions. This joint report pointed out that for the area to recover from the war it needed stability and economic growth for the region's emerging nations rather than the closed markets found in Communist-dominated regions. ${ }^{307}$ This need for open markets was especially true for Japan, which lacked the raw materials required to restore their economy. 
The combined issues of communism, stability in the colonial regions, and the interests of allies no doubt drove Truman and his administration from a position of noninterference to a more active roll in ensuring the security of the colonies in Indochina. Moreover hindsight, as revealed by countless books and articles about the Vietnam War, has shown that Truman and his people failed to resolve the issue of Indochinese independence by convincing the French to be willing partners in real reform. ${ }^{308}$ For instance in 1949, the French promised to grant future independence to Vietnam, but only because they bowed to United States pressure. ${ }^{309}$ When working with France the Truman administration sought a nationalist solution to the Indochina problem rather than settling for a continuation of imperial power. The preferred solution was "... France to fight the anti-communist war and win ... and ... when battlefield victory was assured to magnanimously withdraw from Indochina." 310 The administration even viewed the "Bao Dai Solution" as a better alternative in Vietnam than colonial rule. ${ }^{311}$ This Frenchinspired solution convinced an ineffectual Emperor Bao Dai to return to Vietnam in 1949 to serve as Head of State to a new government in South Vietnam. ${ }^{312}$ This change in Vietnam's colonial status was in no small measure a response by the French to the Truman administration's renewed pressure to resolve the nationalist problems. ${ }^{313}$ The grant of United States aid in the form of supplies, money, and personnel to Indochina in 1950 immediately followed the French ratification of Vietnam's independence and Truman's recognition of the Bao Dai government. ${ }^{314}$ Until China fell to the Communists, along with other setbacks in 1949 , the Truman administration had been reluctant to agree to the Bao Dai Solution. However, the official endorsement of NSC-68's more militant containment policy, an ongoing Korean War and tougher anti-communism rhetoric 
throughout the government in 1950 overrode earlier anti-colonial considerations.

Therefore, Truman and his aides felt that they had little choice other than to support the Boa Dai government. ${ }^{315}$ Still, the ill-advised recognition of Bao Dai and the grant of aid in 1950 were more representative of the Cold War policy to contain communism than a sign of Truman's latent approval of colonialism..$^{316}$ 


\section{CHAPTER V}

\section{CONCLUSION}

Harry Truman is a subject well worth studying since he was in a unique position to establish the underpinnings of a national containment policy that lasted throughout the decades-long conflict with the USSR. Moreover, he was the first to handle the diverse facets of that late twentieth century global contest which included a massive arms race, proliferation of defensive alliances, proxy wars, economic warfare, and propaganda wars. As a result, historians have made a thorough and detailed study of Truman's response to the challenges in the period after the Second World War.

The following conclusion is similar to the blending of ideas found in the Postrevisionism school, in that it supports elements from the two earlier schools of thought regarding Cold War history, the Traditional and the Revisionist. First, bolstering the traditional view is the fact that Truman espoused the ideals of independence and self-rule for colonies and pushed for those goals where possible, whereas the Communists practiced a different type of subjugation of native peoples. On the other hand, the revisionists appear correct in contending that national security goals ultimately won out over universalism. Roosevelt and Truman's ideology advocated the end of colonialism but concerns about maintaining the military alliance in World War Two, and containing communism during the Cold War, impeded the advancement of independence for the 
European colonies.

Another subject of interest, though not studied as extensively as the Cold War, was Truman's management of the repercussions caused by the decaying European empires. The analysis included Truman's private correspondence, public rhetoric and actual policies employed when dealing with the Europeans. Specifically, the paper studied Truman's attempts to either advance or undermine the European empires' colonial control. A different feature of the inquiry was the attempt to determine the consistency of the administration's foreign policy on the issue of Europe's external colonies. The last aspect considered was the connection between Truman's personal beliefs about colonialism and his administration's conduct of foreign affairs. These were the main issues examined and the search for their answers required scrutinizing many different areas of research.

The methodology used to study Truman must position him within the greater context of his times. The analysis must consider the ongoing war activities at the time of his elevation to President, the existing state of the European empires, the anti-colonial legacy of Roosevelt and the changes occurring in the postwar world. While examining these factors in an attempt to obtain a clear sense of Truman's point of view concerning the world in general, and colonialism in particular, it became obvious that the study needed to include Truman's closest foreign policy advisors. The ultimate determination of this research and analysis is that Truman was in fact opposed to colonial rule in both word and deed though events later in his Presidency caused his administration to implement policies that contained a pro-colonial flavor.

The following summation of supporting observations will help amplify the thesis 
about Truman's animosity to the institution of colonialism and the idea of imperialism. First, despite the large volume of information about FDR's position of profound condemnation for colonialism questions still exist about what his future intentions were in light of his equivocation on the return of France to Indochina. Historians agree that Roosevelt left no clear guidance for Truman and therefore it is difficult to know with any degree of certainty whether Truman deviated from FDR's desired end state with respect to colonialism. Nevertheless, it is safe to say that Roosevelt practiced an overall anticolonial policy within the constraints of other, more important, foreign policy objectives such as winning the war and maintaining the indispensable coalition of allied nations. This reasoning coincides with the conclusions arrived at by Hess, Miscamble and Thomas in their books. Despite the absence of clear guidance and different management styles, the two Presidents shared similar philosophical outlooks on the evils of imperialism and the need for a world organization of nations to resolve problems without conflict. This philosophy was the guiding light of Truman's anti-colonial policies; yet the environment in which Truman found himself was far from static.

The condition of the world in the postwar period was different from what FDR had faced just months before. Britain and the nations of Western Europe were far frailer than anyone in the United States would have believed possible. Instead of the European empires again becoming dominant players in world politics, as they had been before the war, postwar Britain and Europe required American support just to keep from sliding into chaos. Indeed the world economy was in such dire circumstances and the financial weaknesses of Europe so great that together they threatened any real future economic progress. Additionally, the increasing volatility and calls for nationalism in regions of 
underdeveloped countries made the continuation of European rule unlikely in the eyes of many. The realization of European decline crystallized in the United States when Churchill, whom many had called the defender of the British Empire, failed to win reelection and had to leave office. The newly empowered Labour Party then spent the next seven years downsizing the British Empire. Many people had a sense that FDR's efforts had succeeded and that the tipping point for the demise of imperial colonialism had happened. President Truman certainly felt this way and his speeches referred to the empires as outdated and not relevant to the modern world. He even said that it was a "... historic fact that colonialism had run its course and could no longer be made to work for a few favored nations." Close on the heels of this idea was the realization that if the process was not approached in a controlled, systemic manner it could lead to anarchy in the underdeveloped regions of the world.

The recognition that the European powers were alarmingly weak impacted America's evolving Cold War foreign policy. Truman and his administration needed to keep the United States allies strong enough to confront communism in many regions of the world, which meant the issue of independence for colonies assumed a position of lesser importance. Truman relied upon his advisors and preferred thoughtful interaction and consensus building when making foreign policy decisions. With the exception of Eleanor Roosevelt, few Truman advisors granted ending colonialism a higher priority than maintaining regional stability that was first good for trade and later benefited the conduct of the greater Cold War. The primary colonial issue was the opening of markets to American trade, particularly in the vast British Empire, which the State Department worked hard at during most of the administration. This concern, breaking down 
economic barriers and forcing the opening of markets, is consistent with LaFeber and Ferrell's assertion that closed markets are antithetical to American foreign policy. The Truman State Department was Euro-centric and largely supported the British and French Empires, and lesser European colonial holders, yet this same apparatus still possessed FDR's anti-colonial mindset and pushed these same countries to develop long term plans to divest themselves of colonial holdings. Therefore, the fact that Truman's advisors were Anglophiles was not as big an influence in dealings with the British as implied in Isaacson and Thomas' book. Even the Department of Defense's push to keep control of the Pacific islands did not reflect a desire to establish a colonial structure in the manner of the European empires. Rather, their focus was limited to the concepts of military presence, basing, lines of communication, tactical tripwires and strategic reach.

Truman's rhetoric, as witnessed by his memoirs, correspondence, and public speeches, demonstrated that he personally opposed colonialism. As he said so succinctly, "I had always been opposed to colonialism." If considered from an oratory perspective Truman was no doubt anti-colonial and anti-imperial. If one contemplates his foreign policy decisions with respect to the United Nations, Philippine independence, the Trusteeship Program, the Point Four Program, the attempts to open British colonial markets and the efforts to end Dutch colonial rule in Indonesia, one can find a clear trend against European imperialism. In the case of France, Truman's early position was middle-of-theroad due in part to the mindset that European colonialism was dying a natural death and the hope that the problem would resolve itself without direct United States inference. After all, even FDR had believed that the transition from colony to independent nation would take many years if not decades. Problems arose when the Cold War devolved into 
a clash of surrogates and with France's intransigent insistence upon a system of colonial rule. Still, Truman's actions do not indicate that he wanted to maintain colonialism but, rather, that the Cold War's crisis management overshadowed the issue of independence for the region. Truman's choices are analogous to FDR's earlier decisions to curb anticolonial policies in order to pursue greater wartime goals. Truman firmly believed that colonialism was ending and he judged that the growth of world instability, the need to ensure access to strategic resources, and the fight to curb Communist imperialism were the new dangers for the future.

Many historians and authors have noted that the Cold War changed everything in the way of foreign policy to include priorities. American foreign policy beyond a doubt underwent a fundamental change as conduct of the Cold War overwhelmed all other considerations for the United States. Truman went so far as to transform the issue of the imperialism and anti-colonialism of the old world order into Cold War rhetoric. The idea of colonialism was anathema to American ideals and Communists' forays into the underdeveloped parts of the world faced condemnation in much the same way that the outmoded concept of European colonialism had previously. Truman's speeches were a rallying cry for the United States public; communism was the new, malevolent form of imperialism and Americans must be steadfast in opposition in the name of democracy. 


\section{NOTES}

\section{CHAPTER I: INTRODUCTION}

'Robert H. Ferrell, Harry S. Truman: A Life (Columbia, MO: University of Missouri Press, 1994), 1401 .

${ }^{2}$ Alonzo L. Hamby, Man of the People: A Life of Harry S. Truman (New York: Oxford University Press, 1995), 1-641.

${ }^{3}$ David McCullough, Truman (New York: Simon and Schuster, 1992), 1-992. 45 .

${ }^{4}$ Ronald J. Horvath, "A Definition of Colonialism," Current Anthropology 13, no. 1 (February 1972):

${ }^{5}$ Ibid., 46.

${ }^{6}$ Walter LaFeber, America, Russia, and the Cold War, 1945-2006, $10^{\text {th }}$ ed. (Boston: McGraw-Hill, 2008), 2.

${ }^{7}$ H. L. Wesseling, The European Colonial Empires: 1815-1919, trans. Diane Webb (Harlow, England: Pearson Education Limited, 2004), 144.

${ }^{8}$ Horvath, "A Definition of Colonialism," 50.

'Wesseling, 234-235.

${ }^{10}$ Tbid., 229-234.

"Ibid., 247.

${ }^{12}$ Douglas Johnson, review of Elementary Imperial Military Geography: General Characteristics of the Empire in Relation to Defence, by D. H. Cole, Geographical Review 15, no. 3 (July 1925): 507.

${ }^{13}$ McIntyre, 2.

${ }^{14}$ Luke Johnson, "A Nation of Shopkeepers and World Beaters," Financial Times (London), 16 January $2008,14$.

\section{CHAPTER II: HISTORIOGRAPHICAL REVIEW}

'Edward Crapol, "Some Reflections on the Historiography of the Cold War," The History Teacher, 20, no. 2 (February 1987): 252-253.

${ }^{2}$ Ibid., 253. 
${ }^{3}$ Ibid., 254.

${ }^{4}$ Ibid., 255.

${ }^{3}$ Ibid., 257.

${ }^{6}$ Ibid., 258.

${ }^{7}$ Ibid., 259.

${ }^{8}$ Warren F. Kimball, reviews of The United States and the Origins of the Cold War, 1941-1947, by John L. Gaddis; The Limits of Power: The World and United States Foreign Policy, 1945-1954, by Joyce Kolko and Gabriel Kolko; and The New Left and the Origins of the Cold War, by Robert J. Maddox, The American Historical Review 79, no. 4 (October 1974): 1123-1124.

${ }^{9}$ McCullough, 326.

${ }^{10}$ Ibid., 991 .

"Ibid., 287.

${ }^{12}$ Hamby, 324-325; Wilson D. Miscamble, From Roosevelt to Truman: Potsdam, Hiroshima, and the Cold War (Cambridge, MA: Cambridge University Press, 2007), 89.

${ }^{13}$ Hamby, 638.

${ }^{14}$ Ibid., 641.

${ }^{15}$ John L. Gaddis, The Cold War: A New History (New York: Penguin Group, 2005), 1-333.

${ }^{16}$ Rudolf von Albertini "The Impact of Two World Wars on the Decline of Colonialism," Journal of Contemporary History 4, no. 1, (January 1969): 17-35.

${ }^{17}$ Gaddis, 121 .

${ }^{18}$ Ibid., 123.

${ }^{19}$ LaFeber, America, Russia, and the Cold War, 12.

${ }^{20}$ Ibid., 58.

${ }^{21}$ Walter LaFeber, The American Age: U.S. Foreign Policy at Home and Abroad 1750 to the Present, $2 \mathrm{~d}$ ed. (New York: W.W. Norton \& Company, 1994), 1-842.

${ }^{22}$ Robert H. Ferrell, American Diplomacy: A History, 3d ed. (New York: W.W. Norton \& Company, Inc., 1975), 1-881.

${ }^{23}$ Ibid., 798-799.

${ }^{24}$ LaFeber, The American Age, 351.

${ }^{25}$ Ibid., 432.

${ }^{26}$ Tbid., 418, 433, 437. 
${ }^{27}$ Ibid., 520.

${ }^{28}$ Charles Robertson, International Politics Since World War II: A Short History, 2d ed. (New York: John Wiley \& Sons, Inc., 1975), 1-465.

${ }^{29}$ Ibid., 12.

${ }^{30}$ Ibid., 29, 37-52.

${ }^{31}$ Ibid., 81.

${ }^{32}$ John Spanier, American Foreign Policy Since World War II, $12^{\text {th }}$ ed. (Washington, D.C.: Congressional Quarterly Inc., 1991), 1-443.

${ }^{33}$ Ibid., 80.

${ }^{34}$ Ibid., 48.

${ }^{35}$ Ibid., 172.

${ }^{36}$ William Reitzel, Morton A. Kaplan, and Constance G. Coblenz, United States Foreign Policy 19451955 (Washington D.C.: The Brookings Institution, 1956), 1-535.

${ }^{37}$ Ibid., 45-46.

${ }^{38}$ Ibid., 102.

${ }^{39}$ Tbid., 221-222.

${ }^{40}$ Joan E. Spero, The Politics of International Economic Relations, $4^{\text {th }}$ ed. (New York: St. Martin's Press, 1990), 154-155; Schuyler Foerster and Edward N. Wright, eds., American Defense Policy, $6^{\text {th }}$ ed. (Baltimore: John Hopkins University Press, 1990), 179, 181, 237, 355.

${ }^{41}$ Robert J. Donovan, Conflict and Crisis: The Presidency of Harry S Truman, 1945-1948 (New York: W.W. Norton \& Company, Inc., 1977), 1-473.

${ }^{42}$ Ibid., 6.
${ }^{43}$ Ibid., 43.
${ }^{44}$ Ibid., 61.
${ }^{45}$ Ibid., 87.

${ }^{46}$ Walter Isaacson and Evan Thomas, The Wise Men: Six Friends and the World They Made (New York: Touchstone, Simon \& Schuster Inc., 1988), 1-853.

${ }^{47}$ Ibid., 256.

${ }^{48}$ Ibid., 255-257.

${ }^{49}$ Ibid., 386-387.

${ }^{50}$ Ibid., 393. 
${ }^{51}$ Ibid., 478.

${ }^{52}$ Melvyn P. Leffler, A Preponderance of Power: National Security, the Truman Administration, and the Cold War (Stanford, CA: Stanford University Press, 1992), 1-689.

${ }^{53}$ Ibid., 9.

${ }^{54}$ Ibid., 30.

${ }^{55}$ Ibid., 16.

${ }^{56}$ Ibid., 17.

${ }^{37}$ Ibid., 94 .

${ }^{38}$ Ibid., 166-167.

${ }^{59}$ Ibid., 92.

${ }^{60}$ Ibid., 97.

${ }^{61}$ Bbid., 165.

${ }^{62}$ John J. Sebrega, "The Anticolonial Policies of Franklin D. Roosevelt: A Reappraisal," Political Science Quarterly 101, no. 1 (1986): 77; Foster R. Dulles and Gerald E. Ridinger, "The Anti-Colonial Policies of Franklin D. Roosevelt," Political Science Quarterly 70, no. 1. (March 1955): 1.

${ }^{63}$ Thomas G. Paterson, ed., Major Problems in American Foreign Policy Volume II: Since 1914, 3d ed. (Lexington, MA: D.C. Heath and Company, 1989), 1-721.

${ }^{64}$ Paterson, 246-260: Gary R. Hess, The United States at War, 1941-1945 (Arlington Heights, Ill: Harlan Davidson, 1986), 102-26.

${ }^{65}$ Ibid., 247.

${ }^{66}$ Ibid., 240.

${ }^{67}$ Ibid., 247.

${ }^{68}$ Ibid., 258-259.

${ }^{69}$ Thomas C. Howard and William D. Pederson, eds., Franklin D. Roosevelt and the Formation of the Modern World (Armonk, NY: M. E. Sharpe, Inc., 2003), 1-261.

${ }^{70}$ Ibid., 157.

${ }^{71}$ Ibid., 162.

${ }^{72}$ Gary R. Hess, "Franklin Roosevelt and Indochina," The Journal of American History 59, no. 2. (September 1972): $365,367$.

${ }^{73}$ Miscamble, 1-393.

${ }^{74}$ Ibid., 42. 
${ }^{75}$ Ibid., 35-38.

${ }^{76}$ Ibid., 39.

${ }^{77}$ Sebrega, "The Anticolonial Policies of Franklin D. Roosevelt," 82.

${ }^{78}$ John L. Gaddis, Strategies of Containment: A Critical Appraisal of Postwar American National Security Policy (Oxford: Oxford University Press, 1982), 11.

${ }^{79}$ Walter LaFeber, "Roosevelt, Churchill, and Indochina: 1942-45," The American Historical Review 80, no. 5. (December 1975): 1277.

${ }^{80}$ Miscamble, 47.

${ }^{81}$ Brian Lapping, End of Empire (New York: St. Martin's Press, 1985), 5.

${ }^{82}$ W. David McIntyre, British Decolonization, 1946-1997: When, Why and How did the British Empire Fall? (New York: St. Martin's Press, 1998), 1-176.

${ }^{83}$ Ibid., 90 .

${ }^{84}$ Lapping, 1-560.

${ }^{85}$ Ibid., xvi.

${ }^{86}$ Ibid., 123.

${ }^{87}$ Terry H. Anderson, The United States, Great Britain, and the Cold War: 1944-1947 (Columbia, MO: University of Missouri Press, 1981), 1-256.

${ }^{88}$ Ibid., 5 .

${ }^{89}$ Tbid., 63.

${ }^{90}$ Tbid., 64.

${ }^{91}$ Ibid., 118.

${ }^{92}$ Ibid., 179.

${ }^{93}$ Ibid., 123.

${ }^{94}$ Peter L. Hahn, The United States, Great Britain, and Egypt, 1945-1956: Strategy and Diplomacy in the Early Cold War (Chapel Hill, NC: The University of North Carolina Press, 1991), 1-376.

${ }^{95}$ Ibid., 20-21.

${ }^{96}$ Robert J. McMahon, ed. Major Problems in the History of the Vietnam War: Documents and Essays, 3d ed. (Boston: Houghton Mifflin Company, 2003), 1-539.

${ }^{97}$ Ibid., 75 .

${ }^{98}$ Mike Gravel, introduction to The Pentagon Papers: The Defense Department History of United States Decisionmaking on Vietnam Volume I, The Senator Gravel ed. (Boston: Beacon Press, 1971), 2. 
${ }^{99}$ Tbid., 49-50.

${ }^{100}$ Loren Baritz, Backfire: A History of How American Culture Led Us Into Vietnam and Made Us Fight the Way We Did (1985; repr., Baltimore: John Hopkins University Press, 1998), 1-393.

${ }^{101}$ Ibid., 62-73.

${ }^{102}$ LaFeber, America, Russia, and the Cold War, 2, 172.

\section{CHAPTER III: FRANKLIN D. ROOSEVELT / WORLD WAR TWO}

'Paterson, 289.

${ }^{2}$ Anderson, 2.

${ }^{3}$ Ibid.

${ }^{4}$ Bailey, 376.

${ }^{5}$ Ibid.

${ }^{6}$ Ibid., 3.

${ }^{7}$ Robert Dallek, Franklin D. Roosevelt and American Foreign Policy, 1932-1945 (New York: Oxford University Press, 1979), 324.

${ }^{8}$ McIntyre, 90.

${ }^{9}$ Ibid.

${ }^{10}$ William R. Louis, "American Anti-Colonialism and the Dissolution of the British Empire," International Affairs 61, no. 3. (Summer 1985): 399.

Il" An Open Letter from the Editors of LIFE to the People of England," Life Magazine. 12 October 1942, 34.

${ }^{12}$ Anderson, 5.

${ }^{13}$ Ibid., 183.

${ }^{14}$ Ibid., 5.

${ }^{15}$ Ibid.

${ }^{16}$ Paterson, 258.

${ }^{17}$ Elbert G. Mathews, interview by Richard D. McKinzie, transcript, 13 June 1975, Oral History Collection, Truman Library, Independence, MO, 17.

${ }^{18}$ Paterson, 264.

${ }^{19}$ LaFeber, The American Age, 351. 
${ }^{20}$ John M. Leddy, interview by Richard D. McKinzie, transcript, 15 June 1973, Oral History Collection, Truman Library, Independence, MO, 18-21.

${ }^{21}$ McMahon, Major Problems in the History of the Vietnam War, 61.

${ }^{22}$ Howard, 157.

${ }^{23}$ Sebrega, "The Anticolonial Policies of Franklin D. Roosevelt," 65.

${ }^{24}$ Dallek, 7.

${ }^{25}$ Ibid., 109.

${ }^{26}$ Ibid., 283.

${ }^{27}$ Thomas A. Bailey, A Diplomatic History of the American People (Englewood Cliffs, NJ: Prentice Hall Inc., 1974), 767; Miscamble, 40.

${ }^{28}$ Paterson, 247.

${ }^{29}$ Bailey, 729.

${ }^{30}$ McMahon, Major Problems in the History of the Vietnam War, 74.

${ }^{31}$ Miscamble, 42.

${ }^{32}$ Bailey, 728-729.

${ }^{33}$ Dulles, "The Anticolonial Policies of Franklin D. Roosevelt," 4.

${ }^{34}$ Anderson, 5 .

${ }^{35}$ Gaddis, Strategies of Containment, 11.

${ }^{36}$ Robertson, 14.

${ }^{37}$ Paterson, 264.

${ }^{38}$ McIntyre, 89.

${ }^{39}$ Dulles, "The Anticolonial Policies of Franklin D. Roosevelt," 16.

${ }^{40}$ Miscamble, 43.

${ }^{41}$ LaFeber, The American Age, 418.

${ }^{42}$ Francis L. Loewenheim, Harold D. Langley, and Manfred Jonas, eds., Roosevelt and Churchill: Their Secret Wartime Correspondence (New York: Saturday Review Press and E.P. Dutton \& Co., Inc., 1975), 176.

${ }^{43}$ Louis, "American Anti-Colonialism," 402.

${ }^{44}$ Howard, 158. 
${ }^{45}$ McIntyre, 24.

${ }^{46}$ Loewenheim, 184.

${ }^{47}$ Ibid., 192.

${ }^{48}$ Miscamble, 44, 46.

${ }^{49}$ McMahon, Major Problems in the History of the Vietnam War, 74-75.

${ }^{50}$ Howard, 162.

${ }^{51}$ Paterson, 258.

${ }^{52}$ LaFeber, The American Age, 437.

${ }^{53}$ Dallek, 459.

${ }^{54}$ Paterson, 259.

${ }^{55}$ Dallek, 459; Sebrega, "The Anticolonial Policies of Franklin D. Roosevelt," 79.

${ }^{56}$ Paterson, 259.

${ }^{57}$ McMahon, Major Problems in the History of the Vietnam War, 74.

${ }^{58}$ Mark A. Lawrence and Fredrik Logevall, The First Vietnam War: Colonial Conflict and Cold War Crisis (Cambridge, MA: Harvard University Press, 2007), 74.

${ }^{59}$ Howard, 164.

${ }^{60}$ George M. Kahin, INTERVENTION: How America Became Involved in Vietnam (New York: Alfred A. Knopf, 1986), 4; Sebrega, "The Anticolonial Policies of Franklin D. Roosevelt," 69-70.

${ }^{61}$ Howard, 165.

${ }^{62}$ Ibid.

${ }^{63}$ Sebrega, "The Anticolonial Policies of Franklin D. Roosevelt," 76.

${ }^{64}$ McMahon, 75.

${ }^{65}$ Paterson, 259-260; Gary Hess, "Franklin Roosevelt and Indochina," 360.

${ }^{66}$ Miscamble, 35.

${ }^{67}$ Sebrega, "The Anticolonial Policies of Franklin D. Roosevelt," 79.

${ }^{6.8}$ McMahon, 75; Paterson 259.

${ }^{69}$ Sebrega, "The Anticolonial Policies of Franklin D. Roosevelt," 77.

${ }^{70}$ Ibid., 74.

${ }^{71}$ Paterson, 260. 


\footnotetext{
${ }^{72}$ Miscamble, 38.

${ }^{73}$ Miscamble, 38.

${ }^{74}$ Paterson, 258.

${ }^{75}$ Sebrega, "The Anticolonial Policies of Franklin D. Roosevelt," 72.

${ }^{76}$ Gaddis, The Cold War, 121.

${ }^{77}$ Harry S. Truman, Memoirs by Harry S. Truman Volume One: Year of Decisions (Garden City, NY: Doubleday and Company, 1955), 237.

${ }^{78}$ Andreas Dorpalen, Europe in the $20^{\text {th }}$ Century: A History (New York: The Macmillan Company, 1968), 431.

${ }^{79}$ LaFeber, America, Russia, and the Cold War, 58.

${ }^{80}$ Ibid.
}

\section{CHAPTER IV: HARRY S. TRUMAN}

'Anderson, 53.

${ }^{2}$ Miscamble, 31.

${ }^{3}$ Anderson, 54; Miscamble, 31.

${ }^{4} \mathrm{McCullough,} 355$.

${ }^{5}$ Miscamble, 83.

${ }^{6}$ McCullough, 355.

${ }^{7}$ Miscamble, 104.

${ }^{8}$ Anderson, 55.

${ }^{9}$ Robert H. Ferrell, Off the Record: The Private Papers of Harry S. Truman (New York: Harper Row Publishers, 1980), 187.

${ }^{10}$ Dallek, 3.

${ }^{11}$ Anderson, 54.

${ }^{12}$ Reitzel, 45-46.

${ }^{13}$ Miscamble, 31 .

${ }^{14}$ Ibid., 36-38.

${ }^{15}$ Hamby, 13. 
${ }^{16}$ Miscamble, 10.

${ }^{17}$ Ibid., 89.

${ }^{18}$ Isaacson, $256-257$.

${ }^{19}$ Miscamble, 93.

${ }^{20}$ Hamby, 572.

${ }^{21}$ Miscamble, 33.

${ }^{22}$ Miscamble, 13.

${ }^{23}$ Henry Pirtle comp., Kentucky Monitor: Complete Monitorial Ceremonies of the Blue Lodge, $17^{\text {th }}$ ed. (Louisville, KY: Grand Lodge of Kentucky Free and Accepted Masons, 1979), 4; Miscamble, 13.

${ }^{24}$ Merle Miller, Plain Speaking An Oral Biography of Harry S. Truman (Berkley, CA: Berkley Publishing Corporation, 1973), 155.

${ }^{25}$ Miscamble, 33.

${ }^{26}$ Ibid., 187.

${ }^{27}$ Miscamble, 8.

${ }^{28}$ Ibid., 7.

${ }^{29}$ Harry S. Truman, Public Papers of the Presidents of the United States: Containing the Public Messages, Speeches, and Statements of the President January 1 to December 31, 1948 (Washington, D.C.: United States Government Printing Office, 1964), 928.

${ }^{30}$ Miscamble, 11.

${ }^{31}$ Anderson, 54; Isaacson, 256.

${ }^{32}$ Truman, Public Papers 1948, 343.

${ }^{33}$ Harry S. Truman, Public Papers of the Presidents of the United States: Containing the Public Messages, Speeches, and Statements of the President January 1 to December 31, 1950 (Washington, D.C.: United States Government Printing Office, 1965), 404.

${ }^{34}$ Miscamble, 323.

${ }^{35}$ Truman, Year of Decisions, 275.

${ }^{36}$ Ibid., 362.

${ }^{37}$ Ibid., 275.

${ }^{38}$ Harry S. Truman, Public Papers of the Presidents of the United States: Containing the Public Messages, Speeches, and Statements of the President January 1, 1952, to January 20, 1953 (Washington, D.C.: United States Government Printing Office, 1965), 1124. 
${ }^{39}$ Harry S. Truman, Memoirs by Harry S. Truman Volume Two: Years of Trial and Hope, Garden City, NY: Doubleday and Company, 1956, 228.

${ }^{40}$ Truman, Public Papers 1948, 8.

${ }^{41}$ Anderson, 53.

${ }^{42}$ Truman, Public Papers 1950, 402-403.

${ }^{43}$ Ibid., 402.

${ }^{44}$ Miscamble, 26.

${ }^{45}$ Harry S. Truman, Public Papers of the Presidents of the United States: Containing the Public Messages, Speeches, and Statements of the President January I to December 31, 1947 (Washington, D.C.: United States Government Printing Office, 1963), 167-172.

${ }^{46}$ Truman, Public Papers 1947, 170.

${ }^{47}$ Ibid., 171-172.

${ }^{48}$ Harry S. Truman, Public Papers of the Presidents of the United States: Containing the Public Messages, Speeches, and Statements of the President January 1 to December 31, 1949 (Washington, D.C.: United States Government Printing Office, 1964), 486.

${ }^{49}$ Ibid.

${ }^{50}$ Miscamble, $41,107$.

${ }^{51}$ Truman, Public Papers 1947, 325.

${ }^{52}$ Harry S. Truman, Public Papers of the Presidents of the United States: Containing the Public Messages, Speeches, and Statements of the President January 1 to December 31, 1946 (Washington, D.C.: United States Government Printing Office, 1962), 45.

${ }^{53}$ Anderson, 181.

${ }^{54}$ LaFeber, America, Russia, and the Cold War, 50.

${ }^{55}$ Jack Hess, telegram to the President, 3 September 1947, President's Secretary's Files: Truman Papers, Truman Library, Independence, MO.

${ }^{56}$ Isaacson, 270.

${ }^{57}$ Anderson, 63.

${ }^{58}$ U.S. Department of State, Foreign Relations of the United States 1947: Volume III The British Commonwealth; Europe (Washington D. C.: U.S. Government Printing Office, 1972), 34-35.

${ }^{59}$ Richard S. Kirkendall, ed., The Truman Period As A Research Field: A Reappraisal, 1972 (Columbia, MO: University of Missouri Press, 1974), 164; LaFeber, America, Russia, and the Cold War, 172; Hamby, 394.

${ }^{60}$ Harry S. Truman, Excerpts of a Conversation with Mr. Harris, n.d. transcript, Post Presidential Files Box 644: Truman Papers, Truman Library, Independence, MO, 4. 
${ }^{61}$ Truman, Year of Decisions, 480.

${ }^{62}$ Ibid., 275.

${ }^{63}$ Ibid., 195.

${ }^{64}$ Leffler, A Preponderance of Power, 26.

${ }^{65}$ Isaacson, 254.

${ }^{66} \mathrm{McC}$ cullough, 354.

${ }^{67}$ Miscamble, 96.

${ }^{68} \mathrm{McCullough,} 355$.

${ }^{69}$ Anderson, 54.

${ }^{70}$ Miscamble, 89.

${ }^{71}$ Miscamble, 10, 37, 142.

${ }^{72}$ Ibid., 92.

${ }^{73}$ Hamby, 314.

${ }^{74}$ Hamby, 314, 409; Miscamble, 142.

${ }^{75}$ Hamby, 409.

${ }^{76}$ McCullough, 619.

${ }^{77}$ Leffler, A Preponderance of Power, 62.

${ }^{78}$ Peter Hahn, 20.

${ }^{79}$ McCullough, 399-400.

${ }^{80}$ Harry S. Truman, "Excerpts from Draft Memoirs," 966-979.

${ }^{81}$ Ibid., 966-967.

${ }^{82}$ Ibid., 969-972.

${ }^{83}$ Ibid., 972-974.

${ }^{84}$ Ibid., 974-978

${ }^{85}$ Ibid., 979-980.

${ }^{86}$ Hamby, 306.

${ }^{87}$ Leffler, A Preponderance of Power, 27-28. 
${ }^{88}$ Leffler, A Preponderance of Power, 27; Hamby, 279-284.

${ }^{89}$ Truman, Year of Decisions, 549-552; Isaacson, 245-346, 390; Hamby, 388.

${ }^{90}$ Truman, Years of Trial and Hope, 112.

${ }^{91}$ Leffler, $A$ Preponderance of Power, 28, 142, 174; Truman, Years of Trial and Hope, 112-1.15.

${ }^{92}$ Hamby, 409.

${ }^{93}$ Miller, 84-85, 169.

${ }^{94} \mathrm{McC}$ cullough, 614-620.

${ }^{95}$ Miscamble, 308.

${ }^{96}$ McCullough, 589.

${ }^{97}$ McCullough, 583.

${ }^{98}$ Joseph G. Feeney, interview by Jerry N. Hess, transcript, 20 September 1966, Oral History Collection, Truman Library, Independence, MO, 124.

${ }^{99}$ Leffler, A Preponderance of Power, 165; Robertson, 77.

${ }^{100}$ Miscamble, 311.

${ }^{101}$ Isaacson, 270.

${ }^{102}$ Dean Acheson, Present at the Creation: My Years in the State Department (New York: W.W. Norton \& Company, Inc., 1969), 387.

${ }^{103}$ John T. McNay, "Imperial Paradigm: Dean Acheson and American Foreign Policy," (Ph.D. diss., Temple University, 1997), 6.

${ }^{104}$ Donovan, 87.

${ }^{105}$ Acheson, Present at the Creation, 387.

${ }^{106}$ John F. Cady, interview by Richard D. McKinzie, transcript, 31 July 1974, Oral History Collection, Truman Library, Independence, MO, 56.

${ }^{107}$ LaFeber, America, Russia, and the Cold War, 116.

${ }^{108}$ Allida M. Black, Casting Her Own Shadow: Eleanor Roosevelt and the Shaping of Postwar Liberalism (New York: Columbia University Press, 1996), 3-4.

${ }^{109}$ Hamby, 319, 355-356.

${ }^{110}$ Margaret E. Galey, "The Universal Declaration of Human Rights: The Role of Congress," PS: Political Science and Politics, 31, no. 3. (September 1998), 524.

${ }^{11}$ Geoffrey C. Ward review of ELEANOR AND HARRY: The Correspondence of Eleanor Roosevelt and Harry S. Truman, ed. Steven Neal. New York Times, 25 August 2002, 9. 
${ }^{112}$ Miller, 220.

${ }^{113}$ McCullough, 482.

${ }^{114}$ Eleanor Roosevelt Letter to President Harry S. Truman, 20 November 1945, President's Secretary's Files: Truman Papers, Truman Library, Independence, MO.

${ }^{115}$ Eleanor Roosevelt Letter to President Harry S. Truman, 6 May 1951, President's Secretary's Files: Truman Papers, Truman Library, Independence, MO.

${ }^{116}$ Eleanor Roosevelt Letter to President Harry S. Truman, 14 December 1950, Official File: Truman Papers, Truman Library, Independence, MO.

${ }^{117}$ Eleanor Roosevelt Letter to President Harry S. Truman, 17 April 1947, President's Secretary's Files: Truman Papers, Truman Library, Independence, MO.

${ }^{118}$ Acheson, Present at the Creation, 638.

${ }^{119}$ David P. Forsythe, "Human Rights in U.S. Foreign Policy: Retrospect and Prospect," Political Science Quarterly 105, no. 3 (Autumn 1990), 436.

${ }^{120}$ Galey, 524.

${ }^{121}$ McCullough, 991.

${ }^{122}$ Anderson, 73.

${ }^{123}$ Harry S. Truman, Strictly Personal and Confidential: The Letters Harry Truman Never Mailed, ed. Monte M. Poen, (Boston: Little, Brown and Company, 1982), 32-33.

${ }^{124}$ Miscamble, 211-214.

${ }^{125}$ Anderson, 127.

${ }^{126}$ Truman, Year of Decisions, 374.

${ }^{127}$ U.S. Central Intelligence Agency, ORE 39: Significant Considerations Regarding the Disposition of the Italian African Colonies (Declassified), President's Secretary's Files: Truman Papers, Truman Library, Independence, MO, 25 July 1947, 1.

${ }^{128}$ Ibid., 8.

${ }^{129}$ John W. Jones, interview by Richard D. McKinzie, transcript, 8 June 1974, Oral History Collection, Truman Library, Independence, MO, 36-37.

${ }^{130}$ Mclntyre, 1 .

${ }^{131}$ Donovan, 102.

${ }^{132}$ Truman. Strictly Personal and Confidential, 153; Miller, 199. 
${ }^{133}$ Robert P. Watson, Michael J. Devine, and Robert J. Wolz, eds., The National Security Legacy of Harry S. Truman: Volume I (Kirksville, MO: Truman State University Press, 2005), 144-145.

${ }^{134}$ McCullough, 287.

${ }^{135}$ Miller 199.

${ }^{136}$ Truman, Year of Decisions, 323.

${ }^{137}$ Harding F. Bancroft, interview by Richard D. McKinzie, transcript, 25 June 1974, Oral History Collection, Truman Library, Independence, MO, 34.

${ }^{138}$ Miscamble, 27, 90.

${ }^{139}$ Isaacson, 269.

${ }^{140}$ Truman, Year of Decisions, 237-238.

${ }^{141}$ Thomas M. Campbell, "Nationalism in America's UN Policy, 1944-1945," International Organization 27, no. 1 (Winter 1973): 26.

${ }^{142}$ Truman, Public Papers 1948, 542.

${ }^{143}$ Truman, Public Papers 1950, 434.

${ }^{144}$ Tbid., 435.

${ }^{145}$ Miller, 216.

${ }^{146}$ Robertson, 17; Howard, 158-159.

${ }^{147}$ Howard, 162.

${ }^{148}$ Campbell, "Nationalism in America's UN Policy," 32.

${ }^{149}$ Paterson, 239-240; Howard, 165.

${ }^{150}$ Gary Hess, "Franklin Roosevelt and Indochina," 365-367.

${ }^{151}$ Stephen C. Schlesinger, Act of Creation: The Founding of the United Nations (Boulder, CO: Westview Press, 2003), 235.

${ }^{152}$ Truman, Public Papers 1946, 121.

${ }^{153}$ Truman, Year of Decisions, 273.

${ }^{154}$ Truman, "Excerpts from Draft Memoirs," 820.

${ }^{155}$ Ibid.

${ }^{156}$ Ibid., 833.

${ }^{157}$ Schlesinger, 235-236. 
${ }^{158}$ John E. Orchard, "ECA and the Dependent Territories," Geographical Review 41, no. 1 (January 1951): 66 .

${ }^{159}$ Paterson, 240.

${ }^{160}$ Schlesinger, 234.

${ }^{161}$ Truman, Public Papers 1947, 287.

${ }^{162}$ Schlesinger, 232.

${ }^{163}$ U.S. Department of State, "Official Trust Territories of the Pacific," map, reprinted from the map collection of the University of Hawaii's Manoa Hamilton Library, this map is a work of the United States Federal Government and under the terms of Title 17, Chapter 1, Section 105 of the US Code is in the public domain, 1962.

${ }^{164}$ Truman, Year of Decisions, 274.

${ }^{165}$ Leffler, A Preponderance of Power, 56.

${ }^{166}$ Schlesinger, 79; Campbell, "Nationalism in America's UN Policy," 32.

${ }^{167}$ Truman, Public Papers 1946, 20.

${ }^{168}$ Ibid., 92.

${ }^{169}$ Michael J. McDermott, Memorandum to Charles G. Ross, Draft Press Statement on the Establishment of the South Pacific Commission, 21 January 1948, President's Secretary's Files: Truman Papers, Truman Library, Independence, MO.

${ }^{170}$ Howard, 165.

${ }^{171}$ James Forrestal, The Forrestal Diaries, ed. Walter Millis with collaboration of E. S. Duffield (New York: The Viking Press, 1951), 28.

${ }^{172}$ Schlesinger, 79; Kahin, 4; Truman, Year of Decisions, 274-275.

${ }^{173}$ James N. Murray Jr., The United Nations Trusteeship System (Urbana, IL: The University of Illinois Press 1957), 29.

${ }^{174}$ Forrestal, 131.

${ }^{175}$ Ibid., 213-214.

${ }^{176}$ Truman, Year of Decisions, 274.

${ }^{177}$ Truman, Public Papers 1946, 474.

${ }^{178}$ Ibid.

${ }^{179}$ Truman, Year of Decisions, 275.

${ }^{180}$ Truman, Public Papers 1950, 671. 
${ }^{181}$ Truman, Year of Decisions, 275.

${ }^{182}$ Leffler, A Preponderance of Power, 94.

${ }^{183}$ Bailey, 787.

${ }^{184}$ Harry S. Truman, Public Papers of the Presidents of the United States: Containing the Public Messages, Speeches, and Statements of the President April 12 to December 31, 1945 (Washington, D.C.: United States Government Printing Office, 1961), 397.

${ }^{185}$ Ibid.

${ }^{186}$ Ibid.

${ }^{187}$ Truman, Public Papers 1950, 695.

${ }^{188}$ McCullough, 812; Walter LaFeber, The American Age: U.S. Foreign Policy at Home and Abroad 1750 to the Present, 2 d ed. (New York: W.W. Norton \& Company, 1994), 212; John Garraty and Peter Gay, eds., The Columbia History of the World (New York: Harper \& Row, 1972), 936-937.

${ }^{189}$ Truman, Years of Trial and Hope, 311.

${ }^{190}$ Miscamble, 325.

${ }^{191}$ Dean Acheson, interview by Theodore A. Wilson and Richard D. McKinzie, transcript, 30 June 1971, Oral History Collection, Truman Library, Independence, MO, 5.

${ }^{192}$ Spanier, 48; McIntyre, 84.

${ }^{193}$ Anderson, 166.

${ }^{194}$ Michael Lind, Vietnam: The Necessary War (New York: Simon \& Schuster, 1999), 6.

${ }^{195}$ McCullough, 540.

${ }^{196}$ Robertson, 37 .

${ }^{197}$ Spanier, 49.

${ }^{198}$ Ibid.

${ }^{199}$ Press Release, Statement by the President, TD, apparently written by the President's staff in the White House, 13 February 1947, President's Secretary's Files: Truman Papers, Truman Library, Independence, MO.

${ }^{200}$ Miller, 241.

${ }^{201}$ Robertson, 42.

${ }^{202}$ U.S. Central Intelligence Agency, ORE 25-48: The Break-up of the Colonial Empires and its Implications for US Security (Declassified), President's Secretary's Files: Truman Papers, Truman Library, Independence, MO, 3 September 1948, 1-3.

${ }^{203}$ U.S. Central Intelligence Agency, National Intelligence Estimate (NIE-26): Key Problems Affecting US Efforts to Strengthen the Near East (Declassified), President's Secretary's Files: Truman Papers, 
Truman Library, Independence, MO, 25 April 1951, 1; U.S. Central Intelligence Agency, Special Estimate (SE-32): Consequences of Communist Control Over South Asia (Declassified), President's Secretary's Files: Truman Papers, Truman Library, Independence, MO, 3 October 1952, 1-7.

${ }^{204}$ U.S. Central Intelligence Agency, Special Report (SR-25): United Kingdom (Declassified), President's Secretary's Files: Truman Papers, Truman Library, Independence, MO, 7 December 1949, 1-8; U.S. Central Intelligence Agency, ORE 79-49: US Security and the British Dollar Problem (Declassified), President's Secretary's Files: Truman Papers, Truman Library, Independence, MO, 31 August 1949, 1-5; U.S. Central Intelligence Agency, ORE 93-49: The Possibility of Britain's Abandonment of Overseas Military Commitments (Declassified), President's Secretary's Files: Truman Papers, Truman Library, Independence, MO, 23 December 1949, 1.

${ }^{205}$ U.S. Central Intelligence Agency, $S R-25,2$.

${ }^{206}$ Ibid., 6-7.

${ }^{207}$ Ibid., 7.

${ }^{208}$ U.S. Central Intelligence Agency, National Intelligence Estimate (NIE-23): India's Position in the East-West Conflict (Declassified), President's Secretary's Files: Truman Papers, Truman Library, Independence MO, 4 September 1951, 2.

${ }^{209}$ U.S. Central Intelligence Agency, NIE-26, 1.

${ }^{210}$ U.S. Central Intelligence Agency, ORE 33-49: Current Situation in Malaya (Declassified), President's Secretary's Files: Truman Papers, Truman Library, Independence, MO, 17 November 1949, 12.

${ }^{211}$ U.S. Central Intelligence Agency, ORE 46-50: The Current Situation in British West Africa (Declassified), President's Secretary's Files: Truman Papers, Truman Library, Independence, MO, 29 September 1950, 1 .

${ }^{212}$ U.S. Central Intelligence Agency, ORE 64: The Current Situation in France (Declassified), President's Secretary's Files: Truman Papers, Truman Library, Independence, MO, 31 December 1947, 1, 6.

${ }^{213}$ Ibid., 6.

${ }^{214}$ Ibid., 1 .

${ }^{215}$ U.S. Central Intelligence Agency, Special Report (SR-30): France (Declassified), President's Secretary's Files: Truman Papers, Truman Library, Independence, MO, 17 March 1950, 17.

${ }^{216}$ U.S. Central Intelligence Agency, Memorandum for the NSC Senior Staff Prepared to Supplement NIE-69, Probable Developments in North Africa: The Current Situation in North Africa (Declassified), President's Secretary's Files: Truman Papers, Truman Library, Independence, MO, 12 September 1952, 1.

${ }^{217}$ U.S. Central Intelligence Agency, ORE 63: The Current Situation in French North Africa (Declassified), President's Secretary's Files: Truman Papers, Truman Library, Independence, MO, 18 December 1947, 1.

${ }^{218}$ U.S. Central Intelligence Agency, National Intelligence Estimate (NIE-5): Indochina: Current Situation and Probable Developments (Declassified), President's Secretary's Files: Truman Papers, Truman Library, Independence, MO, 29 December 1950, 1-2. 
${ }^{219}$ U.S. Central Intelligence Agency, National Intelligence Estimate (NIE-35/1): Probable Developments in Indochina through Mid-1952 (Declassified), President's Secretary's Files: Truman Papers, Truman Library, Independence, MO, 3 March 1952, 1.

${ }^{220}$ Ibid.

${ }^{221}$ U.S. Central Intelligence Agency, Special Report (SR-31): Portugal (Declassified), President's Secretary's Files: Truman Papers, Truman Library, Independence, MO, 13 October 1949, 1.

${ }^{222}$ U.S. Central Intelligence Agency. Office of Reports and Estimates, ORE 26-48: The Prospects for a United States of Indonesia (Declassified), President's Secretary's Files: Truman Papers, Truman Library, Independence, MO, 4 June 1948, 1.

${ }^{223}$ U.S. Central Intelligence Agency, ORE 40-49: Consequences of Dutch "Police Action" in Indonesia (Declassified), President's Secretary's Files: Truman Papers, Truman Library, Independence, MO, 27 January $1949,1-4$.

${ }^{224}$ Ibid., 1-4.

${ }^{225}$ Ibid., 4.

${ }^{226}$ Robertson, 106.

${ }^{227}$ Truman, Public Papers of the Presidents of the United States: Containing the Public Messages, Speeches, and Statements of the President January I to December 31, 1951 (Washington, D.C.: United States Government Printing Office, 1965), 4, 11, 13, 18, 20, 54, 59, 68, 70, 76, 78, 80, 83, 90, 96, 107, 114, 116, 123, 138, 144, 167, 170, 174, 191, 197, 199, 209, 213, 225, 253, 279, 293, 297.

${ }^{228}$ Truman, Public Papers 1948, 337.

${ }^{229}$ McMahon, 85.

${ }^{230}$ James L. Roark, "American Black Leaders: the Response to Colonialism and the Cold War, 19431953," African Historical Studies 4, no. 2 (1971): 260.

${ }^{231}$ Ibid., 263-264.

${ }^{232}$ Francis O. Wilcox, interview by Donald A. Ritchie, transcript, 13 April 1984, Oral History Collection, Truman Library, Independence, MO, 190.

${ }^{233}$ Bancroft, 25.

${ }^{234}$ Truman, Years of Trial and Hope, 237.

${ }^{235}$ Spyros Markezinis, interview by Theodore A. Wilson, transcript, 22 July 1970, Oral History Collection, Truman Library, Independence, MO.

${ }^{236}$ Acheson, Present at the Creation, 765.

${ }^{237}$ Reitzel, 102.

${ }^{238}$ Ibid., 257.

${ }^{239}$ Truman, Public Papers 1950, 446, 609, 613, 705; Truman, Public Papers 1951, 267. 
${ }^{240}$ Truman, Public Papers 1950, 446.

${ }^{241}$ Harry S. Truman, "Address Opening the Meeting of the Foreign Ministers of the American Republics," (speech presented at the fourth meeting of Consultation of Ministers of Foreign Affairs of American States, Washington, D.C., 26 March 1951).

${ }^{242}$ Harry S. Truman, "Address at the San Francisco War Memorial Opera House," (speech, San Francisco, CA, 17 October 1950).

${ }^{243}$ National Security Council Report, NSC 68: United States Objectives and Programs for National Security (Declassified), President's Secretary's Files: Truman Papers, Truman Library, Independence, MO, 14 April 1950, 14.

${ }^{244}$ Ebere Nwaubani, “The United States and the Liquidation of European Colonial Rule in Tropical Africa, 1941-1963," Cahiers d'Études africaines 171 (2003): 519.

${ }^{245}$ Truman, Years of Trial and Hope, 228.

${ }^{246}$ Harry S. Truman, “Campaign Speech at Campagnone Memorial Common," (speech, Lawrence, MA, 17 October 1952).

${ }^{247}$ Edwin P. Reubens, "Asia and Truman's Fourth Point," Far Eastern Survey 18, no. 6 (March 1949): 61-67.

${ }^{248}$ Robertson, 81-82.

${ }^{249}$ Leffler, A Preponderance of Power, 267; "Point Four and the U.N.," New York Times, 12 November $1949,14$.

${ }^{250}$ Truman, Public Papers 1952 to 1953, 1124.

${ }^{251}$ Truman, Public Papers 1950, 5.

${ }^{252}$ Truman, Public Papers 1950, 623.

${ }^{253}$ Truman, Public Papers 1951, 304.

${ }^{254}$ Truman, Public Papers 1952 to 1953, 185.

${ }^{255}$ Samuel P. Hayes, "Statistics in the Point IV Program," The American Statistician, 4, no. 1. (February 1950), 4-5.

${ }^{256}$ Truman, Years of Trial and Hope, 231.

${ }^{257}$ Ibid.

${ }^{258}$ Ibid., 232.

${ }^{259}$ Acheson, Present at the Creation, 264-266; Isaacson, 732.

${ }^{260}$ Donovan, 87.

${ }^{261}$ Anderson, 123. 
${ }^{262}$ Peter Weiler, "British Labour and the Cold War: The Foreign Policy of the Labour Governments, 1945-1951," The Journal of British Studies 26, no. 1 (January 1987): 70; James T. H. Tang, "From Empire Defence to Imperial Retreat: Britain's Postwar China Policy and the Decolonization of Hong Kong," Modern Asian Studies 28, no. 2 (May 1994): 319.

${ }^{263}$ McIntyre, 21.

${ }^{264}$ Robertson, 51 .

${ }^{265}$ Dorpalen, 431.

${ }^{266}$ Anderson, 123; Dorpalen, 431.

${ }^{267}$ McIntyre, 1.

${ }^{268}$ McIntyre, 38; Truman, Years of Trial and Hope, 259.

${ }^{269}$ Henry A. Kissinger, Diplomacy (New York: Simon \& Schuster, 1994), 442-443, 466-467; Miscamble, 203, 281.

${ }^{270}$ Truman, Public Papers 1949, 121, 556; Truman, Public Papers 1950, 129.

${ }^{271}$ U.S. Department of State, Foreign Relations 1947: Volume III, 35-45, 144.

${ }^{272}$ Roger Makins, interview by Theodore A. Wilson, transcript, 10 August 1970, Oral History Collection, Truman Library, Independence, MO, 12.

${ }^{273}$ Peter Hahn, 21.

${ }^{274}$ Louis, "American Anti-Colonialism," 404.

${ }^{275}$ Peter Hahn 18, 39, 51; Leffler, A Preponderance of Power, 113; Weiler, "British Labour and the Cold War," 70.

${ }^{276}$ Lind, 6; McCullough, 539-540; Isaacson, 387.

${ }^{277}$ Hamby, 390; Anderson, 142, 178-179.

${ }^{278}$ Reitzel, 200.

${ }^{279}$ Robertson, 98 .

${ }^{280}$ Dorpalen, 432.

${ }^{281}$ Reitzel, 201, 225.

${ }^{282}$ Leffler, A Preponderance of Power, 165.

${ }^{283}$ Bancroft, 23.

${ }^{284}$ Ibid.

${ }^{285}$ Leffler, A Preponderance of Power, 259.

${ }^{286}$ Truman, Public Papers 1950, 336. 
${ }^{287}$ Reitzel, 224-225; Robertson, 100.

${ }^{288}$ Reitzel, 226.

${ }^{289}$ LaFeber, The American Age, 520.

${ }^{290}$ McMahon, 64.

${ }^{291}$ Donovan, 252.

${ }^{292}$ Leffler, A Preponderance of Power, 166.

${ }^{293}$ Ferrell, American Diplomacy, 798-799.

${ }^{294}$ Kahin, 4.

${ }^{295}$ Gravel, 1-2; McMahon, 64.

${ }^{296}$ Leffler, A Preponderance of Power, 93.

${ }^{297}$ Gravel, 3 .

${ }^{298}$ Ibid.

${ }^{299}$ Truman, Years of Trial and Hope, 437.

${ }^{300}$ Leffler, A Preponderance of Power, 166.

${ }^{301}$ LaFeber, America, Russia, and the Cold War, 126.

${ }^{302}$ Acheson, Present at the Creation, 671.

${ }^{303}$ Ferrell, Harry S. Truman: A Life, 357; LaFeber, America, Russia, and the Cold War, 136; Spanier, 172.

${ }^{304}$ Truman, Public Papers 1950, 531.

${ }^{305}$ Gravel, 4 .

${ }^{306}$ Acheson, Present at the Creation, 553.

${ }^{307}$ McMahon, 71.

${ }^{308}$ Leffler, A Preponderance of Power, 166.

${ }^{309}$ LaFeber, The American Age, 520; Gravel, 32.

${ }^{310}$ Gravel, 54 .

${ }^{311}$ Ibid., 3.

${ }^{312}$ Acheson, Present at the Creation, 335.

${ }^{313}$ Acheson, Present at the Creation, 257, Gravel, 53. 
${ }^{314}$ Gravel, 6; Kahin, 36-37.

${ }^{315}$ Gravel, 53-55; Acheson, Present at the Creation, 335.

${ }^{316}$ Miscamble, 318-319; Gravel, 51, 53.

\section{CHAPTER V: CONCLUSION}

${ }^{1}$ Truman, Years of Trial and Hope, 239.

${ }^{2}$ Truman, Year of Decisions, 275. 


\section{BIBLIOGRAPHY}

\section{PRIMARY SOURCES}

\section{Memoirs}

Acheson, Dean. Present at the Creation: My Years in the State Department. New York: W.W. Norton \& Company, Inc., 1969.

Attlee, Clement. Twilight of Empire: Memoirs of Prime Minister Clement Attlee. comp.

Francis Williams. New York: A.S. Barnes and Co., 1960.

Forrestal, James. The Forrestal Diaries. ed. Walter Millis with collaboration of E. S. Duffield. New York: The Viking Press, 1951.

Truman, Harry S. Memoirs by Harry S. Truman Volume One: Year of Decisions. Garden City, NY: Doubleday and Company, 1955.

. Memoirs by Harry S. Truman Volume Two: Years of Trial and Hope. Garden City, NY: Doubleday and Company, 1956.

\section{Interviews}

Acheson, Dean. "Oral History Interview with Dean Acheson, Assistant Secretary of State, 1941-45; Under Secretary of State, 1945-47; and Secretary of State, 1949-53." Interview by Theodore A. Wilson and Richard D. McKinzie, transcript, 30 June 1971, Oral History Collection, Truman Library, Independence, MO.

Achilles, Theodore. "Oral History Interview with Theodore Achilles, Foreign Service Officer, U.S. Department of State, 1931-62." Interview by Richard D. McKinzie, transcript, 13 November and 18 December 1972, Oral History Collection, Truman Library, Independence, MO.

Andrews, Stanley. "Oral History Interview with Stanley Andrews, Chief of Food, Agriculture and Forestry Division of the American-British Control Group in Germany, 1948-49; Director, Office of Foreign Agricultural Relations, Department of Agriculture, 1949-51; and Director, Technical Cooperation Administration, Point IV 
Program, 1952-53." Interview by Richard D. McKinzie, transcript, 31 October 1970, Oral History Collection, Truman Library, Independence, MO.

Baker, George P. “Oral History Interview with George P. Baker, U.S. Member Transport and Communications Commission, United Nations, 1946-56; Chairman, Commission on Aero Research and Development Board, National Military Establishment, 194849." Interview by Richard D. McKinzie, transcript, 24 July 1974, Oral History Collection, Truman Library, Independence, MO.

Bancroft, Harding F. "Oral History Interview with Harding F. Bancroft, U.S. Deputy Representative to the United Nations Collective Measures Committee with personal rank of Minister, 1950-53." Interview by Richard D. McKinzie, transcript, 25 June 1974, Oral History Collection, Truman Library, Independence, MO.

Cady, John F. "Oral History Interview with John F. Cady, U. S. Department of State, Chief of the South Asian Section, Office of Near Eastern and African Affairs, 19451949." Interview by Richard D. McKinzie, transcript, 31 July 1974, Oral History Collection, Truman Library, Independence, MO.

Campbell, John C. "Oral History Interview with John C. Campbell, U.S. Department of State, Officer in Charge of Balkan Affairs, 1949-55." Interview by Richard D. McKinzie, transcript, 24 June 1974, Oral History Collection, Truman Library, Independence, MO.

Cohen, Edgar. "Oral History Interview with Sir Edgar Cohen, British Board of Trade, 1932-53; Chairman of United Nations Interim Coordinating Committee for International Commodity Arrangements, 1953-54." Interview by Theodore A. Wilson, transcript, 12 June 1970, Oral History Collection, Truman Library, Independence, MO.

Coppock, Joseph D. “Oral History Interview with Joseph D. Coppock, U.S. Department of State Economic Advisor on International Trade Policy, 1945-53; Member, U.S. delegation to the Economic and Social Council of the United Nations, 1946-52." Interview by Richard D. McKinzie, transcript, 29 July 1974, Oral History Collection, Truman Library, Independence, MO.

Dennison, Robert L. "Oral History Interview with Admiral Robert L. Dennison, Naval Aide to President Harry S. Truman, 1948-53; Commander in Chief of the Atlantic Command, Commander of the Atlantic Fleet, and Supreme Allied Commander, Atlantic, 1960-63." Interview by Jerry N. Hess, transcript, 2 November 1971, Oral History Collection, Truman Library, Independence, MO.

Ensminger, Douglas. "Oral History Interview with Douglas Ensminger, U.S. Department of Agricultural, including a period in the Office of Foreign Agricultural Relations, 1939-1951." Interview by Harry S. Taylor, transcript, 16 June and 7 July 1976, Oral History Collection, Truman Library, Independence, MO. 
Feeney, Joseph G. "Oral History Interview with Joseph G. Feeney, Legislative Assistant to the President, 1949-52; Administrative Assistant to the President, 1952-53." Interview by Jerry N. Hess, transcript, 20 September 1966, Oral History Collection, Truman Library, Independence, MO.

Fetter, Frank W. "Oral History Interview with Frank W. Fetter, U.S. Department of State, 1944-46." Interview by Richard D. McKinzie, transcript, 22 July 1974, Oral History Collection, Truman Library, Independence, MO.

Jones, John W. "Oral History Interview with John Wesley Jones, U. S. Department of State, First Secretary Rome Embassy, 1945-48; Embassy Counselor, Nanking, China, 1948-49; Embassy Counselor, Madrid, Spain, 1949-53." Interview by Richard D. McKinzie, transcript, 8 June 1974, Oral History Collection, Truman Library, Independence, MO.

Kenney, W. John "Oral History Interview with W. John Kenney, Under Secretary of Navy, 1947-49; Chief of Mission, England, 1949-50; Deputy Director for Mutual Security, 1952." Interview by Richard D. McKinzie and Theodore A. Wilson, transcript, 29 November 1971, Oral History Collection, Truman Library, Independence, MO.

Leddy, John M. "Oral History Interview with Ambassador John M. Leddy, U. S. Department of State, and participant in the negotiations to conclude the General Agreement on Tariffs and Trade and the International Trade Organization, 1945-58." Interview by Richard D. McKinzie, transcript, 15 June 1973, Oral History Collection, Truman Library, Independence, MO.

Makins, Roger. "Oral History Interview with Sir Roger Makins, British Assistant Under Secretary of State for Foreign Affairs, 1947-48; British Deputy Under Secretary of State, 1948-52; British Ambassador to the United States, 1952-56." Interview by Theodore A. Wilson, transcript, 10 August 1970, Oral History Collection, Truman Library, Independence, MO.

Marjolin, Robert. "Oral History Interview with Robert Marjolin, French Secretary General, Organization for European Economic Cooperation, 1948-55." Interview by Theodore A, Wilson, transcript, 2 July 1971, Oral History Collection, Truman Library, Independence, MO.

Markezinis, Spyros. "Oral History Interview with Spyros Markezinis, Greek Prime Minister, October-November 1973, Greek Minister for Coordination and Economic Planning, 1949-1954." Interview by Theodore A. Wilson, transcript, 22 July 1970, Oral History Collection, Truman Library, Independence, MO.

Martin, Edwin W. "Oral History Interview with Edwin W. Martin, U. S. Department of State Vice consul Leopoldville, Belgian Congo, 1944; Vice consul Peiping, China, 
1946-48; Vice consul Hankow, China, 1948-49; Consul Taipei, Formosa, 1949-50; Consul Rangoon, Burma, 1950-1951." Interview by Richard D. McKinzie, transcript, 3 June 1975, Oral History Collection, Truman Library, Independence, MO.

Mathews, Elbert G. "Oral History Interview with Ambassador Elbert G. Mathews, U. S. Department of State Assistant Chief, Division of South Asian Affairs, 1947-48; Chief, Division of South Asian Affairs, 1948-49; Director, Office of South Asian Affairs, 1950-1951; Consul General, Istanbul, 1951-52." Interview by Richard D. McKinzie, transcript, 13 June 1975, Oral History Collection, Truman Library, Independence, MO.

Matlock, Clifford C. "Oral History Interview with Clifford C. Matlock, U. S. Department of State, Economist and Political Officer, 1946-62." Interview by Richard D. McKinzie, transcript, 29 October 1973 and 6 June 1974, Oral History Collection, Truman Library, Independence, MO.

Nolting, Frederick. "Oral History Interview with Frederick Nolting, U. S. Department of State Assistant Chief of North European Affairs, 1948-49; Officer in Charge of SwissBenelux Affairs, 1949-1950; Coordinator, Air Programs for Far East, 1950; Member, U. S. Delegation to $6^{\text {th }}$ Session United Nations General Assembly, 1951; Assistant to Deputy Under Secretary of State, 1950-53." Interview by Richard D. McKinzie, transcript, 30 June 1975, Oral History Collection, Truman Library, Independence, MO.

Snyder, John W. "Oral History Interview with John W. Snyder, Secretary of the Treasury, 1946-53." Interview by Jerry N. Hess, transcript, 3 April 1968, Oral History Collection, Truman Library, Independence, MO.

Snyder, John W. "Oral History Interview with John W. Snyder, Secretary of the Treasury, 1946-53.” Interview by Jerry N. Hess, transcript, 15 January 1969, Oral History Collection, Truman Library, Independence, MO.

Stikker, Dirk U. "Oral History Interview with Dirk U. Stikker, Netherlands Minister of Foreign Affairs, 1948-52." Interview by Theodore A. Wilson, transcript, 14 July 1970, Oral History Collection, Truman Library, Independence, MO.

Trezise, Philip. "Oral History Interview with Philip Trezise, U. S. Department of State Deputy Director, Office Intelligence Research, Intelligence Activities, 1943-56." Interview by Richard D. McKinzie, transcript, 27 May 1975, Oral History Collection, Truman Library, Independence, MO.

Warren, George L. "Oral History Interview with George L. Warren, U. S. Representative to the General Council and Executive Committee, International Refugee Organization, 1948-52." Interview by Richard D. McKinzie, transcript, 10 November 1972, Oral History Collection, Truman Library, Independence, MO. 
Wilcox, Francis O. "Oral History Interview with Francis O. Wilcox, Chief of Staff, Senate Foreign Relations Committee, 1947-55." Interview by Donald A. Ritchie, transcript, 13 April 1984, Oral History Collection, Truman Library, Independence. MO.

Wilson, Evan M. "Oral History Interview with Evan M. Wilson, Second Secretary and Vice Consul and later First Secretary and Consul, Tehran, Iran, March 1947-June 1949." Interview by Richard D. McKinzie, transcript, 18 July 1975, Oral History Collection, Truman Library, Independence, MO.

\section{Unpublished Sources}

Abbot, W. Wright letter to President Harry S. Truman. 12 February 1947. President's Secretary's Files: Truman Papers, Truman Library, Independence, MO.

Acheson, Dean. Memorandum for the President. "Subject: de jure Recognition of the Governments of Israel and Transjordan." 27 January 1949, President's Secretary's Files: Truman Papers, Truman Library, Independence, MO.

Astreas, C. telegram to President Harry S. Truman. 15 October 1945. President's Secretary's Files: Truman Papers, Truman Library, Independence, MO.

Bengeri, K. R. letter to United Nations Secretary General. 3 June 1947. President's Secretary's Files: Truman Papers, Truman Library, Independence, MO.

Elwood, George O. letter to Mr. Harry S. Truman. 7 March 1946. President's Secretary's Files: Truman Papers, Truman Library, Independence, MO.

Faldecker, R. letter to the Honorable Harry S. Truman. 2 December 1951. President's Secretary's Files: Truman Papers, Truman Library, Independence, MO.

Gillette, Guy M. telegram to the President. 25 February 1947. President's Secretary's Files: Truman Papers, Truman Library, Independence, MO.

Grady, Henry telegram to the President. 28 June 1951. President's Secretary's Files: Truman Papers, Truman Library, Independence, MO.

Hannegan, Robert E. letter to the President. 14 November 1946. President's Secretary's Files: Truman Papers, Truman Library, Independence, MO.

Hassett, William D. letter to Mr. James H. Lewis. 25 November 1946. President's Secretary's Files: Truman Papers, Truman Library, Independence, MO.

Hassett, William D. letter to Mr. S. S. Larmon. 11 February 1947. President's Secretary's Files: Truman Papers, Truman Library, Independence, MO. 
Henderson. memorandum to Mr. McDermott. "Subject: Public Statement by President Truman in Connection with the Assassination of Mohandas Gandhi." 30 January 1948. President's Secretary's Files: Truman Papers, Truman Library, Independence. MO.

Hess, Jack telegram to the President. 3 September 1947. President's Secretary's Files: Truman Papers, Truman Library, Independence, MO.

Hopkins, William J. “Communiqué”. 9 January 1952. President's Secretary's Files: Truman Papers, Truman Library, Independence, MO.

Keplinger, Henry telegram to the President. 19 November 1951. President's Secretary's Files: Truman Papers, Truman Library, Independence, MO.

Kyprianos, Bishop letter to President Truman. 28 October 1950. President's Secretary's Files: Truman Papers, Truman Library, Independence, MO.

Lipsky, Louis telegram to the President. 22 July 1947. President's Secretary's Files: Truman Papers, Truman Library, Independence, MO.

Marshall, G.C. memorandum for the President. "Subject: Proposed Exchange of Ambassadors with Dominion of Pakistan." 17 July 1947. President's Secretary's Files: Truman Papers, Truman Library, Independence, MO.

McCroden, N. G. letter to Mr. Charles Ross. 15 October 1946. President's Secretary's Files: Truman Papers, Truman Library, Independence, MO.

McDermott, Michael J. memorandum to Charles G. Ross. "Draft Press Statement on the Establishment of the South Pacific Commission." 21 January 1948. President's Secretary's Files: Truman Papers, Truman Library, Independence, MO.

Michael, Archbishop telegram to the President. 12 October 1950. President's Secretary's Files: Truman Papers, Truman Library, Independence, MO.

Mossadegh, Mohammed letter to President Harry S. Truman. 10 November 1951. President's Secretary's Files: Truman Papers, Truman Library, Independence, MO.

Mulumba telegram to the President. 20 March 1950. President's Secretary's Files: Truman Papers, Truman Library, Independence, MO.

Murphy, Carl telegram to the President. 26 August 1947. President's Secretary's Files: African American, Truman Papers, Truman Library, Independence, MO.

Murray, James E. letter to President Harry S. Truman. 28 January 1952. President's Secretary's Files: Truman Papers, Truman Library, Independence, MO. 
Null, Eugene J. letter to President Harry S. Truman. 11 February 1947. President's Secretary's Files: Truman Papers, Truman Library, Independence, MO.

Pahlavi, M. R. letter to President Harry S. Truman. 24 August 1951. President's Secretary's Files: Truman Papers, Truman Library, Independence, MO.

Press Release. "Agreement announced with the United Kingdom with respect to the Supply of Scarce Materials." TD, apparently written by the President's staff in the White House. 18 January 1952. President's Secretary's Files: Truman Papers, Truman Library, Independence, MO.

Press Release. Statement by the President. TD, apparently written by the President's staff in the White House. 13 February 1947. President's Secretary's Files: Truman Papers, Truman Library, Independence, MO.

Roosevelt, Eleanor letter to President Harry S. Truman. 20 November 1945. President's Secretary's Files: Truman Papers, Truman Library, Independence, MO.

. letter to President Harry S. Truman. 17 April 1947. President's Secretary's Files: Truman Papers, Truman Library, Independence, MO.

. letter to President Harry S. Truman. 28 May 1950. President's Secretary's Files: Truman Papers, Truman Library, Independence, MO.

. letter to President Harry S. Truman. 14 December 1950. Official File:

Truman Papers, Truman Library, Independence, MO.

. letter to President Harry S. Truman. 6 May 1951. President's Secretary's

Files: Truman Papers, Truman Library, Independence, MO.

Short, Joseph letter to Mr. Ulric Nisbet. 11 December 1951. President's Secretary's Files: Truman Papers, Truman Library, Independence, MO.

Summers, D. B. letter to Senator Edwin C. Johnson. 30 July 1951. President's Secretary's Files: Truman Papers, Truman Library, Independence, MO.

Truman, Harry S. “Address at the San Francisco War Memorial Opera House." San Francisco, CA, 17 October 1950. President's Secretary's Files: Truman Papers. Truman Library, Independence, MO.

. "Address Opening the Meeting of the Foreign Ministers of the American Republics." Speech presented at the fourth meeting of Consultation of Ministers of Foreign Affairs of American States, Washington, D.C., 26 March 1951. President's Secretary's Files: Truman Papers, Truman Library, Independence, MO. 
. "Address to the National Council of Negro Women." Speech presented at the annual meeting of the National Council of Negro Women, Inc, Washington, D.C., 15 November 1949. President's Secretary's Files: Truman Papers, Truman Library, Independence, MO.

. "Excerpts from the First and Second Drafts of Truman's Memoirs, 1953(?)," TMs (photocopy), Truman Papers, Truman Library, Independence, MO.

. "Excerpts of a Conversation with Mr. Harris." n.d. transcript. Post Presidential Files Box 644: Truman Papers, Truman Library, Independence, MO.

. memorandum. "Subject: Special Rank Recommended for Charles W. Lewis, Jr., in Connection with Pakistan Ceremonies." 11 August 1947. President's Secretary's Files: Truman Papers, Truman Library, Independence, MO.

. "News Conference." Washington, D.C., 30 November 1950. President's Secretary's Files: Truman Papers, Truman Library, Independence, MO.

. "Remarks to a Group of Methodist Ministers." Washington, D.C., 7 February 1951. President's Secretary's Files: Truman Papers, Truman Library, Independence, MO.

. "Campaign Speech at Campagnone Memorial Common." Lawrence, MA, 17 October 1952. President's Secretary's Files: Truman Papers, Truman Library, Independence, MO.

Truman, Harry S. letter to Vice President of the United States Alban W. Barkley. 9 January 1952. President's Secretary's Files: Truman Papers, Truman Library, Independence, MO.

Truman, Harry S. letter to King Abdullah Ibn El Hussein of the Hashemite Kingdom of Jordan. 27 March 1951. President's Secretary's Files: Truman Papers, Truman Library, Independence, MO.

Truman, Harry S. letter to Eleanor Roosevelt. 2 October 1945. Eleanor Roosevelt Papers, Part II, 1945-1960, Roosevelt Library.

. letter to Eleanor Roosevelt. 7 May 1947. Eleanor Roosevelt Papers, Part II, 1945-1960, Roosevelt Library.

Truman, Harry S. letter to Senator Kenneth McKellar. 15 November 1945. President's Secretary's Files: Truman Papers, Truman Library, Independence, MO.

United Electrical Radio and Machine Workers of America letter to the President. 13 May 1946. President's Secretary's Files: Truman Papers, Truman Library, Independence, MO. 


\section{Books and Articles}

"An Open Letter from the Editors of LIFE to the People of England." Life Magazine. 12 October 1942, 34.

Belair, Felix, Jr. "Truman Aid Plan is Linked with ECA." New York Times. 29 January $1949,1$.

"Britain Defended on Colonial Rule." New York Times. 20 January 1945, 5.

Ferrell, Robert H. Off the Record: The Private Papers of Harry S. Truman. New York: Harper \& Row Publishers, 1980.

Krock, Arthur. "Political Debate Looms on U.S. Foreign Policy: Dewey Ends Wartime Truce by Taking a Public Position on Question of Italy's Former African Empire." New York Times. 22 August 1948. sec. E, 3.

Leviero, Anthony. "Truman for Truce in Palestine Fray, No Partition Bar." New York Times. 26 March 1948, 1.

Loewenheim, Francis L., Harold D. Langley, and Manfred Jonas, eds. Roosevelt and Churchill: Their Secret Wartime Correspondence. New York: Saturday Review Press and E.P. Dutton \& Co., Inc., 1975.

Matthews, Herbert L. "British Seek Funds to Assist Colonies." New York Times. 28 May 1947,8 .

Miller, Merle. Plain Speaking An Oral Biography of Harry S. Truman. Berkley, CA: Berkley Publishing Corporation, 1973.

"Point Four and the U.N." New York Times. 12 November 1949, 14.

Sulzberger, C.L. Strictly Personal and Confidential: The Letters Harry Truman Never Mailed. ed. Monte M. Poen. Boston: Little, Brown and Company, 1982.

\section{Government Publications}

National Security Council Report. NSC 68: United States Objectives and Programs for National Security (Declassified). President's Secretary's Files: Truman Papers, Truman Library, Independence, MO, 14 April 1950.

Truman, Harry S. Message to the Congress on the State of the Union and on the Budget for 1947. 14 January 1946. President's Secretary's Files: Truman Papers, Truman 
Library, Independence, MO.

, Public Papers of the Presidents of the United States: Containing the Public Messages, Speeches, and Statements of the President April 12 to December 31, 1945. Washington, D.C.: United States Government Printing Office, 1961.

, Public Papers of the Presidents of the United States: Containing the Public Messages, Speeches, and Statements of the President January 1 to December 31, 1946.

Washington, D.C.: United States Government Printing Office, 1962.

, Public Papers of the Presidents of the United States: Containing the Public

Messages, Speeches, and Statements of the President January 1 to December 31, 1947.

Washington, D.C.: United States Government Printing Office, 1963.

, Public Papers of the Presidents of the United States: Containing the Public

Messages, Speeches, and Statements of the President January 1 to December 31, 1948.

Washington, D.C.: United States Government Printing Office, 1964.

, Public Papers of the Presidents of the United States: Containing the Public

Messages, Speeches, and Statements of the President January 1 to December 31, 1949.

Washington, D.C.: United States Government Printing Office, 1964.

, Public Papers of the Presidents of the United States: Containing the Public Messages, Speeches, and Statements of the President January 1 to December 31, 1950.

Washington, D.C.: United States Government Printing Office, 1965.

,Public Papers of the Presidents of the United States: Containing the Public

Messages, Speeches, and Statements of the President January 1 to December 31, 1951.

Washington, D.C.: United States Government Printing Office, 1965.

, Public Papers of the Presidents of the United States: Containing the Public

Messages, Speeches, and Statements of the President January 1, 1952, to January 20,

1953. Washington, D.C.: United States Government Printing Office, 1965.

U.S. Central Intelligence Agency. Memorandum for the NSC Senior Staff Prepared to Supplement NIE-69, Probable Developments in North Africa: The Current Situation in North Africa (Declassified). President's Secretary's Files: Truman Papers, Truman Library, Independence, MO, 12 September 1952.

U.S. Central Intelligence Agency. National Intelligence Estimate (NIE-5): Indochina: 
Current Situation and Probable Developments (Declassified). President's Secretary's Files: Truman Papers, Truman Library, Independence, MO, 29 December 1950.

U.S. Central Intelligence Agency. National Intelligence Estimate (NIE-20): Resistance of Thailand, Burma, and Malaya to Communist Pressures in the Event of a Communist Victory in Indochina in 1951 (Declassified). President's Secretary's Files: Truman Papers, Truman Library, Independence, MO, 20 March 1951.

U.S. Central Intelligence Agency. National Intelligence Estimate (NIE-23): India's Position in the East-West Conflict (Declassified). President's Secretary's Files: Truman Papers, Truman Library, Independence MO, 4 September 1951.

U.S. Central Intelligence Agency. National Intelligence Estimate (NIE-26): Key Problems Affecting US Efforts to Strengthen the Near East (Declassified). President's Secretary's Files: Truman Papers, Truman Library, Independence, MO, 25 April 1951.

U.S. Central Intelligence Agency. National Intelligence Estimate (NIE-35/1): Probable Developments in Indochina through Mid-1952 (Declassified). President's Secretary's Files: Truman Papers, Truman Library, Independence, MO, 3 March 1952.

U.S. Central Intelligence Agency. National Intelligence Estimate (NIE-44): The British Position in Egypt (Declassified). President's Secretary's Files: Truman Papers, Truman Library, Independence, MO, 15 October 1951.

U.S. Central Intelligence Agency. National Intelligence Estimate (NIE-69): Probable Developments in North Africa (Declassified). President's Secretary's Files: Truman Papers, Truman Library, Independence, MO, 15 September 1952.

U.S. Central Intelligence Agency. National Intelligence Estimate (NIE-75/1): Probable Developments in Iran Through 1953 (Declassified). President's Secretary's Files: Truman Papers, Truman Library, Independence, MO, 9 January 1953.

U.S. Central Intelligence Agency. ORE 6-49: Rubber Supply Situation in the USSR (Declassified). President's Secretary's Files: Truman Papers, Truman Library, Independence, MO, 23 March 1949.

U.S. Central Intelligence Agency. ORE 25-48: The Break-up of the Colonial Empires and its Implications for US Security (Declassified). President's Secretary's Files: Truman Papers, Truman Library, Independence, MO, 3 September 1948.

U.S. Central Intelligence Agency. ORE 26-48: The Prospects for a United States of Indonesia (Declassified). President's Secretary's Files: Truman Papers, Truman Library, Independence, MO, 4 June 1948.

U.S. Central Intelligence Agency. ORE 27-50: South African Politics and U.S. Security 
(Declassified). President's Secretary's Files: Truman Papers, Truman Library, Independence, MO, 17 November 1950.

U.S. Central Intelligence Agency. ORE 33-49: Current Situation in Malaya (Declassified). President's Secretary's Files: Truman Papers, Truman Library, Independence, MO, 17 November 1949.

U.S. Central Intelligence Agency. ORE 39: Significant Considerations Regarding the Disposition of the Italian African Colonies (Declassified). President's Secretary's Files: Truman Papers, Truman Library, Independence, MO, 25 July 1947.

U.S. Central Intelligence Agency. ORE 40-49: Consequences of Dutch "Police Action" in Indonesia (Declassified). President's Secretary's Files: Truman Papers, Truman Library, Independence, MO, 27 January 1949.

U.S. Central Intelligence Agency. ORE 46-50: The Current Situation in British West Africa (Declassified). President's Secretary's Files: Truman Papers, Truman Library, Independence, MO, 29 September 1950.

U.S. Central Intelligence Agency. ORE 54: The Current Situation in Egypt (Declassified). President's Secretary's Files: Truman Papers, Truman Library, Independence, MO, 16 October 1947.

U.S. Central Intelligence Agency. ORE 61-48: The Probable Effects of Postponement of the Italian Colonies Question (Declassified). President's Secretary's Files: Truman Papers, Truman Library, Independence, MO, 2 November 1948.

U.S. Central Intelligence Agency. ORE 63: The Current Situation in French North Africa (Declassified). President's Secretary's Files: Truman Papers, Truman Library, Independence, MO, 18 December 1947.

U.S. Central Intelligence Agency. ORE 64: The Current Situation in France Declassified). President's Secretary's Files: Truman Papers, Truman Library, Independence, MO, 31 December 1947.

U.S. Central Intelligence Agency. ORE 79-49: US Security and the British Dollar Problem (Declassified). President's Secretary's Files: Truman Papers, Truman Library, Independence, MO, 31 August 1949.

U.S. Central Intelligence Agency. ORE 93-49: The Possibility of Britain's Abandonment of Overseas Military Commitments (Declassified). President's Secretary's Files: Truman Papers, Truman Library, Independence, MO, 23 December 1949.

U.S. Central Intelligence Agency. Special Estimate (SE-3): The Current Crisis in Iran (Declassified). President's Secretary's Files: Truman Papers, Truman Library, Independence, MO, 16 March 1951. 
U.S. Central Intelligence Agency. Special Estimate (SE-6): Current Developments in Iran (Declassified). President's Secretary's Files: Truman Papers, Truman Library, Independence, MO, 22 May 1951.

U.S. Central Intelligence Agency. Special Estimate (SE-23): Prospects for an Inclusive Middle East Defense Organization (Declassified). President's Secretary's Files: Truman Papers, Truman Library, Independence, MO, 17 March 1952.

U.S. Central Intelligence Agency. Special Estimate (SE-32): Consequences of Communist Control Over South Asia (Declassified). President's Secretary's Files: Truman Papers, Truman Library, Independence, MO, 3 October 1952.

U.S. Central Intelligence Agency. Special Report (SR-25): United Kingdom (Declassified). President's Secretary's Files: Truman Papers, Truman Library, Independence, MO, 7 December 1949.

U.S. Central Intelligence Agency. Special Report (SR-30): France (Declassified). President's Secretary's Files: Truman Papers, Truman Library, Independence, MO, 17 March 1950.

U.S. Central Intelligence Agency. Special Report (SR-31): Portugal (Declassified). President's Secretary's Files: Truman Papers, Truman Library, Independence, MO, 13 October 1949.

U.S. Central Intelligence Agency. Special Report (SR-48): Ireland (Declassified). President's Secretary's Files: Truman Papers, Truman Library, Independence, MO, 1 April 1949.

U.S. Department of State. Foreign Relations of the United States 1947: Volume III The British Commonwealth; Europe. Washington, D. C.: U.S. Government Printing Office, 1972.

U.S. Department of State. United States Policy and Diplomacy Regarding Vietnam, July 1954-September 1956 (Declassified). Washington, D. C.: U.S. Government Printing Office, June 1971.

\section{SECONDARY SOURCES}

\section{Unpublished Sources}

Anslover, Nicole L. "An Executive Echo Chamber: The Evolution of America's Vietnam Policy from Truman to Johnson." Ph.D. diss., University of Kansas, Lawrence, KS, 
2004.

Bills, Scott L. "Cold War Rimlands: The United States, NATO, and the Politics of Colonialism, 1945-1949.” Ph.D. diss., Kent State University, Kent, OH, 1981.

Colby, Thomas E. "From Indifference to Commitment: 1945-1951; America's Altered Perception of and Policy in the First Indochina War." M.A. thesis, Southern Connecticut State University, New Haven, CT, 2005.

Harris, Connie K. "Fulfilling the Covenant: The Wilsonian Influence on Harry Truman's Foreign Policy." Ph.D. diss., University of Nebraska, Lincoln, NB., 2002.

Lawrence, Mark A. "Selling Vietnam: The European Colonial Powers and the Origins of the American Commitment to Vietnam, 1944-1950." Ph.D. diss., Yale University, New Haven, CT, 1998.

Leff, Deborah. March 2006. Vietnam and the Presidency; How We Got In: The US, Asia, and Vietnam. Address to the first presidential libraries conference. John F. Kennedy Presidential Library and Museum Boston, MA. 10-11 March 2006.

McNay, John T. "Imperial Paradigm: Dean Acheson and American Foreign Policy." Ph.D. diss., Temple University, Philadelphia, PA, 1997.

McVety, Amanda K. "Truman's Point Four Program and the Creation of America's Modern Diplomatic Vision." Ph.D. diss., University of California, Los Angeles, CA, 2006.

\section{Published Sources}

Anderson, Terry H. The United States, Great Britain, and the Cold War: 1944-1947. Columbia, MO: University of Missouri Press, 1981.

Bailey, Thomas A. A Diplomatic History of the American People. Englewood Cliffs, NJ: Prentice Hall Inc., 1974.

Baritz, Loren. Backfire: A History of How American Culture Led Us Into Vietnam and Made Us Fight the Way We Did. 1985. Reprint, Baltimore: John Hopkins University Press, 1998.

Black, Allida M. Casting Her Own Shadow: Eleanor Roosevelt and the Shaping of Postwar Liberalism. New York: Columbia University Press, 1996.

Borstelmann, Thomas. Apartheid, Colonialism and the Cold War: The United States and Southern Africa, 1945-1952. Durham, NC: Duke University Press, 1990. 
Bullock, Alan. Ernest Bevin: Foreign Secretary 1945-1951. New York: W.W. Norton \& Company, Inc., 1983.

Dallek, Robert. Franklin D. Roosevelt and American Foreign Policy, 1932-1945. New York: Oxford University Press, 1979.

Donovan, Robert J. Conflict and Crisis: The Presidency of Harry S. Truman, 1945-1948. New York: W.W. Norton \& Company, Inc., 1977.

Dorpalen, Andreas. Europe in the 20 $0^{\text {th }}$ Century: A History. New York: The Macmillan Company, 1968.

Ferrell, Robert H. American Diplomacy: A History. 3d ed. New York: W.W. Norton \& Company, Inc., 1975. . Harry S. Truman: A Life. Columbia, MO: University of Missouri Press, 1994.

Foerster, Schuyler and Edward N. Wright, eds. American Defense Policy. $6^{\text {th }}$ ed. Baltimore: John Hopkins University Press, 1990.

Gaddis, John L. The Cold War: A New History. New York: Penguin Group, 2005. Strategies of Containment: A Critical Appraisal of Postwar American National Security Policy. Oxford: Oxford University Press, 1982.

Garraty, John A. and Peter Gay, eds. The Columbia History of the World. New York: Harper \& Row Publishers, 1972; reprint n.p., Dorset Press, 1981.

Gravel, Mike, introduction to The Pentagon Papers: The Defense Department History of United States Decisionmaking on Vietnam Volume I. The Senator Gravel ed. Boston: Beacon Press, 1971.

Hahn, Peter L. The United States, Great Britain, and Egypt, 1945-1956: Strategy and Diplomacy in the Early Cold War. Chapel Hill, NC: The University of North Carolina Press, 1991.

Hamby, Alonzo L. Man of the People: A Life of Harry S. Truman. New York: Oxford University Press, 1995.

Howard, Thomas C. and William D. Pederson, eds. Franklin D. Roosevelt and the Formation of the Modern World. Armonk, NY: M. E. Sharpe, Inc., 2003.

Isaacson, Walter and Evan Thomas. The Wise Men: Six Friends and the World They Made. New York: Touchstone, Simon \& Schuster Inc., 1988. 
Kahin, George M. INTERVENTION: How America Became Involved in Vietnam. New York: Alfred A. Knopf, 1986.

Kirkendall, Richard S. ed. The Truman Period As A Research Field: A Reappraisal, 1972. Columbia, MO: University of Missouri Press, 1974.

Kissinger, Henry A. Diplomacy. New York: Simon \& Schuster, 1994.

LaFeber, Walter. America, Russia, and the Cold War, 1945-2006. $10^{\text {th }}$ ed. Boston: McGraw-Hill, 2008.

The American Age: U.S. Foreign Policy at Home and Abroad 1750 to the Present. 2d ed. New York: W.W. Norton \& Company, 1994.

Lapping, Brian. End of Empire. New York: St. Martin's Press, 1985.

Lawrence, Mark A. and Fredrik Logevall. The First Vietnam War: Colonial Conflict and Cold War Crisis. Cambridge, MA: Harvard University Press, 2007.

Leffler, Melvyn P. A Preponderance of Power: National Security, the Truman Administration, and the Cold War. Stanford, CA: Stanford University Press, 1992.

Lind, Michael. Vietnam: The Necessary War, New York: Simon \& Schuster, 1999.

McCullough, David. Truman. New York: Simon and Schuster, 1992.

McIntyre, W. David. British Decolonization, 1946-1997: When, Why and How did the British Empire Fall?. New York: St. Martin's Press, 1998.

McMahon, Robert J, ed. Major Problems in the History of the Vietnam War: Documents and Essays. 3d ed. Boston: Houghton Mifflin Company, 2003.

Miscamble, Wilson D. From Roosevelt to Truman: Potsdam, Hiroshima, and the Cold War. Cambridge, MA: Cambridge University Press, 2007.

Murray, James N. Jr. The United Nations Trusteeship System. Urbana, IL: The University of Illinois Press 1957.

Paterson, Thomas G. ed. Major Problems in American Foreign Policy Volume II: Since 1914. 3d ed. Lexington, MA: D.C. Heath and Company, 1989.

Pirtle, Henry. comp. Kentucky Monitor: Complete Monitorial Ceremonies of the Blue Lodge. $17^{\text {th }}$ ed. Louisville, KY: Grand Lodge of Kentucky Free and Accepted Masons, 1979.

Reitzel, William, Morton A. Kaplan, and Constance G. Coblenz. United States Foreign 
Policy 1945-1955. Washington, D.C.: The Brookings Institution, 1956.

Robertson, Charles. International Politics Since World War II: A Short History. 2d ed.

New York: John Wiley \& Sons, Inc., 1975.

Schlesinger, Stephen C. Act of Creation: The Founding of the United Nations. Boulder, CO: Westview Press, 2003.

Spanier, John. American Foreign Policy Since World War II. $12^{\text {th }}$ ed. Washington, D.C.: Congressional Quarterly Inc., 1991.

Spero, Joan E. The Politics of International Economic Relations. $4^{\text {th }}$ ed. New York: St. Martin's Press, 1990.

Sulzberger, C.L. World War II. New York: McGraw-Hill Book Company, 1970.

Watson, Robert P., Michael J. Devine, and Robert J. Wolz, eds. The National Security Legacy of Harry S. Truman: Volume 1. Kirksville, MO: Truman State University Press, 2005.

Wesseling, H. L. The European Colonial Empires: 1815-1919. trans. Diane Webb. Harlow, England: Pearson Education Limited, 2004.

\section{Articles and Newspapers}

Boyle, Peter G. "Britain, America and the Transition from Economic to Military Assistance, 1948-51." Journal of Contemporary History 22, no. 3 (July 1978): 21538 .

Brewer, Susan A. review of Twisting the Lion's Tail: American Anglophobia between the World Wars, by John E. Moser. The American Historical Review 105, no. 3 (June 2000): 956-957.

Cain, Frank M. "Exporting the Cold War: British Responses to the USA's Establishment of COCOM, 1947-51." Journal of Contemporary History 29, no. 3 (July 1994): 501522.

Callahan, Raymond A. review of Business, Government, and the End of Empire: Malaya, 1942-1957, by Nicholas J. White. Albion: A Quarterly Journal Concerned with British Studies 30, no. 2 (Sumer 1998): 402-403.

Campbell, Thomas M. "Nationalism in America's UN Policy, 1944-1945." International Organization 27, no. 1 (Winter 1973): 25-44.

Chamberlin, William H. "The Cold War: A Balance Sheet." Russian Review 9, no. 2 
(April 1950): 79-86.

Cohen, Benjamin V. "The Impact of the United Nations on United States Foreign Policy." International Organization 5, no. 2 (May 1951): 274-281.

Cohen, Michael J. "The Genesis of the Anglo-American Committee on Palestine, November 1945: A Case Study in the Assertion of American Hegemony." The Historical Journal 22, no. 1 (March 1979): 185-207.

Cohen, Warren I. review of The Cold War on the Periphery: The United States, India, and Pakistan by Robert J. McMahon. Reviews in American History 22, no. 4 (December 1994): 705-710.

Crapol, Edward. "Some Reflections on the Historiography of the Cold War." The History Teacher 20, no. 2 (February 1987): 251-262.

Curtin, Philip. "The British Empire and Commonwealth in Recent Historiography." The American Historical Review 65, no. 1 (October 1959): 72-91.

Davis, Morris and Sidney Verba. "Party Affiliation and International Opinions in Britain and France, 1947-1956." The Public Opinion Quarterly 24, no. 4 (Winter 1960): 590604.

Dobson, Alan P. "Labour or Conservative: Does It Matter in Anglo-American Relations?" Journal of Contemporary History 25, no. 4 (October 1990): 387-407.

Dulles, Foster R. and Gerald E. Ridinger. "The Anti-Colonial Policies of Franklin D. Roosevelt." Political Science Quarterly 70, no. 1 (March 1955): 1-18.

Emerson, Rupert. "Colonialism." Journal of Contemporary History 4, no. 1 (January 1969): 3-16.

. reviews of People in Colonies, by Kumar Goshal; Mandates, Dependencies and Trusteeship, by H. Duncan Hall; and Colonial Policy and Practice, by J. S. Furnivall. World Politics 1, no. 4 (July 1949): 533-541.

Espy, Willard R. "Point Four and the Will to Reform." Far Eastern Survey 20, no. 5 (March 1951): 45-49.

Fordham, Benjamin O. "Economic Interests, Party, and Ideology in Early Cold War Era U.S. Foreign Policy.” International Organization 52, no. 2 (Spring 1998): 359-396.

Forsythe, David P. "Human Rights in U.S. Foreign Policy: Retrospect and Prospect." Political Science Quarterly 105, no. 3 (Autumn 1990): 435-454. . "The United Nations and Human Rights, 1945-1985." Political Science 
Quarterly 100, no. 2 (Summer 1985): 249-269.

Galey, Margaret E. "The Universal Declaration of Human Rights: The Role of Congress." PS: Political Science and Politics 31, no. 3 (September 1998): 524-529.

Glickman, David L. "The British Imperial Preference System." The Quarterly Journal of Economics 61, no. 3 (May 1947): 439-470.

Go, Julian. "Chains of Empire, Projects of State: Political Education and U.S. Colonial Rule in Puerto Rico and the Philippines." Comparative Studies in Society and History 42, no. 2 (April 2000): 333-362.

Hahn, Lorna H. "French North Africa: An American Problem." The Western Political Quarterly 8, no. 2 (June 1955): 186-198.

Hayes, Samuel P. Jr. "Statistics in the Point IV Program." The American Statistician 4, no. 1 (February 1950): 4-5.

Herring, George C. Jr. "The United States and British Bankruptcy, 1944-1945:

Responsibilities Deferred." Political Science Quarterly 86, no. 2 (June 1971): 260280.

Hess, Gary R. "Franklin Roosevelt and Indochina." The Journal of American History 59, no. 2 (September 1972): 353-368.

Horvath, Ronald J. "A Definition of Colonialism." Current Anthropology 13, no. 1 (February 1972): 45-57.

Ivie, Robert L. "Fire, Flood, and Red Fever: Motivating Metaphors of Global Emergency in the Truman Doctrine Speech." Presidential Studies Quarterly 29 (1999): 570-591.

Johnson, Douglas. review of Elementary Imperial Military Geography: General Characteristics of the Empire in Relation to Defence, by D. H. Cole. Geographical Review 15, no. 3 (July 1925): 506-507.

Johnson, Luke. "A Nation of Shopkeepers and World Beaters." Financial Times (London). 16 January 2008, 14.

Kennedy-Pipe, Caroline. "International History and International Relations Theory: A Dialogue beyond the Cold War." International Affairs 76, no. 4 (October 2000): 741754.

Kimball, Warren F. reviews of The United States and the Origins of the Cold War. 1941-1947, by John L. Gaddis; The Limits of Power: The World and United States Foreign Policy, 1945-1954, by Joyce Kolko and Gabriel Kolko; and The New Left and the Origins of the Cold War, by Robert J. Maddox. The American Historical Review 
79 , no. 4 (October 1974): 1119-1136.

Kirby, Dianne. "Divinely Sanctioned: The Anglo-American Cold War Alliance and the Defence of Western Civilization and Christianity, 1945-48." Journal of Contemporary History 35, no. 3 (July 2000): 385-412.

Kissinger, Henry A. "Reflections on a Partnership: British and American Attitudes to Postwar Foreign Policy." International Affairs 58, no. 4 (Autumn, 1982): 571-587.

Krozewski, Gerold. "Sterling, the 'Minor' Territories, and the End of Formal Empire, 1949-1958." The Economic History Review New Series, 46, no. 2 (May 1993): 239265.

Kruger, Daniel H. "Hobson, Lenin, and Schumpeter on Imperialism." Journal of the History of Ideas 16, no. 2 (April 1955): 252-259.

LaFeber, Walter. "Roosevelt, Churchill, and Indochina: 1942-45." The American Historical Review 80, no. 5 (Dec 1975): 1277-1295.

Leffler, Melvyn P. "The American Conception of National Security and the Beginnings of the Cold War, 1945-48." The American Historical Review 89, no. 2 (April 1984): 346-381.

."The Cold War: What Do "We Now Know?" The American Historical Review 104, no. 2 (April 1999): 501-524.

Leigh, Michael. "Is There A Revisionist Thesis on the Origins of the Cold War?" Political Science Quarterly 89, no. 1 (March 1974): 101-116.

Liu Xiaoyuan. "China and the Issue of Postwar Indochina in the Second World War." Modern Asian Studies 33, no. 2 (May 1999): 445-482.

Louis, William R. "American Anti-Colonialism and the Dissolution of the British Empire." International Affairs 61, no. 3 (Summer 1985): 395-420.

Lundestad, Guy. "Empire by Invitation? The United States and Western Europe, 19451952." Journal of Peace Research 23, no. 3 (September 1986): 263-277.

Mastny, Vojtech. reviews of Ambiguous Partnership: Britain and America, 1944-1947, by Robert M. Hathaway; From War to Cold War, 1942-48, by Roy Douglas; The United States, Great Britain, and the Cold War, 1944-1947, by Terry H. Anderson; The End of an Alliance: James F. Byrnes, Roosevelt, Truman, and the Origins of the Cold War, by Robert L. Messer; Witnesses to the Origins of the Cold War, by Thomas T. Hammond; Bitter Legacy: Polish-American Relations in the Wake of World War II, by Richard C. Lukas; American Intervention in Greece, 1943-1949, by Lawrence S. Wittner; Strategies of Containment: A Critical Appraisal of Postwar American 
National Security Policy, by John L. Gaddis; Stalin's American Policy: From Entente to Détente to Cold War, by William Taubman; and Soviet Foreign Policy Since World War II, by Joseph L. Nogee and Robert H. Donaldson. Slavic Review 42, no. 4 (Winter 1983): 662-668.

McMahon, Robert J. “Cultures of Empire." The Journal of American History 88, no. 3 (December 2001): 888-892.

. "United States Cold War Strategy in South Asia: Making a Military Commitment to Pakistan, 1947-1954." The Journal of American History 75, no. 3 (December 1988): 812-840.

Metz, Steven. "American Attitudes Toward Decolonization in Africa." Political Science Quarterly 99, no. 3 (Autumn 1984): 515-533.

Nelson, Anna K. "President Truman and the Evolution of the National Security Council." The Journal of American History 72, no. 2 (September 1985): 360-378.

Nwaubani, Ebere. "The United States and the Liquidation of European Colonial Rule in Tropical Africa, 1941-1963." Cahiers d'Études africaines 171 (2003): 505-551.

Orchard, John E. "ECA and the Dependent Territories." Geographical Review 41, no. 1 (January 1951): 66-87.

Reubens, Edwin P. “Asia and Truman's Fourth Point.” Far Eastern Survey 18, no. 6 (March 1949): 61-67.

Roark, James L. "American Black Leaders: the Response to Colonialism and the Cold War, 1943-1953.” African Historical Studies 4, no. 2 (1971): 253-270.

Rubin, Barry. “America and the Egyptian Revolution, 1950-1957." Political Science Quarterly 97, no. 1 (Spring 1982): 73-90.

Saiya, Nilay. "The U.S. Recognition of Israel: A Bureaucratic Politics Model Analysis." Concept On-line (2005), http://www.publications.villanova.edu/concept/2005.html (accessed 18 February 2008).

Sebrega, John J. "The Anticolonial Policies of Franklin D. Roosevelt: A Reappraisal." Political Science Quarterly 101, no. 1 (1986): 65-84.

Tang, James T. H. "From Empire Defence to Imperial Retreat: Britain's Postwar China Policy and the Decolonization of Hong Kong." Modern Asian Studies 28, no. 2 (May 1994): 317-337.

Thompson, J. K. “Abolition of Colonialism." The Journal of Negro History 37, no. 1 (January 1952): 81-89. 
Thompson, John A. reviews of $A$ Preponderance of Power: National Security, the Truman Administration, and the Cold War, by Melvyn P. Leffler; George F. Kennan and the Making of American Foreign Policy, 1947-1950, by Wilson D. Miscamble; Trapped by Success: The Eisenhower Administration and Vietnam, 1953-1961, by David L. Anderson; and General of the Army: George C. Marshall, Soldier and Statesman, by Ed Cray. Historical Journal 37, no. 3 (September 1994): 745-755.

Thorner, Alice. "White Paper on Burma." Far Eastern Survey 14, no. 11 (June 1945): 145.

Von Albertini, Rudolf. "The Impact of Two World Wars on the Decline of Colonialism." Journal of Contemporary History 4, no. 1, (January 1969): 17-35.

Warburg, James P. "Cold War Tragedy." The Western Political Quarterly 7, no. 3 (September 1954): 325-345.

Ward, Geoffrey C. review of ELEANOR AND HARRY: The Correspondence of Eleanor Roosevelt and Harry S. Truman, ed. Steven Neal. New York Times. 25 August 2002, 9.

Ward, Jeremy K. "Winston Churchill and the 'Iron Curtain' Speech." The History Teacher 1, no. 2 (January 1968): 15-13, 57-63.

Warner, Geoffrey. "The United States and Vietnam 1945-65: Part I: 1945-54." International Affairs 48, no. 3 (July 1972): 379-394.

Watt, D. C. "Restrictions on Research: The Fifty-Year Rule and British Foreign Policy." International Affairs 41, no. 1 (January 1965): 89-95.

Webster, Wendy. "There'll Always Be an England": Representations of Colonial Wars and Immigration, 1948-1968." The Journal of British Studies 40, no. 4 (October 2001) : 557-584.

Weiler, Peter. "British Labour and the Cold War: The Foreign Policy of the Labour Governments, 1945-1951." The Journal of British Studies 26, no. 1 (January 1987): 54-82. 


\section{CURRICULUM VITAE}

NAME: $\quad$ Timothy J. Pifer

ADDRESS: $\quad 4712$ Razor Creek Way

Louisville, KY 40299

DOB: $\quad$ Wheeling, West Virginia - April 19, 1957

EDUCATION

\& TRAINING: $\quad$ BS., Criminal Justice

West Virginia State College

1975-79

M.Ed., Curriculum and Instruction

National-Louis University

1991-92

PROFESSIONAL SOCIETIES: Phi Alpha Theta History Honor Society 